Portland State University

PDXScholar

Winter 3-5-2018

\title{
Glacier Inventories and Change in Glacier National Park
}

Melissa Carrie Brett

Portland State University

Follow this and additional works at: https://pdxscholar.library.pdx.edu/open_access_etds

Part of the Geography Commons, and the Geology Commons Let us know how access to this document benefits you.

\section{Recommended Citation}

Brett, Melissa Carrie, "Glacier Inventories and Change in Glacier National Park" (2018). Dissertations and Theses. Paper 4348.

https://doi.org/10.15760/etd. 6241

This Thesis is brought to you for free and open access. It has been accepted for inclusion in Dissertations and Theses by an authorized administrator of PDXScholar. Please contact us if we can make this document more accessible: pdxscholar@pdx.edu. 
Glacier Inventories and Change in Glacier National Park

by

Melissa Carrie Brett

A thesis submitted in partial fulfillment of the requirements for the degree of

\author{
Master of Science \\ in \\ Geology
}

Thesis Committee:

Andrew G. Fountain, Chair John Bershaw Adam Booth

Portland State University

2018 
Abstract

Glacier National Park, in northwestern Montana, is a unique and aweinspiring national treasure that is often used by the media and public-at-large as a window into the effects of climate change. An updated inventory of glaciers and perennial snowfields (G\&PS) in the Park, along with an assessment of their change over time, is essential to understanding the role that glaciers are playing in the environment of this Park. I compiled nine inventories between 1966 and 2015, to assess area changes of G\&PS. Over that 49-year period, total area changed by nearly $-34 \pm 11 \%$ between 1966 and 2015 . Volume change, determined from changes in surface topography for nine glaciers, totaling 8.61 $\mathrm{km}^{2}$ in area, was $+0.142 \pm 0.02 \mathrm{~km}^{3}$, a specific volume loss of $-16.3 \pm 2.5 \mathrm{~m}$. Extrapolating to all G\&PS in the Park in 1966 yields a park-wide loss of $-0.660 \pm$ $0.099 \mathrm{~km}^{3}$. G\&PS have been receding in the Park due to warming air temperatures rather than changes in precipitation, which has not changed significantly. Since 1900, air temperatures in Glacier National Park have warmed by $+1.3 \mathrm{C}^{\circ}$, compared to $+0.9 \mathrm{C}^{\circ}$ globally. Spatially, G\&PS at lower elevations and on steeper slopes lost relatively more area than other G\&PS. 


\section{Acknowledgements}

I would like to start by thanking Dr. Andrew G. Fountain for his patience and guidance during these two and a half years. It has been an honor and a privilege to work with you, and I am thankful for the chance to learn from the best! If I live a thousand years, I will still be unable to adequately thank you for sending me out into the world on the Wildest Dreamers Dream!

I would also like to thank Heather Miller, for taking a chance on our life together, and coming all this way to be supportive. You are steady like a mountain, and a truly strong and graceful warrior of this world! I am thankful that I know you, and proud to call you my partner in this life. Thanks for always holding the ladder...

Thank you to Ginger Eure, whose encouragement and words of wisdom have not failed me all these years. Your love and bravery have given me the courage to Go Boldly, and reach the summits of my own mind.

Thank you to my friends and family! Every one of you has brought light and love into my life! I will always be thankful for your encouragement and support throughout my adventures and academic endeavors!

Last, but not least, thank you to the USGS Western Mountain Initiative and Portland State University, for your generous funding. Without your assistance, none of this would have been possible. Thank you for your guidance and support during this time! 
Table of Contents

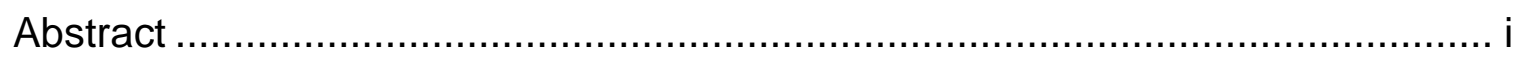

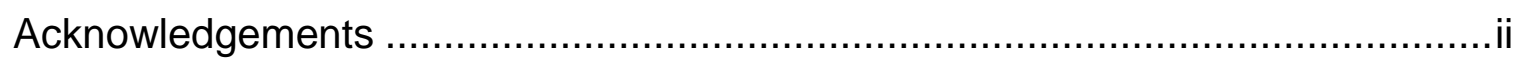

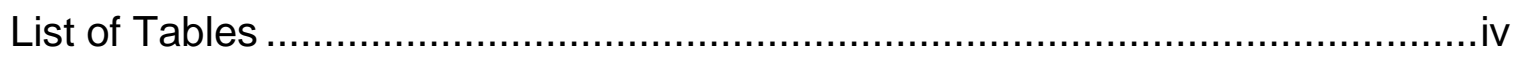

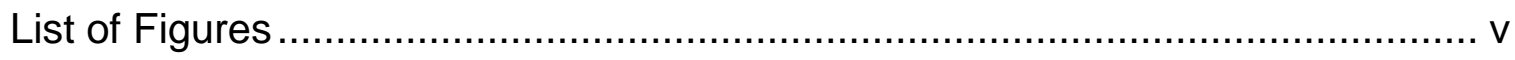

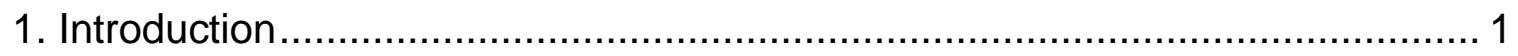

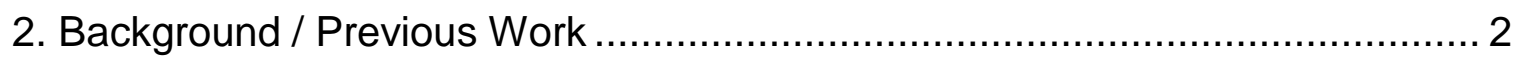

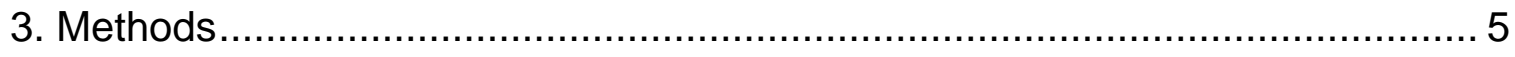

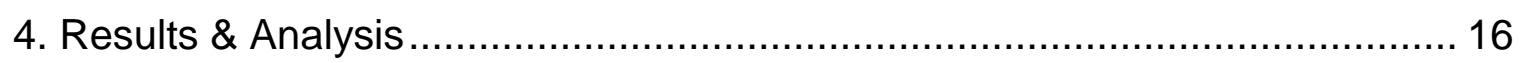

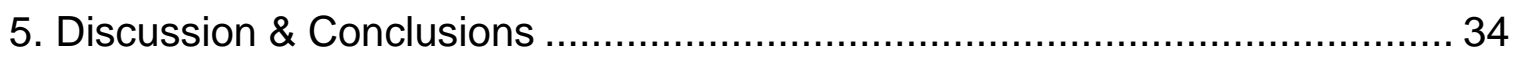

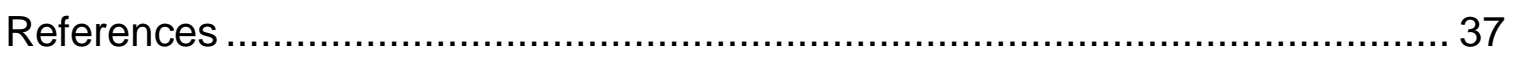

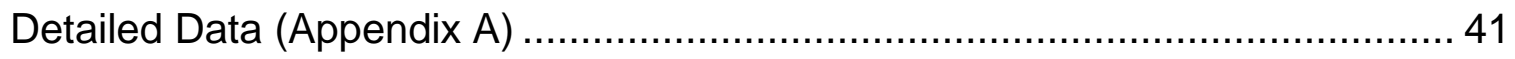

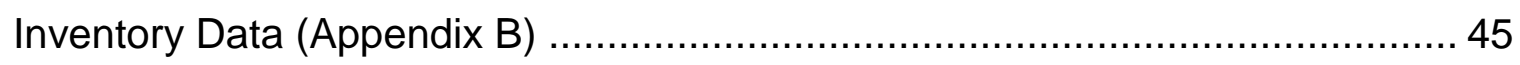




\section{List of Tables}

Table 1. Year and imagery source for the nine inventories compiled in this study. DOQ means digital orthoquadrangle, USGS means United State Geological Survey, USDA NAIP is the United States Department of Agriculture National Aerial Imagery Program. WorldView I is satellite imagery made available by Digital Globe Inc. Resolution is the spatial resolution in meters

Table 2. Number of all features in each inventory. G\&PS is glaciers and perennial snowfields; Not perennial is the number of features that are no longer perennial in each inventory; No imagery is the number of G\&PS for which no imagery was available

Table 3. Estimated total G\&PS area for each inventory. The complete inventories of 1966 and 2005 are in bold.

Table 4. Area characteristics of 100 G\&PS across all inventories. U\% is the percent uncertainty for total area in each inventory

Table 5. Volume change between 1966 and 2015 for all glaciers surveyed by lidar, compared to those estimated by the area-volume scaling relationship. DEM Vol means digital elevation model volume change, and represents the topographic method for estimating volume change. A/V Vol means area-volume volume change, using and the area-volume scaling method. For total, the volume calulatins are summed, and the specific volume changes are averaged. .28

Table 6. Pearson and Spearman correlation statistics for fractional area change of glaciers and perennial snowfields (G\&PS) relative to their topographic characteristics in 1966 and climate over the period 1966 to 2015. West and East are the fractional area change of G\&PS on either side of the continental divide. Large glaciers are those that are $\geq 0.1 \mathrm{~km}^{2}$. Correlations $(p<0.05)$ are reported in bold. 


\section{List of Figures}

Figure 1: Map showing the location of Glacier National Park and the distribution of glaciers and perennial snowfields (dark gray) within the Park boundaries. Data was derived from the US Geological Survey 1:24,000 scale topographic maps

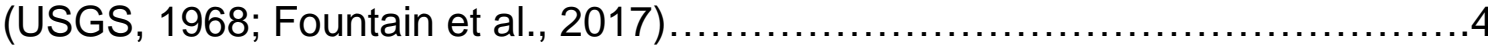

Figure 2. World View I satellite imagery (https://evwhs.digitalglobe.com) captured on 9/12/2015, showing evidence of ice movement in the form of crevasses

Figure 3. Topographic characteristics of the glaciers and perennial snowfields (G\&PS) from 1966. The black bars correspond to the number of G\&PS, and the gray bars represent the area in $\mathrm{km}^{2}$. A. The number of G\&PS per area, where the inset represents all data smaller than $0.2 \mathrm{~km}^{2}$. B. The number and area of G\&PS as a function of slope. $\mathrm{C}$. Aspect, where the radius represents the number of G\&PS facing that direction, in increments of 5. D. The number and area of G\&PS as a function of elevation. Bins are defined by their maximum elevation, area, or slope. For example, the slope bin 30 includes all slopes $>20$ and $\leq 30 \ldots \ldots \ldots \ldots 17$

Figure 4. Fractional area change for all G\&PS between 1966 and 2005. Fractional area change is the area change divided by the original area 19

Figure 5. The distribution of glacier and perennial snowfield (G\&PS) areas for the set of 100 G\&PS across all inventories. The vertical axis is the number of G\&PS, and the horizontal axis is the area in log scale. Bins are defined by their maximum area. For example, the slope bin 0.01 includes all areas $>0$ and $\leq 0.01$

Figure 6. Map showing the location of the six glaciers that have 1850 outlines. The black polygons are expanded to show location, and are not to scale........24

Figure 7. Area change of six glaciers with long-term observations. The oldest area $\sim 1850$ (LIA), based on mapped moraines, and really represent a period between about 1840-1960. No uncertainty is available for data between 1850 and 1960. Fractional area change is the measured area divided by the original area in $\sim 1850$

Figure 8. Elevation change of Sperry Glacier. On the left is the 2015 WorldView Satellite image captured on 9/12/15 (Digital Globe). On the right, the base hillshade is created from the 2015 LiDAR. The solid black line is the boundary of the glacier in 1966. The dashed black line is the boundary in 2015 
Figure 9. Fractional area change and regional average summer temperature

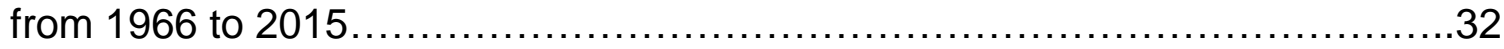




\section{Introduction}

Alpine glaciers are sensitive to changes in climate, and are important indicators of global and regional climate change (Roe et al., 2017; Oerlemans, 2005). The loss of glaciers worldwide is of concern due to their contribution to global sea level rise (Meier et al., 2007; IPCC, 2014). On a regional scale, alpine glaciers are significant contributors to late-summer stream runoff when the previous year's winter snowpack has melted (Fountain and Walder, 1998; Moore, et al., 2009). The availability of water during the drier and warmer months from glaciated watersheds makes runoff more hydrologically stable than watersheds without glaciers (Fountain and Tangborn, 1985). The loss of these stores of water could have a significant impact on high alpine ecology, agriculture, and power supplies (Tangborn et al., 1990).

Perennial snow and ice in Glacier National Park (GNP) are of interest because of their contribution to stream runoff during dry months and drought conditions, and their change has the potential to affect aquatic habitat and the wildlife that depend on it (Clark and Fagre, 2017; Hall and Fagre, 2003). Therefore, a current and thorough inventory of glaciers and perennial snowfields (G\&PS) in the Park will contribute to the assessment of global and regional glacier change, and are important to understanding the impact of climate change on ecosystem and hydrologic processes. This report provides a comprehensive digital inventory of glaciers and perennial snowfields, assesses area and volume change, and investigates the climate drivers forcing these changes. 


\section{Background / Previous Work}

Glacier National Park is located in the northwest corner of Montana, along the northern Rocky Mountains (Figure 1). The geology is primarily Cretaceous sedimentary rock layers, overlain by Precambrian sedimentary rocks as a result of the Lewis Overthrust fault (Alt and Hyndman, 1986; Bekker, 2005). The continental divide runs northwest-southeast through the heart of the Park, splitting it into two distinct climates. The western side of the park has greater annual and seasonal precipitation, influenced by moisture from the Pacific Ocean, whereas the eastern side is drier and windier, influenced by intrusions of cold Arctic air (Finklin, 1986). In the last $\sim 50$ years, air temperature in the region has risen by $\sim 1.3 \mathrm{C}^{\circ}$ (Pederson et al., 2010) compared to the global increase of $0.9 \mathrm{C}^{\circ}$ (IPCC, 2014). On average, temperatures in the western part of the Park are $\sim 0.25 \mathrm{C}^{\circ}$ warmer than in the east. Annual snowpack depth across the Park averages $6 \mathrm{~m}$ each winter, with the majority accumulating at the highest cirques and in the west (Klasner et al., 2002). The snow melts largely by early summer, and the late season streamflow is sustained by glacier melt (Fountain and Tangborn, 1985). The increasing frequency of drought conditions and rising average temperatures in the region has had an impact on glaciers at high elevation (Pederson et al., 2006).

Efforts to inventory glaciers globally have included many regions around the world, including the Himalayas (Mool et al., 2001), The Middle East and 
Africa (Williams, Jr., and Ferringno, 2005), Europe (Fischer et al., 2014), and the American West (Fountain et al., 2017). The glacier inventories of the American West include region-wide inventories for eight states, but do not include Montana, or Glacier National Park. Early glacier inventories for the Park were limited to the largest glaciers, often named, and do not account for all G\&PS, nor do those inventories span the temporal range of available imagery for the region.

The first glacier outlines in GNP were depicted on topographic maps created by the US Geological Survey (USGS) between 1900 and 1904, but they did not include all glaciers in the Park (Dightman and Beatty, 1952). The first comprehensive study of the Park's glaciers was completed between 1911 1913 , and estimated about 90 glaciers ranging in size from $0.01 \mathrm{~km}^{2}$ to $7.5 \mathrm{~km}^{2}$ (Alden, 1914). Many of the named glaciers were measured at that time, and a few have since split into two or more distinct glaciers since then. For example, Grinnell and Salamander glaciers were considered a single glacier prior to 1941. Blackfoot Glacier was identified and named in 1911, but split into two glaciers by 1939, now named Blackfoot and Jackson (Dyson, 1941). Glacier monitoring efforts in the region began in the mid 1930's, and focused on the named glaciers. Initially, the termini of Grinnell, Sperry and Jackson glaciers were mapped to track recession and advance (Carrara and McGimsey, 1988). Results from these early studies showed a loss of nearly $50 \%$ of the area of the named glaciers between 1902 and 1950 (Dightman and Beatty, 1952). The most comprehensive glacier inventory for the Park is based on the 1:24,000 topographic maps 
compiled by the USGS (Fountain et al, 2007, 2017). Digital outlines and topography from the National Elevation Dataset ( 10m) digital elevation models, derived from the maps, defined all G\&PS in the continental US. For Glacier National Park, the maps were compiled from aerial photography flown in 1963 (2\% of the G\&PS) and 1966 (98\%). Although the inventory is comprised of imagery from 1963 and 1966, the vast majority are from 1966, so for simplicity I will refer to the inventory as 1966 .

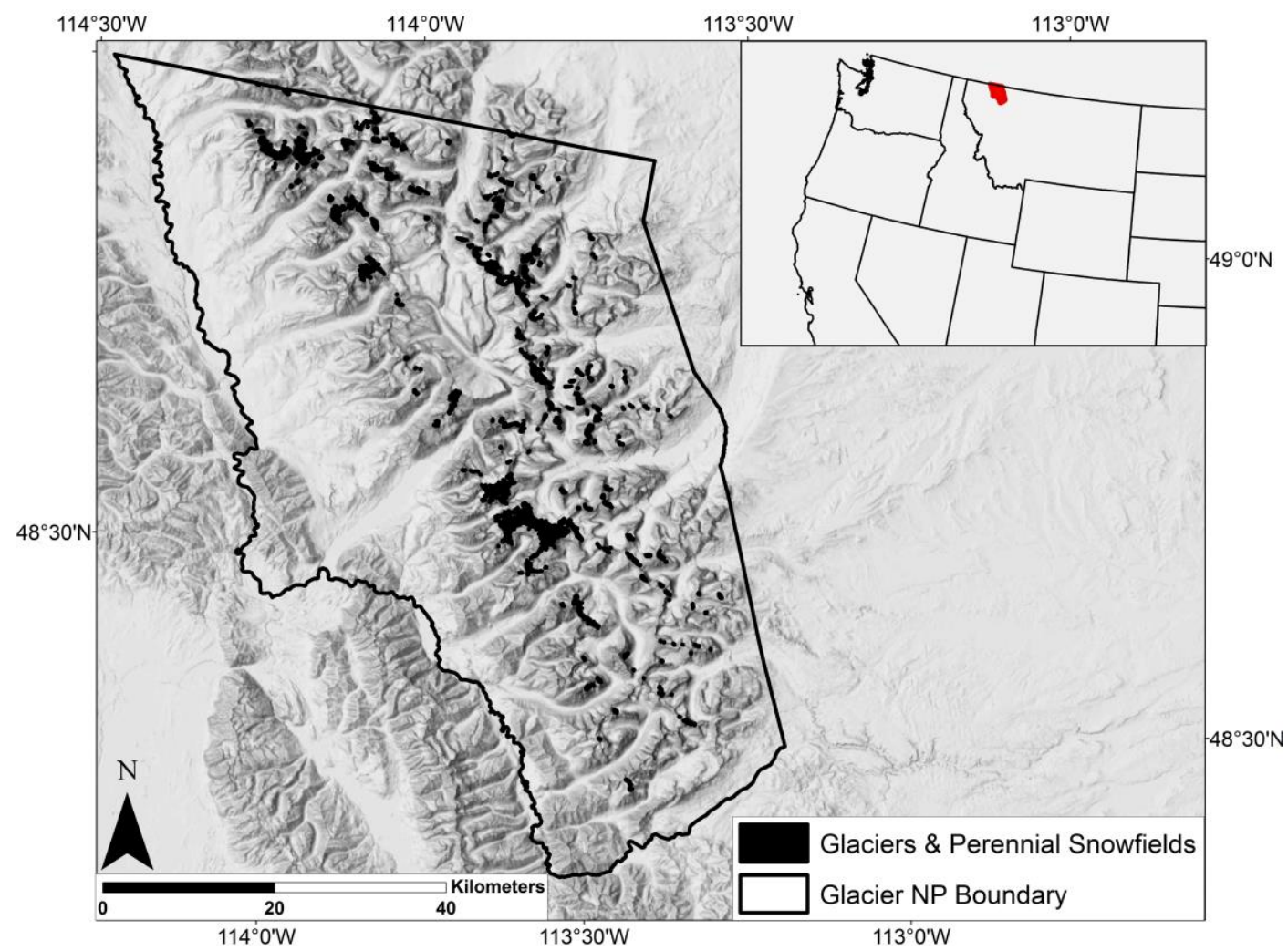

Figure 1: Map showing the location of Glacier National Park and the distribution of glaciers and perennial snowfields (dark gray) within the Park boundaries. Data was derived from the US Geological Survey 1:24,000 scale topographic maps (USGS, 1968; Fountain et al., 2017). 


\section{Methods}

To update the extent of the G\&PS, the 1966 inventory was used as a guide. Given the detail of the 1966 inventory and its error of inclusion (Fountain et al., 2017), it is unlikely that any G\&PS were missed. The outline of each G\&PS was superimposed on newer aerial photographs and satellite imagery, and checked for the presence of snow and ice. Aerial photographs and digital orthophotograph quadrangles (DOQ) were acquired from USGS Earth Explorer (https://earthexplorer.usgs.gov) and the National Agricultural Imagery Program (NAIP; https://lta.cr.usgs.gov/NAIP). Satellite images were downloaded from Digital Globe (https://evwhs.digitalglobe.com), or from the Polar Geospatial Center (https://www.pgc.umn.edu). G\&PS outlines were digitized using ArcMap 10.4.1 (ESRI, 2017) and Google Earth Pro 6.2, at a scale of 1:2000, which is a compromise between feature detail and digitizing efficiency (Fountain, 2017). The timing of imagery aquisition was limited to mid-July through mid-September to best reveal the glacier perimeter by minimizing the potential for seasonal snow cover. Overall, the imagery was good. The type, source, and resolution are listed in Table 1. 
Table 1. Year and imagery source for the nine inventories compiled in this study. DOQ means digital orthoquadrangle, USGS means United State Geological Survey, USDA NAIP is the United States Department of Agriculture National Aerial Imagery Program. WorldView I is satellite imagery made available by Digital Globe Inc. Resolution is the spatial resolution in meters.

\begin{tabular}{rrrr}
\hline Year & Type & Source & Resolution \\
\hline 1966 & Aerial Photos & USGS & $2.0 \mathrm{~m}$ \\
1979 & Aerial Photos & USGS & $2.0 \mathrm{~m}$ \\
1991 & DOQ's & USDA NAIP & $1.0 \mathrm{~m}$ \\
1995 & DOQ's & USDA NAIP & $1.0 \mathrm{~m}$ \\
1998 & Aerial Photos & USGS & $1.0 \mathrm{~m}$ \\
2003 & DOQ's & USDA NAIP & $1.0 \mathrm{~m}$ \\
2005 & DOQ's & USDA NAIP & $1.0 \mathrm{~m}$ \\
2013 & DOQ's & USDA NAIP & $1.0 \mathrm{~m}$ \\
2015 & Satellite Image & WorldView I & $0.5 \mathrm{~m}$
\end{tabular}

I assume all features found in the 1966 inventory to have been perennial up to that time. This is a conservative assumption that probably includes some seasonal snow patches. To discriminate between seasonal and perennial features, I used the approach from DeVisser and Fountain (2015). First, any snow and ice feature in the imagery that was not found in the first inventory (1966) was considered to be seasonal, and not outlined. Second, any 1966 feature that was absent from the inventory immediately following was considered to have disappeared. This is a conservative assumption, implying that the cartographer mistook a seasonal snow patch for a perennial feature. Assessing "perennial" from one-time imagery is nearly impossible. Third, any 1966 feature found in the inventory following, it was considered perennial. If subsequently absent or episodically reappearing, it was considered disappeared (seasonal).

Perennial features were further partitioned into glaciers versus perennial snowfields. A glacier is defined as a perennial mass of snow and ice that moves (Cuffey et al, 2010). To visually determine ice movement, I inspected all G\&PS 
using the aerial and satellite imagery used to digitize their outlines. The presence of crevasses was sufficient evidence to indicate ice movement (Figure 2). I also used a shear stress threshold (Basagic and Fountain 2011, Fountain et al 2017). Only the 1966 inventory includes these calculations because it is the only year where a digital elevation model (DEM) exists to extract topographic values for the entire dataset. Nominally, glacier movement occurs when its basal shear stress exceeds the critical shear stress of ice, $\sim 10^{5} \mathrm{~Pa}$ (Cuffey and Paterson, 2010). The basal shear stress is given by

$$
\tau_{b}=\rho_{i} g h \sin \gamma
$$

where $\rho_{i}$ is the density of ice $\left(900 \mathrm{~kg} \mathrm{~m}^{-1}\right), g$ is the acceleration due to gravity $\left(9.81 \mathrm{~m} \mathrm{~s}^{-2}\right), h$ is the thickness of the ice $(\mathrm{m})$, and $\gamma$ is the slope of the ice surface (radians). A density of ice less than the theoretical maximum is used to account for air bubbles in the ice. Ice thicknesses of the G\&PS are unknown, but can be estimated. A scaling relation exists between glacier area and volume (Chen \& Ohmura,1990; Bahr \& Meier 1997),

$$
V=\alpha A^{\beta}
$$

where, $V$ is glacier volume, $\alpha$ and $\beta$ are constants, and $A$ is the glacier area. Dividing equation (2) by the area, $A$ yields

$$
<h>=\alpha A^{\beta-1}
$$

where $\langle h\rangle$ is the average glacier thickness. To compensate for an average value of thickness, which is an underestimate for some places on the glacier and therefore underestimates shear stress. I used the maximum slope within each 
features outline. The constants have been derived empirically (Chen and Ohmura,1990, Driedger and Kennard, 1984) and theoretically (Bahr \& Meier, 1997). I used the subset of empirical constants from Chen \& Ohmura (1990) "Cascade $\&$ others" ( $\alpha$ of 30.835 and $\beta$ of 1.405), and the "Cascade, small glaciers" ( $\alpha$ of 21.346 and $\beta$ of 1.145). These constants were used because they best fit other studies in the continental US (Basagic and Fountain, 2011; Fountain et al 2017; and Oschlager, 2015). 


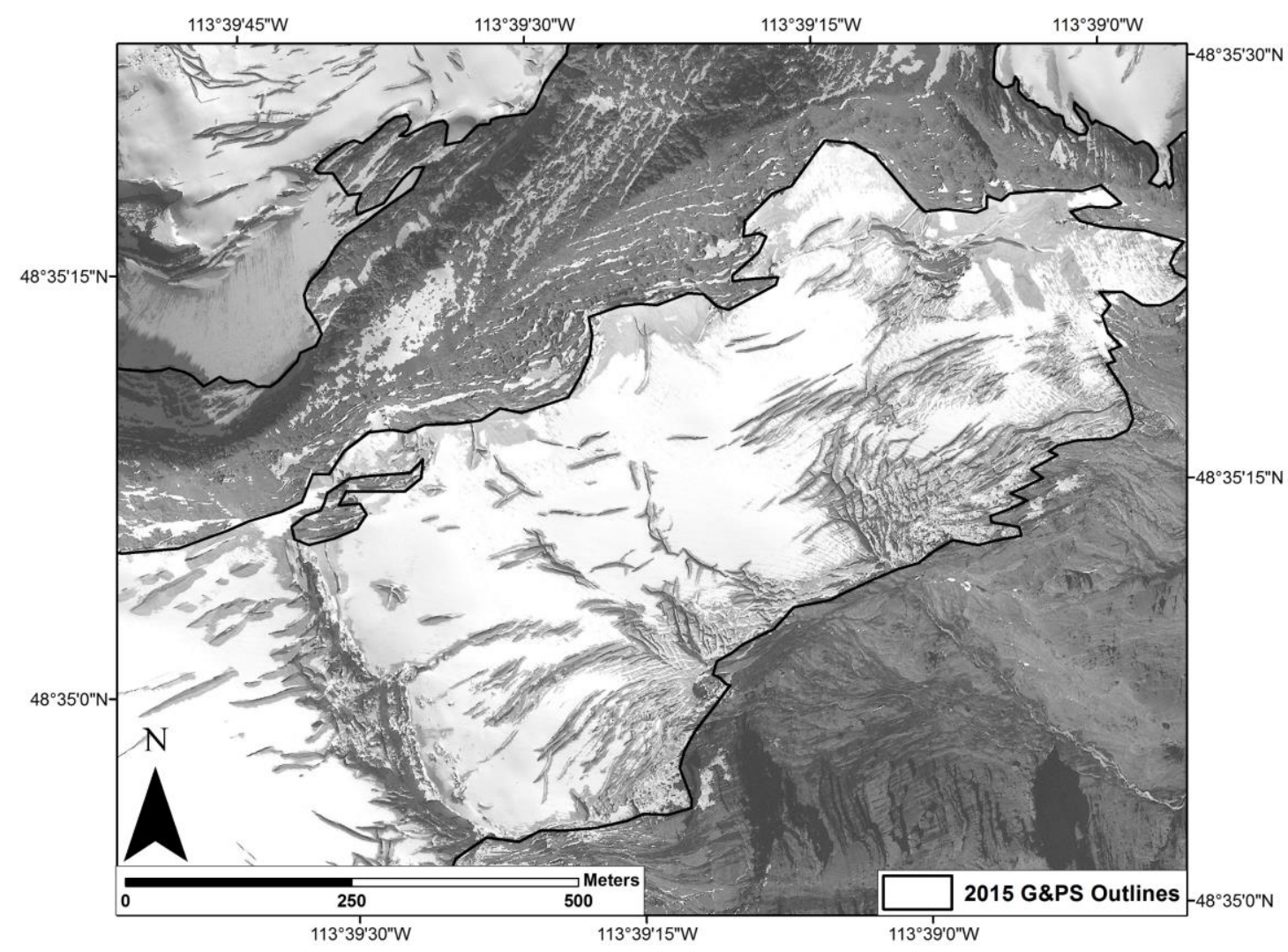

Figure 2. World View I satellite imagery (https://evwhs.digitalglobe.com) captured on $9 / 12 / 2015$, showing evidence of ice movement in the form of crevasses.

To assess area change over time, the area of each individual G\&PS in each inventory was compared across inventories. In addition to park-wide inventories, six of the largest glaciers are examined separately because they have been studied extensively in the past and provide insight on long-term changes. These glacier outlines were reconstructed from historic maps, groundbased photographs, and geomorphological evidence (Key et al., 2002). The earliest outlines date to the Little Ice Age (LIA) and are based on mapped 
moraines. Although Key et al (2002) tagged the LIA outlines as 1850, it is probably more accurate to say that they formed between 1840 and 1860 (Carrara, 1981).

Uncertainty

Uncertainty is introduced when defining the boundary of the G\&PS, and are based on the georeferencing, digitizing, and interpretation uncertainty (DeBeer and Sharp, 2007, Fountain, 2017). The area uncertainty $U$ is calculated as the root sum of squares of digitizing $\left(D_{u}\right)$, interpretation $\left(I_{u}\right)$, and positional $\left(P_{u}\right)$ uncertainties (DeVisser and Fountain, 2015),

$$
U=\sqrt{D_{u}{ }^{2}+I_{u}{ }^{2}+P_{u}{ }^{2}}
$$

$D_{u}$ is the uncertainty introduced by the difference, typically small, between where the outline is drawn, and the true boundary under ideal conditions. Following Hoffman et al (2007) who adopted Ghilani (2000), this uncertainty can be estimated from,

$$
D_{u}=d_{u} \sqrt{2 A}
$$

where, $d_{u}$ is the linear distance between the digitized outline and the true edge of a feature and $A$ is the area of the feature. To determine $d_{u}$, I measured the distance between the digitized outline at normal digitizing scale (1:2000) and at 1:500; for 10 locations around each of 30 G\&PS, for every year of imagery. This method produced 300 sample points per year from which an average value for 
$d_{u}$ was calculated for that year. This approach indirectly addresses variation in imagery quality.

Interpretation uncertainty is caused by skewed imagery, shadow, rock debris, or snow cover. The true boundary of the feature is somewhere between the minimum and maximum boundaries that cover the obscured area, which defines the range of interpretation uncertainty. Digitizing each feature multiple times is inefficient; to accelerate this process, every feature in every year was visually classified into one of three uncertainty categories, as either "high", "medium", or "low" (Table A1). To quantify these uncertainties, the maximum and minimum outlines were digitized for a total sample of 60 G\&PS (20 within each category) from each year of imagery. One half of the difference was taken to be the uncertainty. Assessment of G\&PS boundaries occasionally relied on imagery from adjacent inventories. This was of particular help with perennial snow patches where defining the boundary between new and old snow was vague. Also, because vertical imagery flattens terrain, Google Earth was occasionally used in oblique view to provide a more three-dimensional perspective of the terrain G\&PS perimeter. G\&PS area from previously published reports include no uncertainty.

Positional uncertainty results from image orthorectification. Since the projection is consistent for each image, the area of each polygon is preserved and its exact position in space is unimportant; therefore, the positional uncertainty is considered to be zero. 
Glacier volume change is important for understanding contributions to stream runoff and is estimated in two ways. First, the volume for all G\&PS is estimated using the area-volume scaling relation (2). Second, for the nine glaciers the topography was remapped to define the details of topographic change. Aerial lidar was flown by University of Northern British Columbia, and I created a DEM for each glacier from the lidar point cloud. A cubic convolution interpolation was used to produce a cell size of $\sim 10 \mathrm{~m}$. This large cell size was needed to match the DEM of the $1 / 3$ arc second National Elevation Data produced by the US Geological Survey (https://nationalmap.gov/elevation). Volume change was estimated by differencing the USGS and 2015 DEMs, using the ArcMap 10.4 Raster Calculator (ESRI, 2017). Volume change is calculated by summing the elevation differences for all cells inside the 1966 glacier outlines, multiplied by the cell area. To estimate uncertainty, control zones were selected outside of the glacier on bedrock, free of snow and ice, where no change in elevation should occur. These control zones were identified using 2015 World View imagery (Digital Globe, Inc). Uncertainty estimates were partitioned according to slope because small horizontal offsets in steeper terrain yield larger vertical error (Oschlager 2015). Slope bins were divided into 10-degree intervals from $0^{\circ}$ to $90^{\circ}$. The total volume change in each slope bin is described by,

$$
\begin{gathered}
\Delta V_{j}=A \sum_{i=1}^{n} \Delta Z_{i j}, \\
\Delta V=\sum_{j=1}^{m} \Delta V_{j}
\end{gathered}
$$


where $\Delta \mathrm{V}$ is the total volume change $\left(\mathrm{m}^{3}\right)$ within each slope bin $\mathrm{j}, n$ is the number of cells within each slope, $A$ is the area of a cell $\left(\mathrm{m}^{2}\right), m$ is the number of slope bins, and $\Delta Z$ is the difference in elevation of each cell $i(m)$, within the slope bins. The uncertainty of each slope bin of the bedrock was applied to the same slope bin of the glacier, yielding a slope-weighted uncertainty.

The uncertainty of the elevation differences, $U$, is calculated as the ratio of the root mean square error (RMSE) of the control zones to the RMSE of the glacier elevation differences, yielding a fractional uncertainty, F. The total uncertainty for each bin was calculated using,

$$
U= \pm \frac{F *|\Delta V|}{2}
$$

Climate and Topographic Data

To compare total G\&PS area change with variations in topography and climate, I used the fractional area change of the G\&PS to normalize the magnitude of change between G\&PS. Gridded climate variables of mean, minimum, and maximum monthly temperature and precipitation were acquired from the Parameter Elevation Regression on Independent Slopes Model (PRISM); (Daly et al., 1994) at a scale of $800 \mathrm{~m}$. Using the monthly averages, data were partitioned into seasons based on mean minimum and maximum temperatures. Winter months include December, January and February, and are defined by mean winter minimum and maximum temperatures are $\leq 0^{\circ} \mathrm{C}$; summer months are May, June, July, August, and September, when both mean 
minimum and maximum temperatures are $>0^{\circ} \mathrm{C}$; spring (March and April) and fall (October and November) are months when mean minimum temperature is $\leq 0^{\circ} \mathrm{C}$ and mean maximum temperatures are $>0^{\circ} \mathrm{C}$ above zero (Figure $\mathrm{A} 1$ ).

Topographic variables for each G\&PS were derived from the NED DEM at a spatial resolution of $10 \mathrm{~m}$, and included mean elevation, latitude, longitude, aspect, and mean slope. Also, the G\&PS are grouped according to which side of the Continental Divide they are found because the climate is different.

A Pearson product-moment and a non-parametric Spearman rank correlation were calculated to determine the correlation between the topographic and climate variables and the fractional area changes. The null hypothesis for these correlations is that there are no relationships between the dependent fractional area change or volume change variables, and the independent climate and topographic variables. These two correlations were used because of their different properties (Bonett et al., 2000). The Pearson test assumes a normal distribution and equal variances, and is sensitive to outliers because it is based on how close the correlation follows a linear distribution. It is useful for determining the strength of linear relationships between variables, and relies on data that are normally distributed. The Spearman test has relatively few assumptions and is not as sensitive to outliers because the test statistic is based on ranked values. However, because it ignores the magnitude of outliers, the results can be misleading. Using both methods is stronger when both agree, and 
is also a way of finding data error. All significance is reported at the $95 \%$ confidence interval. 


\section{Results \& Analysis}

The 1966 inventory identified 604 G\&PS with a total area of $40.52 \pm 4.8$ $\mathrm{km}^{2}$, and an estimated volume of $0.263 \pm 0.018 \mathrm{~km}^{3}$. The area uncertainty is $9 \%$ (Fountain \& others, 2017). The 1966 imagery was good quality, based on about a dozen single-frame aerial photographs examined, with little seasonal snow cover obscuring the G\&PS. Some mistakes in the G\&PS outlines were found and corrected. The area of individual G\&PS ranged from $0.001 \mathrm{~km}^{2}$ to $1.75 \mathrm{~km}^{2}$ (Blackfoot Glacier), with an average of $0.067 \mathrm{~km}^{2}$ and a median of $0.017 \mathrm{~km}^{2}$ (Figure 3). The elevation of the centroid of each G\&PS range from $1750 \mathrm{~m}$ to $3155 \mathrm{~m}$, and averaging $2255 \mathrm{~m}$. The mean slopes ranged between $2.1^{\circ}-68.1^{\circ}$ with an average of $30.6^{\circ}$ and most features face north to northeast. Of the 604 G\&PS, 167 (27\%) were identified as glaciers by their basal shear stress, and cover a total area of $33.68 \pm 3.03 \mathrm{~km}^{2}$, with individuals averaging $0.20 \mathrm{~km}^{2}$ and a median of $0.10 \mathrm{~km}^{2}$, and an estimated volume of $0.219 \pm 0.017 \mathrm{~km}^{3}$. The remaining 437 perennial snowfields $(73 \%)$ had a total area of $6.89 \pm 0.62 \mathrm{~km}^{2}$, with an average of $0.016 \mathrm{~km}^{2}$ a median of $0.011 \mathrm{~km}^{2}$, and an estimated volume of $0.045 \pm 0.004 \mathrm{~km}^{3}$. Because of limited available imagery, no visual identification of glaciers were made. 

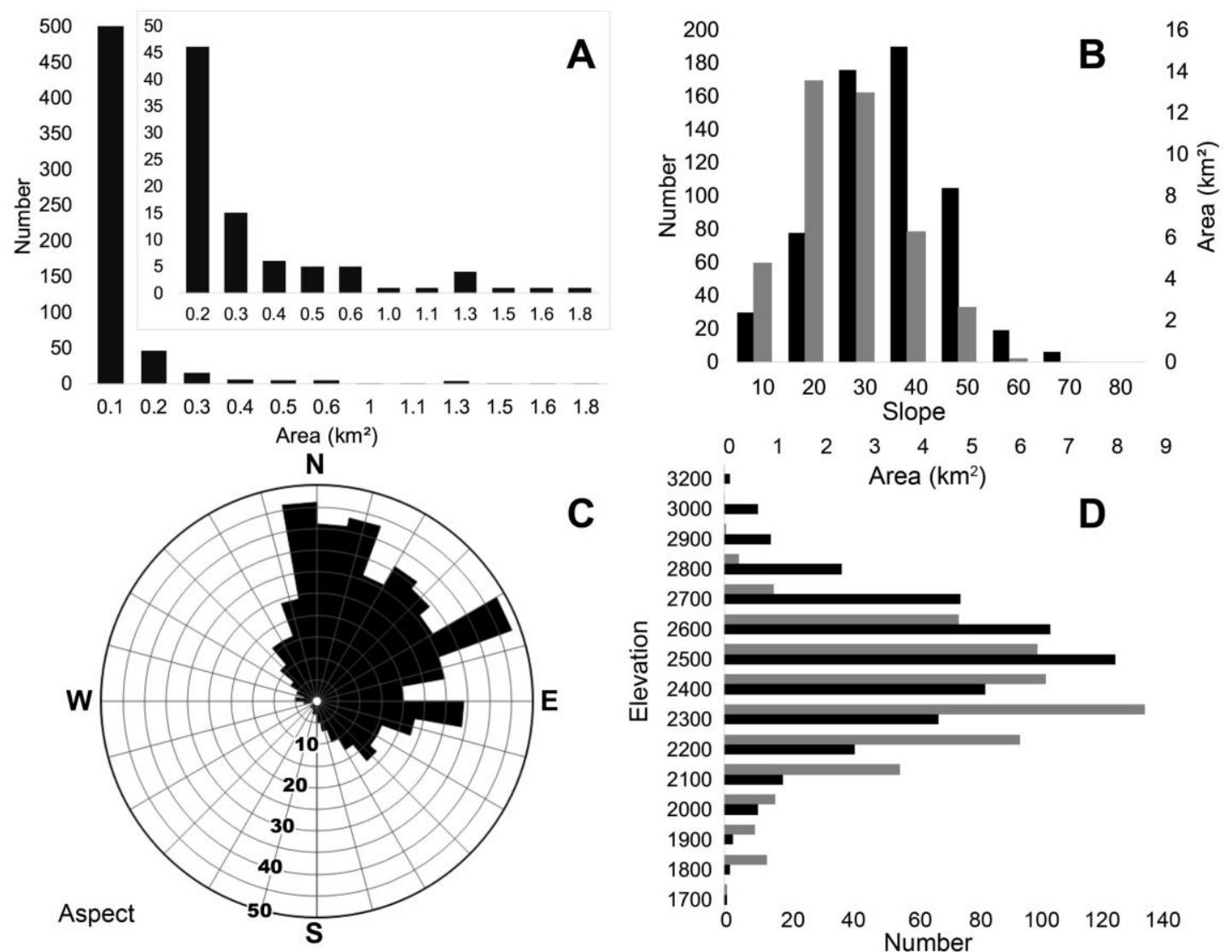

Figure 3. Topographic characteristics of the glaciers and perennial snowfields (G\&PS) from 1966. The black bars correspond to the number of G\&PS, and the gray bars represent the area in $\mathrm{km}^{2}$. A. The number of G\&PS per area, where the inset represents all data smaller than $0.2 \mathrm{~km}^{2}$. B. The number and area of G\&PS as a function of slope. C. Aspect, where the radius represents the number of G\&PS facing that direction, in increments of 5 . D. The number and area of G\&PS as a function of elevation. Bins are defined by their maximum elevation, area, or slope. For example, the slope bin 30 includes all slopes $>20$ and $\leq 30$.

Inventories of G\&PS were compiled for nine different years from 1966 to 2015, and include 1966, 1979, 1991, 1995, 1998, 2003, 2005, 2013 and 2015 Table 2; Table A4). Only the 1966 and 2005 inventories were complete. The others were incomplete due to lack of photographic coverage or seasonal snow 
obscuring the G\&PS outlines. The 1979 inventory is the least complete, but contains 39 large glaciers, the largest in the Park.

Table 2. Number of all features in each inventory. G\&PS is glaciers and perennial snowfields; Not perennial is the number of features that are no longer perennial in each inventory; No imagery is the number of G\&PS for which no imagery was available.

\begin{tabular}{rrrrrrrrrr}
\hline & 1966 & 1979 & 1991 & 1995 & 1998 & 2003 & 2005 & 2013 & 2015 \\
\hline G\&PS & 604 & 39 & 293 & 229 & 150 & 231 & 455 & 264 & 259 \\
Area $\left(\mathrm{km}^{2}\right)$ & 40.52 & 19.92 & 22.87 & 19.25 & 19.37 & 18.49 & 27.28 & 17.10 & 26.46 \\
Not Perennial & 0 & 0 & 69 & 56 & 44 & 130 & 149 & 112 & 121 \\
No Imagery & 0 & 565 & 242 & 319 & 410 & 243 & 0 & 228 & 224
\end{tabular}

The 2005 inventory consists of 455 G\&PS, with a total area of $27.29 \pm$ $2.46 \mathrm{~km}^{2}$, an average of $0.06 \mathrm{~km}^{2}$, a median of $0.01 \mathrm{~km}^{2}$, and a total volume of $0.155 \pm 0.012 \mathrm{~km}^{3}$. Over the $\sim 40$-year period since 1966 the total ice-covered area decreased by $12.26 \pm 1.59 \mathrm{~km}^{2}(-31 \% \pm 13 \%), 149(25 \%)$ G\&PS totaling $1.70 \pm 0.15 \mathrm{~km}^{2}$, are no longer perennial, and the total volume decreased by $0.108 \pm 0.008 \mathrm{~km}^{3}$. It should be noted that the difference in the number of G\&PS between the 1966 and 2005 inventories is due to the assumption that all glacial features on the original topographic maps were G\&PS, although identification is based on one-time imagery. The smallest perennial snowfields $\left(<0.1 \mathrm{~km}^{2}\right)$ showed the most variability in change over this time (Figure 4). Of the 455 G\&PS remaining in 2005, 291 are perennial snowfields, with a total area of $3.22 \pm 0.29$ $\mathrm{km}^{2}$, and 164 are glaciers, with a total area of $24.07 \pm 2.17 \mathrm{~km}^{2}$. Total glacier area has decreased by $-28 \%$ and the perennial snowfield area has decreased by $-46 \%$. 
1966 Area $\left(\mathrm{km}^{2}\right)$

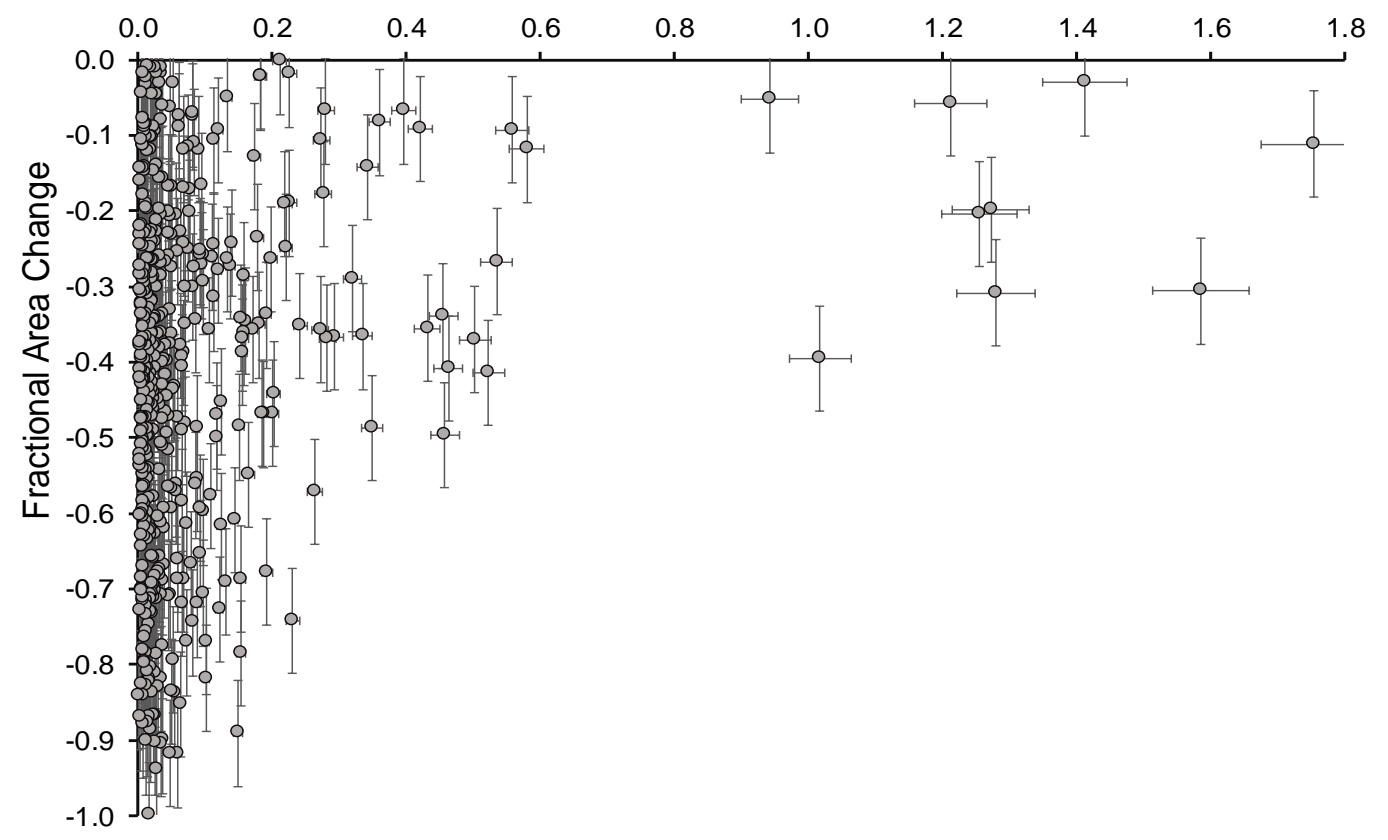

Figure 4. Fractional area change for all G\&PS between 1966 and 2005. Fractional area change is the area change divided by the original area.

To estimate the changes in total glacier area in the Park, the relative area change for G\&PS in complete inventories $(1966,2005)$ was compared to values from partial inventories. For example, the area change between 1966 and 1991 for the 294 G\&PS common to both inventories, was $-13 \%\left(-3.36 \pm 0.6 \mathrm{~km}^{2}\right)$. We assume that this relative loss applies to all G\&PS in 1966, resulting in an estimated loss of $-5.27 \mathrm{~km}^{2}$ from $40.52 \pm 3.65 \mathrm{~km}^{2}$, such that the estimated total G\&PS area in 1991 is $35.25 \mathrm{~km}^{2}$. The same calculation is made, but using the 2005 inventory as a reference, resulting in a $+21 \%$ difference, yielding a 1991 area of $33.01 \mathrm{~km}^{2}$. The average of the two estimates defines the total area for 
1991 , and half of their difference is the uncertainty, $34.13 \pm 1.12 \mathrm{~km}^{2}$. This method was repeated across each partial inventory, assuming that all known areas represent the unknown areas (Table 3).

Table 3. Estimated total G\&PS area for each inventory. The complete inventories of 1966 and 2005 are in bold.

\begin{tabular}{cc}
\hline Year & Estimated Area $\left(\mathbf{k m}^{2}\right)$ \\
\hline $\mathbf{1 9 6 6}$ & $\mathbf{4 0 . 5 2} \pm \mathbf{3 . 6 5}$ \\
$\mathbf{1 9 9 1}$ & $34.81 \pm 1.12$ \\
$\mathbf{1 9 9 5}$ & $34.13 \pm 1.26$ \\
$\mathbf{1 9 9 8}$ & $29.52 \pm 1.69$ \\
$\mathbf{2 0 0 3}$ & $28.09 \pm 0.55$ \\
$\mathbf{2 0 0 5}$ & $\mathbf{2 7 . 2 8} \pm \mathbf{2 . 4 6}$ \\
$\mathbf{2 0 1 3}$ & $27.07 \pm 0.89$ \\
$\mathbf{2 0 1 5}$ & $26.46 \pm 1.09$
\end{tabular}

To provide further detail on how the G\&PS were changing over time, a set of 100 G\&PS common to each inventory, except 1979, were examined (Table 4). To test whether they are representative of the total population of G\&PS, the changes were compared to the population between 1966 and 2005. The 100 G\&PS in 1966 represents $17 \%$ of the total population and $25 \%$ of the total area. In 2005 , the 100 G\&PS represents $22 \%$ of the total population and $25 \%$ of the area. The total change between 1966 and 2005 was $-33 \% \pm 11 \%$ (standard deviation), and the change for the 100 G\&PS was $-32 \% \pm 11 \%$. A one-way analysis of variance (ANOVA) of the area distribution between the 100 G\&PS and the area of all G\&PS for 1966 and 2005 showed that they are not statistically different from either population in 1966 or 2005, and the changes reflect that of the populations. The distribution of G\&PS areas also shifted toward smaller areas over time, becoming more skewed toward the smallest areas. (Figure 5). 
Table 4. Area characteristics of 100 G\&PS across all inventories. U\% is the percent uncertainty for total area in each inventory.

\begin{tabular}{rrrrrrrrr}
\hline Year & $\mathbf{1 9 6 6}$ & $\mathbf{1 9 9 1}$ & $\mathbf{1 9 9 5}$ & $\mathbf{1 9 9 8}$ & $\mathbf{2 0 0 3}$ & $\mathbf{2 0 0 5}$ & $\mathbf{2 0 1 3}$ & $\mathbf{2 0 1 5}$ \\
\hline Mean & 0.102 & 0.087 & 0.090 & 0.080 & 0.064 & 0.069 & 0.073 & 0.063 \\
Median & 0.034 & 0.030 & 0.033 & 0.027 & 0.014 & 0.021 & 0.027 & 0.017 \\
Total Area & $\mathbf{1 0 . 2 0 3}$ & $\mathbf{9 . 4 6 3}$ & $\mathbf{9 . 0 3 7}$ & $\mathbf{7 . 9 7 5}$ & $\mathbf{7 . 1 2 1}$ & $\mathbf{6 . 9 4 0}$ & $\mathbf{6 . 5 4 3}$ & $\mathbf{6 . 2 5 3}$ \\
Uncertainty & 0.918 & 1.392 & 0.994 & 0.558 & 0.514 & 0.625 & 1.029 & 0.438 \\
U\% & $9 \%$ & $16 \%$ & $11 \%$ & $\mathbf{7 \%}$ & $\mathbf{8 \%}$ & $9 \%$ & $14 \%$ & $7 \%$
\end{tabular}


1966

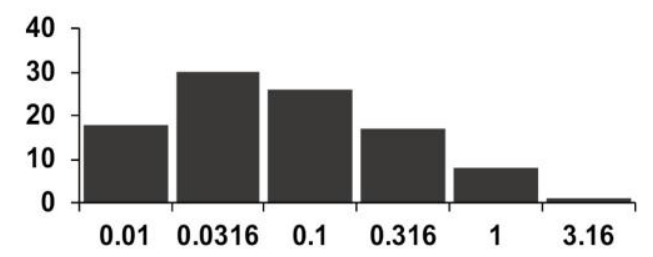

1991
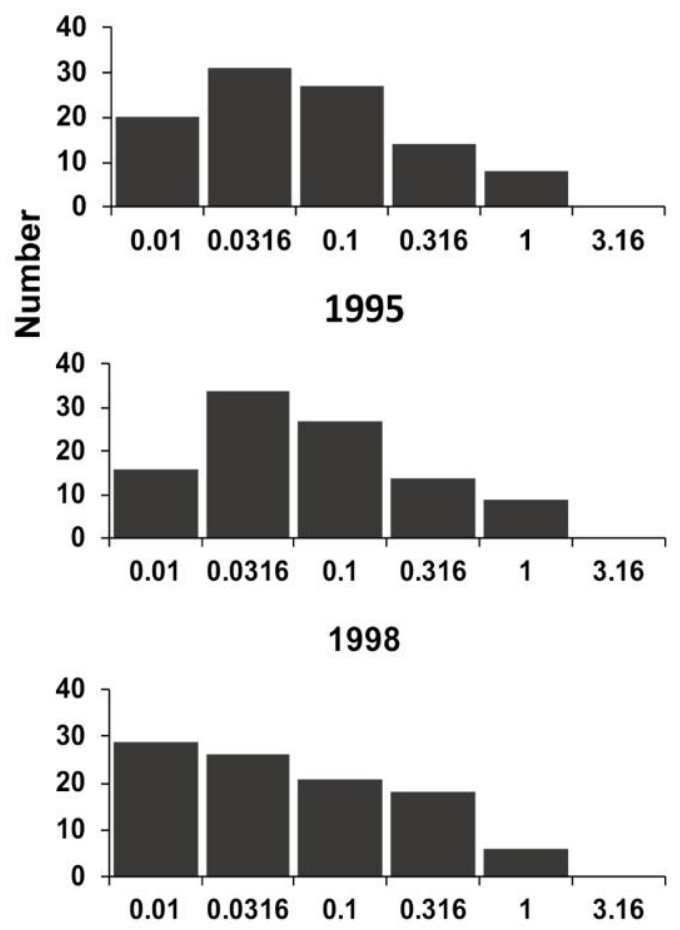

2003

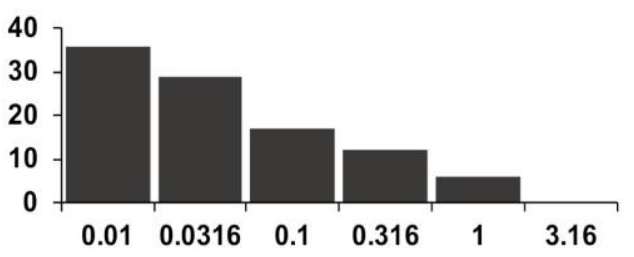

2005

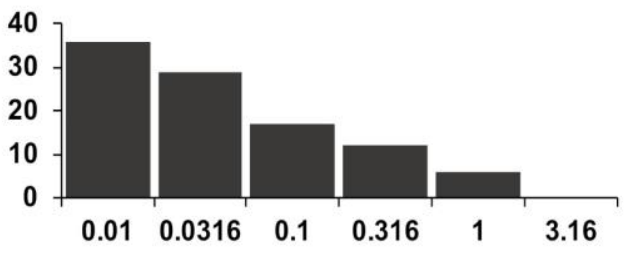

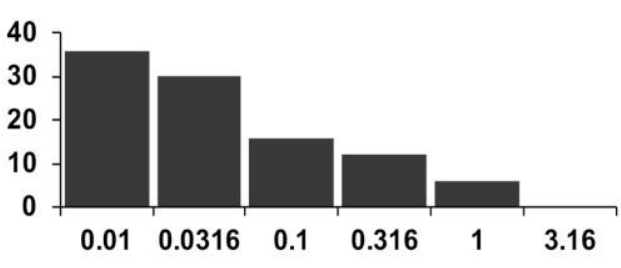

2015

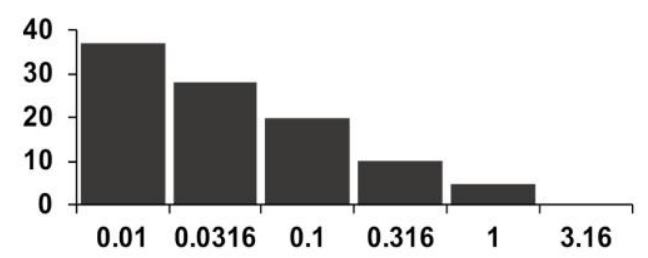

Figure 5. The distribution of glacier and perennial snowfield (G\&PS) areas for the set of 100 G\&PS across all inventories. The vertical axis is the number of G\&PS, and the horizontal axis is the area in log scale. Bins are defined by their maximum area. For example, the slope bin 0.01 includes all areas $>0$ and $\leq 0.01$. 
To examine area change over the longest span of time, a set of six glaciers has data from 1850 to 2015, and includes Agassiz, Grinnell, Harrison, Sperry, Swiftcurrent, and Vulture (Figure 6). Data availability varies, but data exist for all in 1850 and in all inventories from 1966 to 2015 (Table A2). The total area of these six glaciers in 1850 was $\sim 14.48 \mathrm{~km}^{2}$ and in $2015,4.17 \pm 0.29$ $\mathrm{km}^{2}$, a loss of $-10.31 \pm 0.72 \mathrm{~km}^{2}(-71 \% \pm 7 \%$; Figure 7$)$. Area measurements made before the 1960's are based on ground observations and mapped moraines (Key et al., 2002), and no uncertainty is available (Table A3). To test whether they are representative of the total population of G\&PS, the changes in the six glaciers in 1966 and 2005 were compared to the total population between 1966 and 2005, and the largest glaciers in 1966 and $2005\left(\geq 0.1 \mathrm{~km}^{2}\right)$. The area of these six glaciers was in 1966 was $5.88 \pm 0.53 \mathrm{~km}^{2}$, and $4.48 \pm 0.40 \mathrm{~km}^{2}$ in 2005 , an area loss of $-1.40 \pm 0.15 \mathrm{~km}^{2}(-24 \% \pm 11 \%)$. Over this same period the area of all G\&PS changed from $40.52 \pm 3.64 \mathrm{~km}^{2}$ to $27.28 \pm 2.46 \mathrm{~km}^{2}$, a loss of $33 \% \pm 11 \%$. The area of the largest glaciers $\left(\geq 0.1 \mathrm{~km}^{2}\right)$ changed by $-27 \% \pm 11 \%$. The six glaciers are indicative of the larger glaciers in the Park, but underestimate the change of all G\&PS. Based on the ratio of fractional area change of the total G\&PS to the six glaciers over the period 1966 to 2005, the estimated loss of all G\&PS from 1850 to 2015 is $-87 \%$, yielding a 1850 area of $311.69 \mathrm{~km}^{2}$, and a total area change of $-290.32 \pm 20.32 \mathrm{~km}^{2}$ between $\sim 1850$ and 2015. Fitting a linear regression to the data over the entire time period suggests that if the rate of change over the entire time period $\left(-0.06 \mathrm{~km}^{2} \mathrm{yr}^{-1}\right)$ continues 
into the future, all glaciers will disappear by 2080. If the rate of change since 1979 is used $\left(-0.038 \mathrm{~km}^{2} \mathrm{yr}^{-1}\right)$, all glaciers will disappear by 2125 .

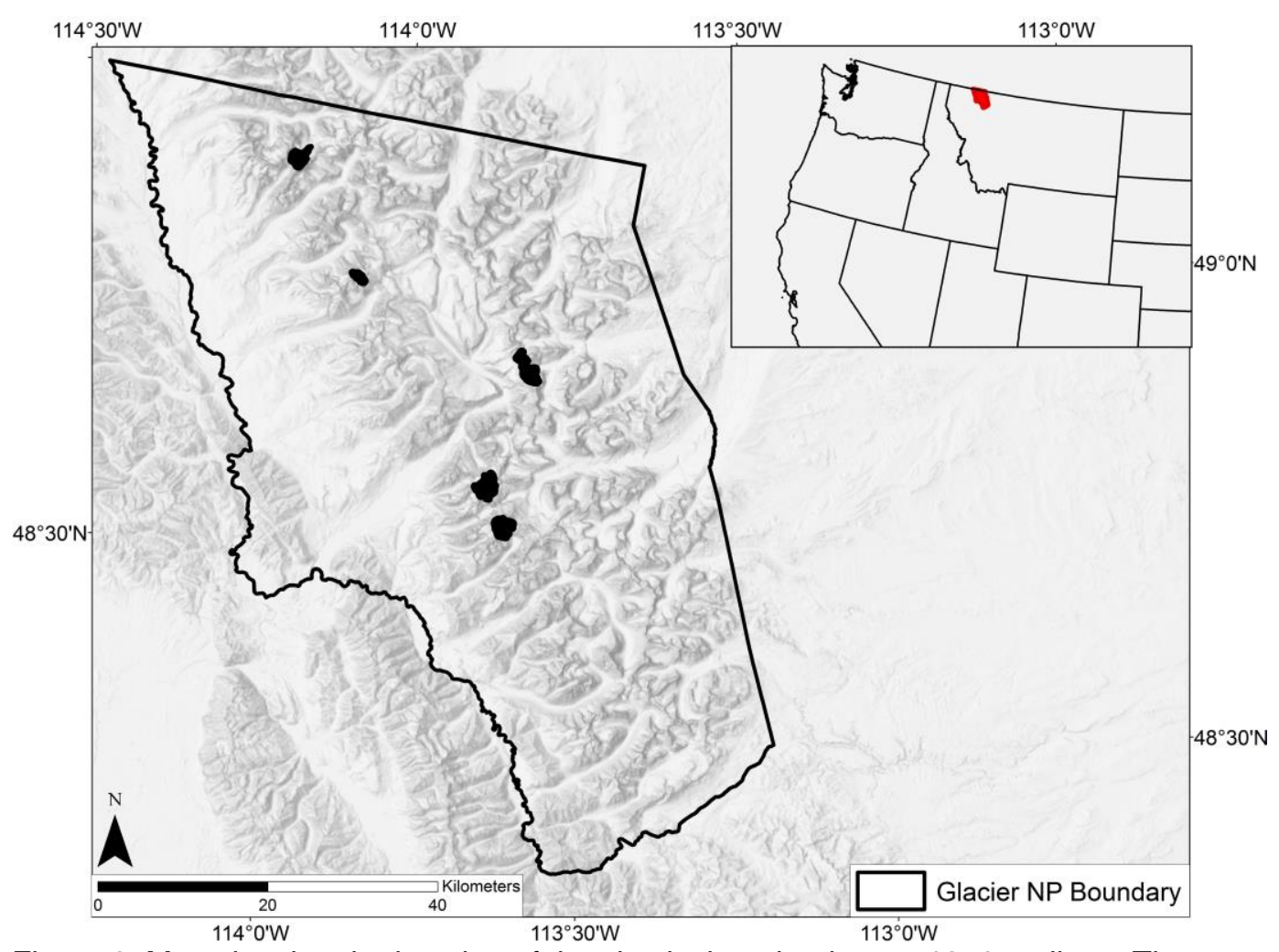

Figure 6. Map showing the location of the six glaciers that have $\sim 1850$ outlines. The black polygons are expanded to show location, and are not to scale. 

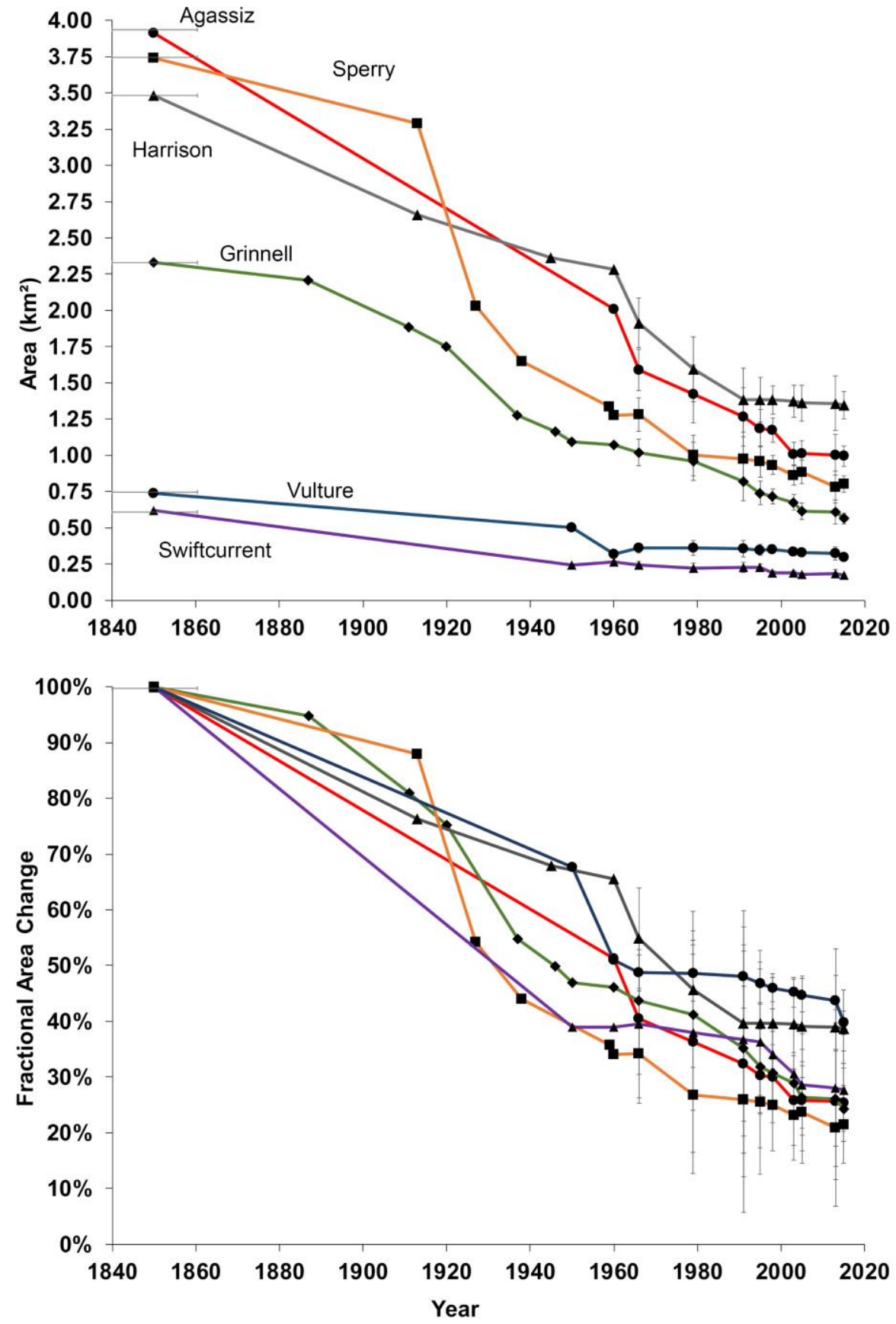

Figure 7. Area change of six glaciers with long-term observations. The oldest area 1850 (LIA), based on mapped moraines, and really represent a period between about 18401960. No uncertainty is available for data between $\sim 1850$ and 1960. Fractional area change is the measured area divided by the original area in $\sim 1850$. 


\section{Volume Change Results}

The volume change between the 1966 and 2005 inventories was estimated by the area-volume scaling relation (2) using the two sets of parameters to define the range. Results show an area change of $12.26 \pm 1.59$ $\mathrm{km}^{2}$ and a volume change of $-0.176 \pm 0.002 \mathrm{~km}^{3}$. The change of individual G\&PS was not examined because of the large uncertainty, which is reduced by compensating errors when summed over a large population (Granshaw \& Fountain, 2006). Detailed volume changes were measured on individual glaciers by comparing updated DEMs to those created using 1966 topographic maps. Of the nine glaciers surveyed by aerial lidar in 2015 , six have complete coverage, and three have small areas missing from the survey, Harrison (90\% coverage), Salamander (90\%) and Jackson (70\%). The area of the glacier that is missing from the lidar survey is excluded from the analysis. All surveyed glaciers lost volume from 1966 to 2015 , with a total loss of $-0.1424 \pm 0.022 \mathrm{~km}^{3}$, and a specific loss of $-16.3 \pm 2.5 \mathrm{~m}$ (Table 5). Grinnell Glacier lost the most, a specific volume loss of $-34.11 \pm 2.46 \mathrm{~m}$ and Swiftcurrent lost the least, $-4.24 \pm 1.66 \mathrm{~m}$. Uncertainty increased nonlinearly with slope, consistent with other studies (Ohlschlager, 2015), ranging from $\pm 4 \mathrm{~m}$ to $\pm 6 \mathrm{~m}$ for slopes $0^{\circ}-30^{\circ}$, and $\pm 30 \mathrm{~m}$ to $\pm 40 \mathrm{~m}$ for slopes $70^{\circ}-90^{\circ}$. Fortunately, the glacier area within each slope bin decreases with increasing slope, such that uncertainty of high slopes make little contribution to overall elevation uncertainty of the glacier. The highest uncertainties are found at Swiftcurrent (39\%) and Agassiz (29\%) glaciers, 
because they have a larger proportion of area at steeper slopes than the other glaciers. Grinnell and Sperry glaciers have the lowest uncertainties, at $7 \%$ and $10 \%$, and the greatest relative area at low slopes. Sperry glacier lost most of its elevation near the terminus and at the lowest slopes (Figure 8). The other glaciers surveyed show similar elevation change, with the greatest loss concentrated near the terminus and at low slopes.

Extrapolating the specific volume loss from surface differences, to all G\&PS in 1966, indicates about $0.660 \pm 0.099 \mathrm{~km}^{3}$ of ice was lost by 2015 . To test the predictive capability of the area-volume scaling, estimates of volume change of individual glaciers was compared to topographic estimates (Table 5). Results show that the two methods have results that differ by $\sim 8 \%$ overall, with the areavolume scaling method typically overestimating volume change for each glacier. Topographic estimates show a specific volume change of $-16.3 \mathrm{~m}$, the areavolume scaling method, $-6.49 \mathrm{~m}$. Overall, the results produce similar results, and are a good comparison for the surveyed glaciers in the Park. 
Table 5. Volume change between 1966 and 2015 for all glaciers surveyed by lidar, compared to those estimated by the area-volume scaling relationship. DEM Vol means digital elevation model volume change, and represents the topographic method for estimating volume change. A/V Vol means area-volume volume change, using and the area-volume scaling method. For total, the volume calculations are summed, and the specific volume changes are averaged.

\begin{tabular}{rrrrr}
\hline Glaciers & $\begin{array}{r}\text { DEM Vol } \\
\text { Change }\left(\mathbf{k m}^{3}\right)\end{array}$ & $\begin{array}{r}\text { DEM Specific Vol } \\
\text { Change }(\mathbf{m})\end{array}$ & $\begin{array}{r}\text { A/V Vol Change } \\
\left(\mathbf{k m}^{3}\right)\end{array}$ & $\begin{array}{r}\text { A/V Specific } \\
\text { Vol Change }(\mathbf{m})\end{array}$ \\
\hline Agassiz & $-0.0144 \pm 0.0040$ & $-9.30 \pm 2.66$ & $-0.0140 \pm 0.0011$ & $-9.05 \pm 0.72$ \\
Blackfoot & $-0.0169 \pm 0.0050$ & $-9.77 \pm 2.66$ & $-0.0057 \pm 0.0004$ & $-3.27 \pm 0.26$ \\
Chaney & $-0.0127 \pm 0.0020$ & $-24.00 \pm 2.93$ & $-0.0038 \pm 0.0003$ & $-7.25 \pm 0.58$ \\
Grinnell & $-0.0339 \pm 0.0020$ & $-34.11 \pm 2.46$ & $-0.0102 \pm 0.0008$ & $-10.22 \pm 0.82$ \\
Harrison & $-0.0185 \pm 0.0040$ & $-14.66 \pm 2.87$ & $0.0021 \pm 0.0002$ & $-3.44 \pm 0.28$ \\
Jackson & $-0.0131 \pm 0.0030$ & $-14.81 \pm 2.91$ & $0.0016 \pm 0.0001$ & $-10.93 \pm 0.87$ \\
Salamander & $-0.0028 \pm 0.0001$ & $-13.95 \pm 2.04$ & $-0.0004 \pm 0.0000$ & $-5.23 \pm 0.42$ \\
Sperry & $-0.0291 \pm 0.0030$ & $-22.92 \pm 2.21$ & $-0.0114 \pm 0.0009$ & $-9.01 \pm 0.72$ \\
Swiftcurrent & $-0.0007 \pm 0.0001$ & $-4.24 \pm 1.66$ & $0.0000 \pm 0.0000$ & $-0.05 \pm 0.00$ \\
TOTAL & $-\mathbf{0 . 1 4 2 0} \pm \mathbf{0 . 0 2 0 0}$ & $-\mathbf{- 1 6 . 3 2} \pm \mathbf{2 . 5 0}$ & $-\mathbf{0 . 0 4 1 9} \pm \mathbf{0 . 0 0 3 4}$ & $-6.49 \pm \mathbf{0 . 5 2}$
\end{tabular}



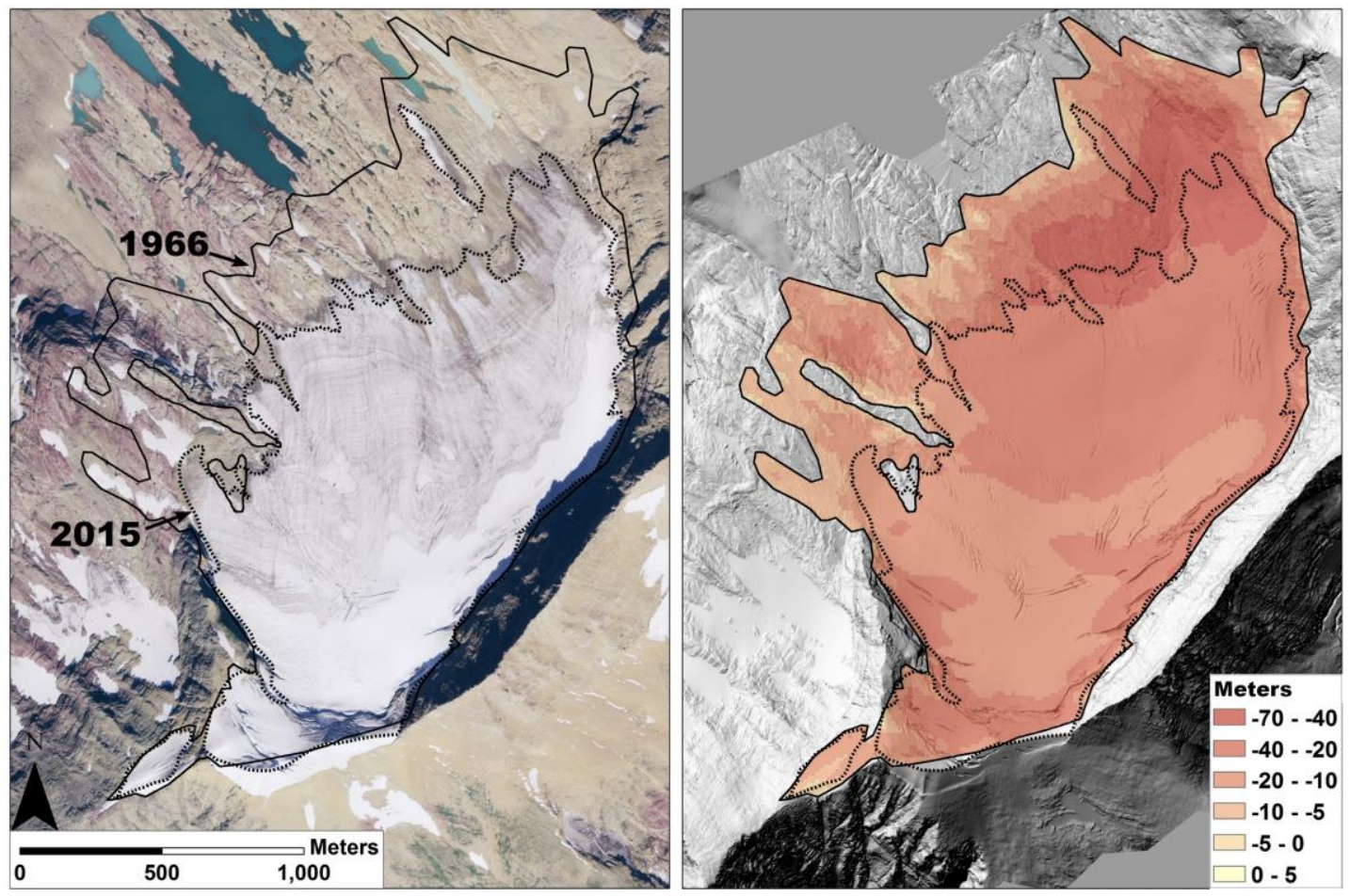

Figure 8. Elevation change of Sperry Glacier. On the left is the 2015 WorldView Satellite image captured on 9/12/15 (Digital Globe). On the right, the base hillshade is created from the 2015 LiDAR. The solid black line is the boundary of the glacier in 1966. The dashed black line is the boundary in 2015.

Climate and Topographic Results

To compare total G\&PS area change with variations in topography and climate, fractional area change between 1966 and 2015 was used as the dependent variable in a statistical correlation analysis, which considered topographic and spatial climate values as independent variables. The number of G\&PS is limited to the 259 that are common to both inventories. Climate variables were extracted for each G\&PS centroid. Given the $800 \mathrm{~m}$ cell size of the PRISM climate model and the proximity of neighboring G\&PS, many have the 
same climate values. They include mean, minimum, and maximum seasonal and annual air temperatures and precipitation. Topographic variables include latitude, longitude, centroid elevation, slope, and aspect. The results show that often, but not always, both the Pearson and Spearman have significant correlations for the same independent variable. Where they do not, we presume, it is the influence of outliers. For all G\&PS, latitude, longitude, and mean elevation are the only variables with significant correlations, caused by the high correlations with the changing G\&PS west of the continental divide.

The negative correlation with latitude suggests more area loss for G\&PS further north, and the positive correlation with longitude suggests more area loss for G\&PS to the west. The snowfields are more sensitive to change with latitude than glaciers, whereas both G\&PS are influenced to some degree by longitude. All G\&PS are significantly and positively correlated with elevation, with less loss at higher elevations. Slope is significantly positively correlated with glacier change across the entire Park. This suggests steeper glaciers retreat less than glaciers on lower slopes.

Seasonal temperatures are only significantly correlated with perennial snowfield change on the west side of the divide. Precipitation shows no significant correlations. Generally, the G\&PS are more sensitive to topographic and climatic variables on the west side relative to the east side, and the G\&PS have lost slightly more on the west side, $-42 \pm 27 \%$ compared to the east side $40 \pm 24 \%$, respectively. Average annual temperatures are slightly warmer on the 
west side than on the east side, $1.53 \pm 7.85 \stackrel{\circ}{\circ}$; $1.25 \pm 7.90 \stackrel{\circ}{ } \mathrm{C}$, respectively. Summer and winter average temperatures are also warmer in the west than in the east as well, $9.39 \pm 6.15^{\circ} \mathrm{C} ; 9.15 \pm 6.10^{\circ} \mathrm{C}$, respectively for summer, and $6.41 \pm 3.53^{\circ} \mathrm{C} ;-6.75 \pm 3.53^{\circ} \mathrm{C}$, respectively for winter. The average G\&PS elevation is about $130 \mathrm{~m}$ higher in the west and slightly less steep $\left(3^{\circ} \pm 2^{\circ}\right)$ than in the east. Although the G\&PS in the west are at higher elevation than the east, all G\&PS in the west are subject to year-round warmer temperature than those in the east. These warmer air temperatures could be causing the G\&PS to lose seasonal snow cover earlier in the season, exposing the ice to warmer air and solar radiation earlier and longer than in the east.

Perennial snowfields are generally more sensitive to topographic and climate variables than the glaciers. Perennial snowfields are typically smaller and shrink more than glaciers, averaging $0.02 \pm 0.02 \mathrm{~km}^{2}$ versus $0.26 \pm 0.29 \mathrm{~km}^{2}$, and $-44 \% \pm 53 \%$, versus $-36 \% \pm 26 \%$. Also, the average elevation of perennial snowfields is higher than the average elevation of the glaciers, $2262 \pm 222 \mathrm{~m}$; $2236 \pm 207 \mathrm{~m}$. The smaller perennial snowfields may be more sensitive to rising minimum average annual temperatures, which have increased by $\sim 2.4{ }^{\circ} \mathrm{C}$ in the last $\sim 50$ years, because they are thinner and may shrink more (Figure 9). 


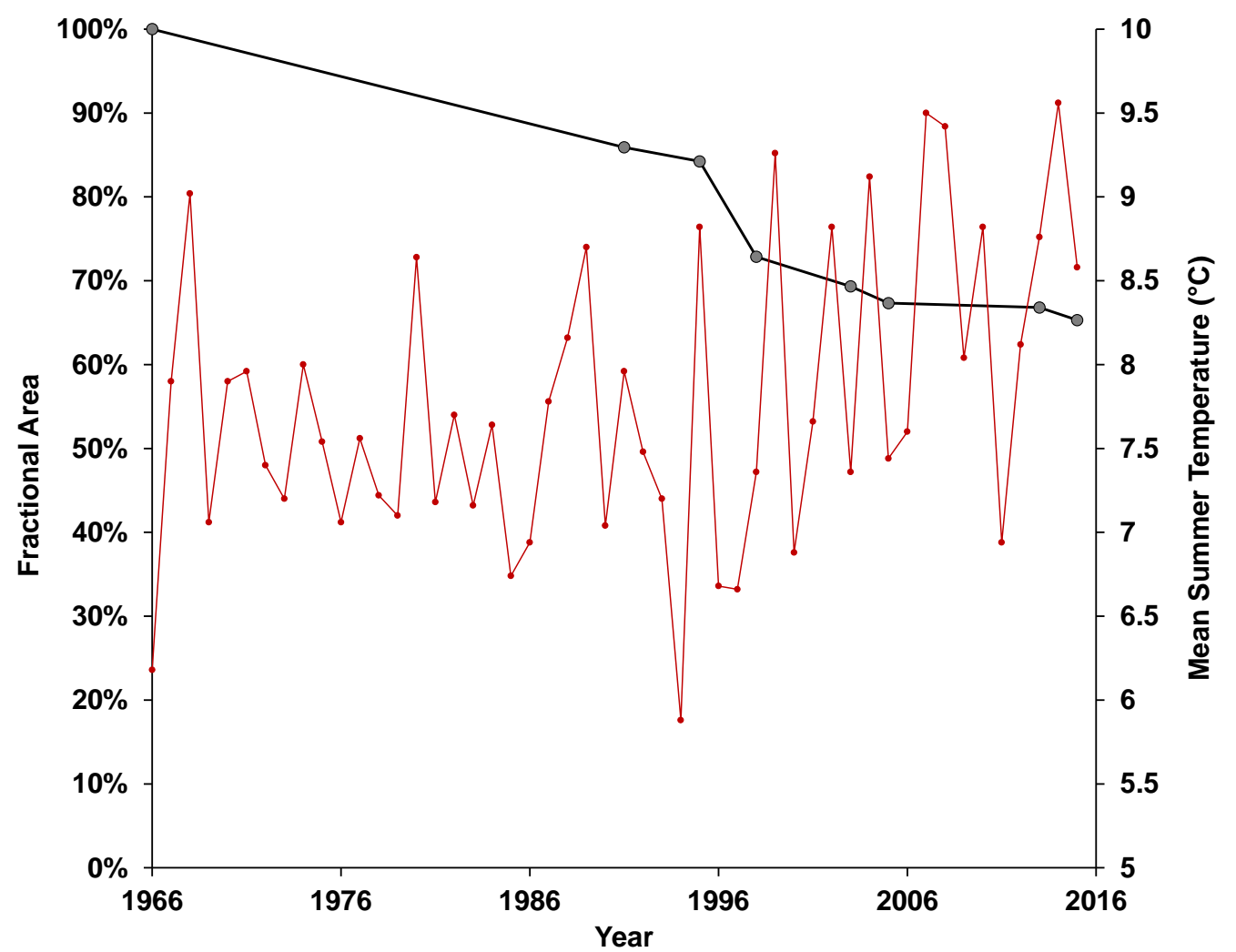

Figure 9. Fractional area change and regional average summer temperature from 1966 to 2015 
Table 6. Pearson and Spearman correlation statistics for fractional area change of glaciers and perennial snowfields (G\&PS) relative to their topographic characteristics in 1966 and climate over the period 1966 to 2015. West and East are the fractional area change of G\&PS on either side of the continental divide. "P" is the Pearson correlation coefficient, and " $\mathrm{S}$ " is the Spearman correlation coefficient. Significant correlations are in bold type.

\begin{tabular}{|c|c|c|c|c|c|c|}
\hline \multirow{3}{*}{$\begin{array}{l}\text { Climate \& } \\
\text { Topographic } \\
\text { Variables }\end{array}$} & \multicolumn{6}{|c|}{$\begin{array}{l}\text { Fractional Area } \\
\text { Change }\end{array}$} \\
\hline & \multicolumn{2}{|l|}{ All G\&PS } & \multicolumn{2}{|l|}{ West } & \multicolumn{2}{|l|}{ East } \\
\hline & $\mathbf{P}$ & $S$ & $\mathbf{P}$ & $\mathbf{S}$ & $\mathbf{P}$ & $\mathrm{s}$ \\
\hline Latitude & -0.180 & -0.171 & -0.184 & -0.184 & -0.181 & -0.177 \\
\hline Longitude & 0.084 & 0.080 & 0.162 & 0.158 & 0.038 & 0.029 \\
\hline Northness & -0.005 & -0.003 & -0.002 & 0.003 & -0.006 & -0.004 \\
\hline Eastness & 0.000 & -0.005 & 0.102 & 0.085 & -0.060 & -0.068 \\
\hline Elevation & 0.157 & 0.148 & 0.149 & 0.123 & 0.163 & 0.180 \\
\hline Slope & -0.078 & -0.084 & -0.054 & -0.058 & 0.367 & 0.305 \\
\hline PPT_Fall & 0.133 & 0.134 & 0.055 & 0.077 & 0.174 & 0.181 \\
\hline PPT_Winter & 0.169 & 0.154 & 0.115 & 0.116 & 0.199 & 0.192 \\
\hline PPT_Spring & 0.159 & 0.154 & 0.147 & 0.154 & 0.168 & 0.168 \\
\hline PPT_Summer & 0.098 & 0.117 & 0.081 & 0.117 & 0.106 & 0.138 \\
\hline PPT_ANNUAL & 0.152 & 0.148 & 0.104 & 0.121 & 0.177 & 0.183 \\
\hline TMIN_Fall & -0.021 & 0.005 & -0.087 & -0.060 & 0.054 & 0.037 \\
\hline TMIN_Winter & 0.060 & 0.062 & -0.066 & -0.043 & 0.136 & 0.058 \\
\hline TMIN_Spring & -0.032 & -0.008 & -0.090 & -0.062 & 0.099 & 0.013 \\
\hline TMIN_Summer & -0.023 & 0.013 & -0.034 & -0.004 & 0.065 & 0.037 \\
\hline TMIN_ANNUAL & -0.005 & 0.019 & -0.071 & -0.043 & 0.031 & 0.088 \\
\hline TMEAN_FALL & -0.075 & -0.046 & -0.089 & -0.066 & -0.068 & -0.026 \\
\hline TMEAN_Winter & 0.049 & 0.052 & -0.078 & -0.042 & 0.119 & 0.140 \\
\hline TMEAN_Spring & -0.053 & -0.028 & -0.092 & -0.063 & -0.032 & 0.007 \\
\hline TMEAN_Summer & -0.088 & -0.067 & -0.057 & -0.038 & -0.111 & -0.083 \\
\hline TMEAN_ANNUAL & -0.046 & -0.020 & -0.080 & -0.049 & -0.029 & 0.011 \\
\hline TMAX_F̄all & -0.119 & -0.089 & -0.087 & -0.069 & -0.141 & -0.103 \\
\hline TMAX_Winter & 0.034 & 0.040 & -0.084 & -0.037 & 0.099 & 0.116 \\
\hline TMAX_Spring & -0.068 & -0.053 & -0.091 & -0.062 & -0.057 & -0.030 \\
\hline TMAX_Summer & -0.121 & -0.116 & -0.067 & -0.071 & -0.157 & -0.147 \\
\hline TMAX_Annual & -0.080 & -0.059 & -0.084 & -0.060 & -0.080 & -0.055 \\
\hline
\end{tabular}




\section{Discussion \& Conclusions}

Like most of the western U.S., (Fountain et al., 2017), the G\&PS of Glacier National Park are small, averaging $0.098 \mathrm{~km}^{2}$ in 1966 . Since that time until 2015, G\&PS have been shrinking and the smaller ones disappearing, consistent with a warming climate. Over the 49-year period from 1966 to 2015, 159 G\&PS disappeared overall, and total area shrank by $-35 \%$, consistent with area changes observed elsewhere in the western U.S., including the Wind River Range in Wyoming, -30\% between 1966 and 2015 (DeVisser \& Fountain, 2015), and the Columbia (-5\%) and Rocky Mountains (-15\%) in Canada, between 1951 and 2001 (DeBeer et al., 2007). For a longer period, from the LIA ( 1850) to 2000 , the change for the six Park glaciers of $-71 \%$ is also consistent, but larger than elsewhere in the western U.S., including the Sierra Nevada, LIA to 2004, 55\% (Basagic \& Fountain, 2011), the Colorado Front Range, LIA to 2001, $-34 \%$ (Hoffman et al., 2007). The long-term changes in the Park are also comparable to, but larger than, global glacier changes observed in the Southern Alps of New Zealand, LIA to 1970 's, $-49 \%$, and the European Alps, LIA to 1970 's, $-35 \%$ (Hoelzle et al. 2007).

An important feature in the methods was comparison of G\&PS outlines over time. Large and abrupt changes, detected by this comparison, were often due to different assumptions and interpretations regarding the glacier boundary. The comparison over time forced a consistency in interpretation as well as insight of the perennial nature of the features. 
Sperry Glacier has been studied extensively and is a benchmark glacier for the U. S. Geological Survey (Clark et al., 2017). The glacier area is measured by the USGS, and small differences between their results and this thesis is due to my inclusion of any small separated pieces of the retreated glacier that were found within the 1966 boundary, rather than just the area of the main body, as monitored by the USGS. Area changes from the USGS studies are comparable to this study. For example, the glacier (main body) in 2005 is $0.86 \pm 0.08 \mathrm{~km}^{2}$ (Fagre, 2017), compared to my 2005 area, $0.89 \pm 0.06 \mathrm{~km}^{2}$, which includes the remaining perennial ice patches. If you exclude the small ice bodies from my area estimate, the resulting area matches that of the USGS. Cumulative mass balance measurements show that the glacier lost $-4.37 \mathrm{~m}$ of water equivalent (average vertical thinning) between 2005 and 2015 (Clark et al., 2017). This negative trend in mass balance is consistent with the negative trend of glacier area, $-0.08 \mathrm{~km}^{2}$, over the decade.

Variations within the Park showed that G\&PS at lower elevations lost more area than those at higher elevations. Also, smaller perennial snowfields, on average, lose more fractional area than the larger G\&PS. However the variability in fractional area change is much greater for the smaller G\&PS than it is for the larger G\&PS, consistent with Granshaw and Fountain (2006) and DeBeer (2007). On the west side of the Park, air temperatures are $+0.2^{\circ} \mathrm{C}$ to $+0.4^{\circ} \mathrm{C}$ warmer than in the east, and G\&PS in the west are experiencing slightly more loss than those on the east side, $-42 \%$ versus $-40 \%$. 
As expected from the area loss, the G\&PS lost volume as well. Extrapolating volume loss over the 1966 to 2015 period from the nine glaciers surveyed with lidar show a loss of about $-0.660 \pm 0.099 \mathrm{~km}^{3}$ of ice. By comparison, volume loss based on area-volume scaling over the same 49-year period shows a total loss of $-0.263 \pm 0.02 \mathrm{~km}^{3}$. Most of the volume lost occurred at lower elevations of the glaciers as the glaciers thinned, consistent with how glaciers thin and retreat (Cuffey and Patterson, 2010). The lidar survey suggests a specific volume loss at GNP averaged $-16.2 \pm 2.5 \mathrm{~m},(-6.49 \pm 0.52 \mathrm{~m}$ for areavolume scaling), and similar to that at Mount Rainier -15 m from 1970 to 2008 (Sisson, 2010), and at Three Sisters, -11.3 m from 1957 to 2010, (Ohlschlager, 2015).

The G\&PS in the Park face mostly north to northeast, and as they retreat to higher elevations they are becoming less exposed to warm air temperatures and are shaded from solar radiation. Smaller glaciers will tend to receive more of their snow accumulation from avalanching off steep terrain, such as found in GNP, and are therefore less sensitive to variations in direct snowfall (Kuhn, 1995). However, declining winter snowpack and rising summer temperatures will likely eventually cause the glaciers in the Park to disappear completely. If glaciers continue the same trend from $\sim 1850$ to 2015 , and 1979 to 2015 , they will disappear in about 2080 or 2125. 


\section{References}

Alden, W. C., Glaciers of Glacier National Park, 1914, U.S. Department of the Interior, p. 3.

Alt, D., and Hyndman, W., 1986: Roadside Geology of Montana. Missoula, MT, Mountain Press, 427 pp.

Bahr, D.B., Meier, M.F., and Peckham, S.D., 1997, The physical basis of glacier volume-area scaling, Journal of Geophysical Research, v. 102, n. 89, p. 20,355-20,362.

Basagic, H. J., and Fountain, A. G., 2011, Quantifying $20^{\text {th }}$ century glacier change in the Sierra Nevada, California, Arctic, Antarctic, and Alpine Research, v. 43, p. 317-330.

Bekker, M.F., 2005, Positive feedback between tree establishment and patterns of subalpine forest advancement, Glacier National Park, Montana, Arctic, Antarctic and Alpine Research, v. 37, p. 97-100.

Bellaire, S., Jamieson, B., 2013, Forecasting the formation of critical snow layers using a coupled snow cover and weather model, Cold regions science and technology, v. 94 , p. $37-44$.

Bonett, D. G., Wright, T. A., 2000, Sample size requirements for estimating Pearson, Kendall, and Spearman correlations. Psychometrics, v. 65., p. $23-28$.

Carrara, P. E., and McGimsey, R. G., 1981, The late neoglacial histories of the Agassiz and Jackson glaciers, Glacier National Park, Montana, Arctic and Alpine Research, v. 13, p. 183-196.

Chen, J., and Ohmura, A., 1990, Estimation of alpine glacier water resources and their change since the 1870s., International Association of Hydrological Sciences Publication, v. 193, p. 127-135.

Clark, A. M., Fagre, D. B., 2017, Glaciological measurements and mass balance from Sperry G;acier, Montana, U. S. A., years 2005 to 2015. Earth Science Data, v. 9, p. $47-61$.

Daly, C., Taylor, G., and Gibson, W., 1997: The PRISM approach to mapping precipitation and temperature. Proceedings of the 10th Conference on Applied Climatology, Reno, NV, American Meteorological Society, 10-12. 
Cuffey, K.M., and Paterson, W.S.B., 2010, The physics of glaciers, ButterworthHeinemann/Elsevier, Burlington, MA, 693p.

DeBeer, C.M., and Sharp, M.J., 2007, Recent changes in glacier area and volume within the southern Canadian Cordillera, Annals of Glaciology, v. 46 , p. $215-221$.

DeVisser, M.H., and Fountain, A. G., 2015, A century of glacier change in the Wind river Range, WY, Geomorphology, v. 232, p. 103-116.

Dightman, R. A., Beatty, M. E., 1952, Recent Montana glacier and climate trends, Monthly Weather Review, v. 80, p. 76-82.

Driedger, C. L., Kennard, P. M., Ice volumes on Cascade Volcanoes: Mount Rainier, Mount Hood, Three Sisters, and Mount Shasta. Professional paper 1365. USGS, 1984.

Dyson, J. L., Recent glacier recession in Glacier National Park, Montana. Journal of Geology, v. 49, p. $815-824$.

Finklin, A. I. 1986. A climatic handbook for Glacier National Park, with data for Waterton Lakes National Park. USDA Forest Service General Technical Report GTR-INT-204, 124 pp.

Fischer, M., Huss, M., Barboux, C., and Hoelzle, M., 2014: The new Swiss Glacier Inventory SGI2010: relevance of using high-resolution source data in areas dominated by very small glaciers. Arctic, Antarctic, and Alpine Research, v. 46 , p. 933-945.

Fountain, A.G., and Tangborn, W.V., 1985, The effect of glaciers on streamflow variations, Water Resources Research, v. 21, n. 4, p. 579-586.

Fountain, A. G., and Walder, J. S., 1998, Water flow through temperate glaciers, Review of Geophysics, v. 36, p. 301-303.

Fountain, A.G., Hoffman, M., Jackson, K., Basagic, H., Nylen, T., and Percy, D., 2007, Digital outlines and topography of the glaciers of the American West, U.S. Geological Survey Open-File Report 2006-1340.

Fountain, A. G., Glenn, B., Basagic, H. J., 2017, The geography of glaciers and perennial snowfields in the American West. Institute of Arctic and Alpine Research, v. 49, p. $391-410$. 
Ghilani, C.D., 2000, Demystifying Area Uncertainty: More or Less, Surveying and Land Information Systems, v. 60 p. 177-182.

Granshaw, F.D., and Fountain, A.G., 2006, Glacier change (1958-1998) in the North Cascades National Park Complex, Washington, USA, Journal of Glaciology, v. 52, n. 177, p. 251-256.

Hall, M. H. P. and Fagre, D. B., 2003, Model Climate-Induced Glacier Change in Glacier National Park, 1850 - 2100. BioScience, v. 53, p. $131-135$.

Hoelzle, M., Chinn, T., 2007, The application of glacier inventory data for estimating past climate change effects on mountain glaciers: A comparison between the European Alps and the Southern Alps of New Zealand. Global and Planetary Change, v. 56, p. $69-82$.

Hoffman, M.J., Fountain, A.G., Achuff, J.M., 2007. $20^{\text {th }}$ century variations in area of cirque glaciers and glacierets, Rocky Mountain National Park, Rocky Mountains, Colorado, USA. Ann. Glaciology, v. 46, 349-354.

IPCC, 2014: Climate Change 2014, Synthesis report. Contribution of working groups I, II, and III to the Fifth Assessment Report of the Intergovernmental Panel on Climate Change [Core writing team, R. K. Pachauri and L. A. Meyer], IPCC, Geneva, Switzerland, 151 pp.

Key, C. H., Fagre, D. B., and Menicke, R. K. 2002, Glacier Retreat in Glacier National Park, Montana. p. 317-320., U. S. Geological Survey Professional Paper, United States Government Printing Office, Washington D. C., USA.

Klasner, F. L., Fagre, D. B., A half century of change in alpine treeline patterns at Glacier National Park, Montana, U. S. A., Arctic, Antarctic, and Alpine Research, v. 34, p. $49-56$.

Kuhn, I. M. 1995. The mass balance of very small Glaciers. Zeitschrift für Gletscherkunde und Glazialgeologie, Band, 31(S):171-179.

Luckman, B. H., 2000, The little ice age in the Canadian Rockies, Geomorphology, v. 32, p. 357-384.

Meier, M. F., Dyurgerov, M. B., Rick, U. K., O'Neel, S., Pfeffer, W. T., Anderson, R. S., Anderson, S. P. and Glazovsky, A. F. 2007. Glaciers Dominate Eustatic Sea-Level Rise in the 21st Century. Science, 317(5841):10641067. 
Mool, P. K., Wangda, D., Bajracharya, S. R., Kunzang, K., Gurung, D. R., and Joshi, S. P., 2001: Inventory of Glaciers, Glacial Lakes and Glacial Lake Outburst Floods, Monitoring and Early Warning Systems in the Hindu Kush-Himalaya Region: Bhutan. Kathmandu, Nepal: ICIMOD

Moore, R. D., Fleming, S. W., Menounos, B., 2009, Glacier change in western North America: influences on hydrology, geomorphic hazards and water quality, Hydrological Processes, v. 23, pp. 46-50.

NAIP, National Agriculture Imagery Program, United States Department of Agriculture, Information Sheet, August 2013.

Oerlemans, J., 2005, Extracting a Climate Signal from 169 Glacier Records, Science 308, p. 675-677.

Ohlschlager, J. G., 2015, Glacier change on the Three Sister Volcanoes, Oregon: 1900-2010 [M. S. thesis]: Portland State University, 138p.

Pederson, G. T., Gray, S. T., Fagre, D. B., Graumlich, L. J., 2006, Long duration drought variability and impacts on ecosystem services: A case study from Glacier National Park, Montana, Earth Interactions, v. 10, p. 4-7.

Roe, G. H., Baker, M. B., Herla, F., 2017, Centennial glacier retreat as categorical evidence of regional climate change. Nature Geosciences, v. 63 , p. $95-99$.

Tangborn, W. V., Fountain, A. G. and Sikonia, W. G. 1990. Effect of Area Distribution with Altitude on Glacier Mass Balance - A comparison of North and South Klawatti Glaciers, Washington State, U.S.A. Annals of Glaciology, 14:278-282.

Williams Jr., R.S., and Ferrigno, J.G., 2005: Satellite image atlas of glaciers of the world. U.S. Geological Survey Fact Sheet 2005-3056.

Yue, S., Pilon, P., Cavadias, G., 2002, Power and Speaman's rho tests for detecting monotonic trends in hydrological series. Journal of Hydrology, v. 259 , p. $254-271$. 


\section{Detailed Annual Data (Appendix A)}

Table A1. Uncertainty of the digitized glaciers and perennial snowfields (G\&PS) categorized by "high", "medium", and "low" uncertainties for each inventory, along with total uncertainty for each year. " $U$ " is the uncertainty in $\mathrm{km}^{2}$, " $U \%$ " is percent uncertainty, and number is the number of G\&PS.

\begin{tabular}{|c|c|c|c|c|}
\hline & Area $\left(\mathrm{km}^{2}\right)$ & $\mathrm{U}\left(\mathrm{km}^{2}\right)$ & U \% & Number \\
\hline \multicolumn{5}{|l|}{1979} \\
\hline High & 2.208 & 0.722 & $33 \%$ & 10 \\
\hline Medium & 11.228 & 2.316 & $21 \%$ & 21 \\
\hline Low & 6.480 & 0.813 & $13 \%$ & 7 \\
\hline Total & 19.917 & 3.851 & $19 \%$ & 39 \\
\hline \multicolumn{5}{|l|}{1991} \\
\hline High & 0.189 & 0.077 & $41 \%$ & 16 \\
\hline Medium & 11.767 & 2.572 & $22 \%$ & 234 \\
\hline Low & 10.930 & 0.984 & $9 \%$ & 44 \\
\hline Total & 22.886 & 3.633 & $16 \%$ & 294 \\
\hline \multicolumn{5}{|l|}{1995} \\
\hline High & 0.312 & 0.091 & $29 \%$ & 12 \\
\hline Medium & 11.759 & 1.176 & $10 \%$ & 200 \\
\hline Low & 7.235 & 0.289 & $4 \%$ & 20 \\
\hline Total & 19.306 & 1.556 & $11 \%$ & 232 \\
\hline \multicolumn{5}{|l|}{1998} \\
\hline High & 0.054 & 0.013 & $24 \%$ & 11 \\
\hline Medium & 2.540 & 0.254 & $9 \%$ & 87 \\
\hline Low & 16.763 & 0.838 & $5 \%$ & 54 \\
\hline Total & 19.356 & 1.105 & $7 \%$ & 152 \\
\hline \multicolumn{5}{|l|}{2003} \\
\hline High & 0.333 & 0.097 & $33 \%$ & 22 \\
\hline Medium & 4.931 & 0.641 & $12 \%$ & 169 \\
\hline Low & 13.222 & 0.793 & $6 \%$ & 39 \\
\hline Total & 18.487 & 1.531 & $8 \%$ & 230 \\
\hline \multicolumn{5}{|l|}{2005} \\
\hline High & 0.650 & 0.202 & $31 \%$ & 37 \\
\hline Medium & 8.089 & 0.971 & $12 \%$ & 178 \\
\hline Low & 18.541 & 1.297 & $7 \%$ & 389 \\
\hline Total & 27.281 & 2.455 & $9 \%$ & 604 \\
\hline \multicolumn{5}{|l|}{2013} \\
\hline High & 0.465 & 0.140 & $30 \%$ & 36 \\
\hline Medium & 8.273 & 0.745 & $9 \%$ & 183 \\
\hline Low & 10.465 & 0.419 & $4 \%$ & 28 \\
\hline Total & 19.202 & 1.303 & $14 \%$ & 247 \\
\hline \multicolumn{5}{|l|}{2015} \\
\hline High & 0.265 & 0.085 & $32 \%$ & 13 \\
\hline Medium & 9.475 & 0.794 & $16 \%$ & 135 \\
\hline Low & 10.991 & 0.659 & $5 \%$ & 108 \\
\hline Total & 20.730 & 1.538 & $7 \%$ & 256 \\
\hline
\end{tabular}


Appendix Table A2. Area $\left(\mathrm{km}^{2}\right)$ data for the set of historical glaciers spanning between $\sim 1850$ and 2015. The number of significant digits are identical to those reported.

\begin{tabular}{rrrrrrr}
\hline Year & Agassiz & Grinnell & Harrison & Sperry & Swiftcurrent & Vulture \\
\hline 1850 & 3.91 & 2.33 & 3.48 & 3.74 & 0.62 & 0.74 \\
1879 & & & & & & \\
1887 & & 2.21 & & & & \\
1900 & & & & & & \\
1901 & & & & & & \\
1911 & & 1.89 & & & & \\
1913 & & & 2.66 & 3.29 & & \\
1920 & & 1.75 & & & & \\
1926 & & & & & & \\
1927 & & & & 2.03 & & \\
1937 & & 1.28 & & & & \\
1938 & & & & 1.65 & & \\
1945 & & & 2.37 & & & \\
1946 & & 1.16 & & & & \\
1950 & & 1.09 & & & & \\
1959 & & & & 1.33 & & \\
1960 & 2.01 & 1.07 & 2.28 & 1.28 & 0.24 & \\
1966 & 1.586 & 1.018 & 1.913 & 1.281 & 0.245 & 0.361 \\
1979 & 1.422 & 0.959 & 1.592 & 1.000 & 0.224 & 0.360 \\
1991 & 1.266 & 0.818 & 1.381 & 0.972 & 0.228 & 0.356 \\
1995 & 1.186 & 0.740 & 1.383 & 0.956 & 0.226 & 0.347 \\
1998 & 1.174 & 0.716 & 1.382 & 0.934 & 0.189 & 0.352 \\
2003 & 1.008 & 0.674 & 1.375 & 0.864 & 0.190 & 0.335 \\
2005 & 1.011 & 0.616 & 1.360 & 0.886 & 0.178 & 0.331 \\
2013 & 1.003 & 0.608 & 1.359 & 0.782 & 0.185 & 0.324 \\
2015 & 0.995 & 0.564 & 1.346 & 0.804 & 0.172 & 0.294
\end{tabular}




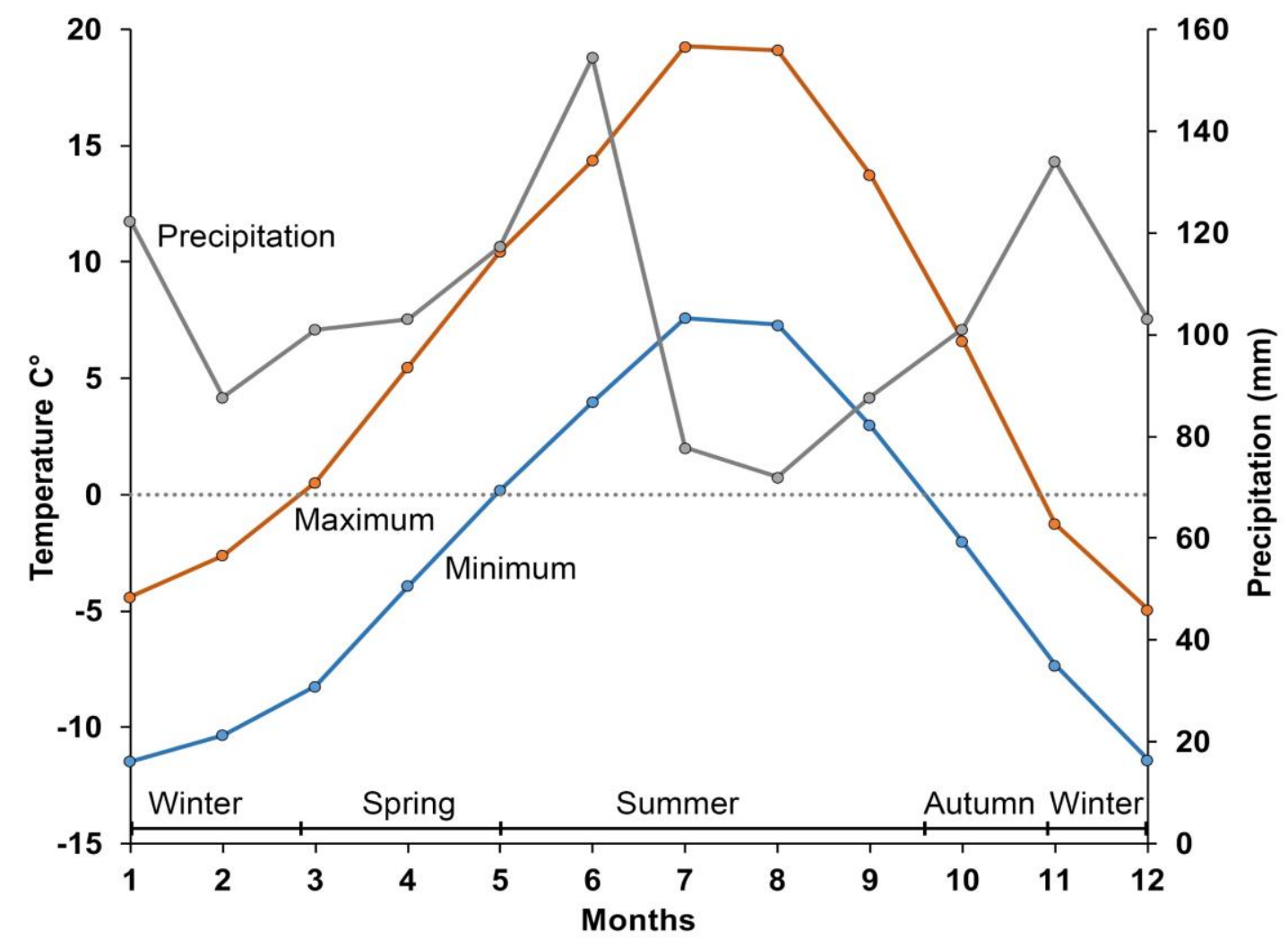

Figure A1. Plot of monthly mean minimum and maximum air temperature, and monthly precipitation over Glacier National Park. The numbers correspond to the month of the year, for example, January is 1 , February is 2 , etc. Winter months include December, January and February, and are defined by mean winter minimum and maximum temperatures are $\leq 0^{\circ} \mathrm{C}$; summer months are May, June, July, August, and September, when both mean minimum and maximum temperatures are $>0^{\circ} \mathrm{C}$; spring (March and April) and fall (October and November) are months when mean minimum temperature is $\leq 0^{\circ} \mathrm{C}$ and mean maximum temperatures are $>0^{\circ} \mathrm{C}$ above zero 
Table A3. Year and source for all outlines across varying inventories and studies. The historical information was gleaned from multiple sources and compiled by Key et al., 2002. The 1966 outlines were created by the USGS, and all other inventories were created at Portland State University by myself, and the Glacier Research team.

\begin{tabular}{rr}
\hline Year & Source \\
\hline 1850 & Mapped Moraines, USGS \\
1887 & Johnson, 1980 \\
1901 & Carrara \& McGimsey, 1988 \\
1911 & Alden, 1914 \\
1913 & Alden, 1914 \\
1927 & Carrara \& McGimsey, 1988 \\
1937 & Dyson \& Gibson, 1939 \\
1938 & Dyson, 1940 \\
1950 & Dyson, 1948 \\
1959 & Baden, 1952 \\
1960 & Johnson, 1980 \\
1966 & Johnson, 1980 \\
1979 & USGS Aerial Photos \\
1991 & USGS Aerial Photos \\
1995 & NAIP DOQ's \\
1998 & NAIP DOQ's \\
2003 & USGS Aerial Photos \\
2005 & NAIP DOQ's \\
2013 & NAIP DOQ's \\
2015 & NAIP DOQ's \\
& Wigital Globe
\end{tabular}




\section{Inventory Data (Appendix B)}

Table A4. Area and topographic characteristics from each inventory. Data includes Glacier Name, RECNO is the unique identifier (Fountain et al., 2007), G or PS defines if a feature is a glacier or perennial snowfield based on shear stress calculations, Area is the area of each feature in $\mathrm{km}^{2}$, Uncert is the uncertainty of each feature in $\mathrm{km}^{2}$, Mean Elevation, Slope, and Aspect are derived from the 1966 National Elevation Dataset digital elevation model and the 2015 LiDAR digital elevation model.

1966

\begin{tabular}{|c|c|c|c|c|c|c|}
\hline Glacier Name & RECNO & $\begin{array}{r}\text { Area } \\
\left(\mathrm{km}^{2}\right)\end{array}$ & $\begin{array}{r}\text { Uncert } \\
\left(\mathrm{km}^{2}\right)\end{array}$ & $\begin{array}{r}\text { Mean } \\
\text { Elevation }\end{array}$ & Slope & Aspect \\
\hline & 1000 & 0.027 & 0.002 & 2793 & 33.4 & 28.9 \\
\hline & 1001 & 0.006 & 0.001 & 2419 & 59.8 & 356.5 \\
\hline & 1002 & 0.012 & 0.001 & 2467 & 62.2 & 13.6 \\
\hline & 1003 & 0.012 & 0.001 & 2701 & 32.9 & 130.5 \\
\hline & 1004 & 0.108 & 0.010 & 2375 & 12.9 & 103.2 \\
\hline & 1005 & 0.068 & 0.006 & 1994 & 27.6 & 34.2 \\
\hline & 1006 & 0.017 & 0.002 & 2096 & 27.5 & 327.1 \\
\hline & 1007 & 0.013 & 0.001 & 2241 & 37.2 & 6.3 \\
\hline & 1008 & 0.070 & 0.006 & 2288 & 53.8 & 1.1 \\
\hline & 1009 & 0.004 & 0.000 & 2080 & 22.2 & 37.9 \\
\hline & 1010 & 0.014 & 0.001 & 2051 & 32.0 & 38.7 \\
\hline & 1011 & 0.025 & 0.002 & 2214 & 40.7 & 4.5 \\
\hline & 1012 & 0.023 & 0.002 & 2404 & 30.0 & 37.1 \\
\hline \multirow[t]{16}{*}{ Herbst Glacier } & 1013 & 0.131 & 0.012 & 2245 & 32.2 & 59.4 \\
\hline & 1014 & 0.003 & 0.000 & 2188 & 21.9 & 68.5 \\
\hline & 1015 & 0.019 & 0.002 & 2459 & 41.3 & 45.7 \\
\hline & 1016 & 0.015 & 0.001 & 2559 & 38.0 & 41.9 \\
\hline & 1017 & 0.051 & 0.005 & 2311 & 40.9 & 332.2 \\
\hline & 1018 & 0.007 & 0.001 & 2199 & 55.2 & 292.6 \\
\hline & 1019 & 0.013 & 0.001 & 2169 & 47.3 & 302.7 \\
\hline & 1020 & 0.011 & 0.001 & 2322 & 41.6 & 192.4 \\
\hline & 1021 & 0.153 & 0.014 & 1713 & 19.8 & 49.6 \\
\hline & 1022 & 0.008 & 0.001 & 2191 & 26.0 & 342.5 \\
\hline & 1023 & 0.081 & 0.007 & 2173 & 20.9 & 63.7 \\
\hline & 1024 & 0.118 & 0.011 & 2293 & 25.3 & 352.5 \\
\hline & 1025 & 0.048 & 0.004 & 1647 & 35.2 & 344.2 \\
\hline & 1026 & 0.349 & 0.031 & 2443 & 42.2 & 356.2 \\
\hline & 1027 & 0.028 & 0.003 & 2352 & 42.2 & 342.1 \\
\hline & 1028 & 0.018 & 0.002 & 1905 & 45.9 & 15.6 \\
\hline \multirow[t]{2}{*}{ Hudson Glacier } & 1029 & 0.087 & 0.008 & 2142 & 41.3 & 10.7 \\
\hline & 1030 & 0.003 & 0.000 & 2001 & 42.5 & 353.5 \\
\hline
\end{tabular}




\begin{tabular}{|c|c|c|c|c|c|c|}
\hline Glacier Name & RECNO & $\begin{array}{r}\text { Area } \\
\left(\mathrm{km}^{2}\right)\end{array}$ & $\begin{array}{r}\text { Uncert } \\
\left(\mathbf{k m}^{2}\right)\end{array}$ & $\begin{array}{r}\text { Mean } \\
\text { Elevation }\end{array}$ & Slope & Aspect \\
\hline & 1031 & 0.022 & 0.002 & 2139 & 28.5 & 354.9 \\
\hline & 1032 & 0.031 & 0.003 & 2455 & 2.5 & 264.5 \\
\hline & 1033 & 0.011 & 0.001 & 2301 & 46.0 & 1.5 \\
\hline & 1034 & 0.009 & 0.001 & 2084 & 47.1 & 21.4 \\
\hline & 1035 & 0.060 & 0.005 & 1943 & 30.4 & 75.3 \\
\hline & 1036 & 0.012 & 0.001 & 2346 & 47.8 & 12.9 \\
\hline & 1037 & 0.002 & 0.000 & 2344 & 49.0 & 332.8 \\
\hline & 1038 & 0.013 & 0.001 & 2137 & 45.1 & 64.2 \\
\hline & 1039 & 0.032 & 0.003 & 2367 & 45.7 & 10.3 \\
\hline & 1040 & 0.035 & 0.003 & 2076 & 38.2 & 80.2 \\
\hline \multirow[t]{3}{*}{ Boulder Glacier } & 1041 & 0.231 & 0.021 & 2369 & 25.7 & 15.4 \\
\hline & 1042 & 0.101 & 0.009 & 2470 & 21.5 & 318.4 \\
\hline & 1043 & 0.021 & 0.002 & 2438 & 32.4 & 27.0 \\
\hline \multirow[t]{11}{*}{ Harris Glacier } & 1044 & 0.153 & 0.014 & 1922 & 17.3 & 5.2 \\
\hline & 1045 & 0.157 & 0.014 & 2257 & 29.0 & 48.3 \\
\hline & 1046 & 0.007 & 0.001 & 2132 & 35.6 & 30.6 \\
\hline & 1047 & 0.060 & 0.005 & 2364 & 26.9 & 62.5 \\
\hline & 1048 & 0.008 & 0.001 & 2224 & 37.7 & 19.7 \\
\hline & 1049 & 0.144 & 0.013 & 2172 & 9.9 & 44.5 \\
\hline & 1050 & 0.058 & 0.005 & 2766 & 34.2 & 21.8 \\
\hline & 1051 & 0.012 & 0.001 & 2400 & 31.6 & 81.7 \\
\hline & 1052 & 0.078 & 0.007 & 2101 & 24.4 & 44.1 \\
\hline & 1053 & 0.002 & 0.000 & 2071 & 34.7 & 313.6 \\
\hline & 1054 & 0.010 & 0.001 & 2085 & 27.8 & 331.3 \\
\hline \multirow[t]{15}{*}{ Agassiz Glacier } & 1055 & 1.586 & 0.143 & 2376 & 13.6 & 66.0 \\
\hline & 1056 & 0.007 & 0.001 & 2139 & 57.3 & 343.0 \\
\hline & 1057 & 0.004 & 0.000 & 2273 & 11.4 & 22.3 \\
\hline & 1058 & 0.002 & 0.000 & 2133 & 68.1 & 347.8 \\
\hline & 1059 & 0.020 & 0.002 & 2084 & 28.2 & 350.3 \\
\hline & 1060 & 0.174 & 0.016 & 2127 & 31.8 & 32.5 \\
\hline & 1061 & 0.011 & 0.001 & 2196 & 26.4 & 68.2 \\
\hline & 1062 & 0.003 & 0.000 & 2416 & 50.1 & 16.0 \\
\hline & 1063 & 0.006 & 0.001 & 1955 & 38.5 & 355.7 \\
\hline & 1064 & 0.004 & 0.000 & 2518 & 47.3 & 26.9 \\
\hline & 1065 & 0.014 & 0.001 & 2195 & 40.1 & 6.1 \\
\hline & 1066 & 0.010 & 0.001 & 2246 & 39.8 & 336.6 \\
\hline & 1067 & 0.018 & 0.002 & 2364 & 8.1 & 318.4 \\
\hline & 1068 & 0.118 & 0.011 & 2172 & 32.0 & 336.5 \\
\hline & 1069 & 0.034 & 0.003 & 2117 & 40.1 & 338.7 \\
\hline
\end{tabular}




\begin{tabular}{|c|c|c|c|c|c|c|}
\hline Glacier Name & RECNO & $\begin{array}{r}\text { Area } \\
\left(\mathrm{km}^{2}\right)\end{array}$ & $\begin{array}{r}\text { Uncert } \\
\left(\mathbf{k m}^{2}\right)\end{array}$ & $\begin{array}{r}\text { Mean } \\
\text { Elevation }\end{array}$ & Slope & Aspect \\
\hline \multirow{4}{*}{ Kintla Glacier } & 1070 & 0.004 & 0.000 & 2571 & 35.6 & 87.6 \\
\hline & 1071 & 0.087 & 0.008 & 2109 & 24.0 & 43.3 \\
\hline & 1072 & 1.274 & 0.115 & 2579 & 17.1 & 13.6 \\
\hline & 1073 & 0.273 & 0.025 & 2548 & 27.5 & 328.5 \\
\hline \multirow[t]{15}{*}{ Miche Waburn } & 1074 & 0.202 & 0.018 & 2208 & 31.0 & 12.1 \\
\hline & 1075 & 0.006 & 0.001 & 2215 & 31.5 & 31.3 \\
\hline & 1076 & 0.021 & 0.002 & 2304 & 49.2 & 14.5 \\
\hline & 1077 & 0.037 & 0.003 & 2259 & 39.9 & 321.0 \\
\hline & 1078 & 0.004 & 0.000 & 2415 & 9.2 & 0.5 \\
\hline & 1079 & 0.058 & 0.005 & 2365 & 34.1 & 22.4 \\
\hline & 1080 & 0.022 & 0.002 & 2324 & 17.3 & 34.3 \\
\hline & 1081 & 0.124 & 0.011 & 2378 & 31.2 & 327.1 \\
\hline & 1082 & 0.004 & 0.000 & 2507 & 30.0 & 10.8 \\
\hline & 1083 & 0.010 & 0.001 & 2471 & 30.9 & 356.4 \\
\hline & 1084 & 0.179 & 0.016 & 2643 & 31.8 & 56.5 \\
\hline & 1085 & 0.065 & 0.006 & 2207 & 28.0 & 62.5 \\
\hline & 1086 & 0.021 & 0.002 & 2669 & 35.3 & 97.7 \\
\hline & 1087 & 0.013 & 0.001 & 2264 & 36.9 & 1.4 \\
\hline & 1088 & 0.191 & 0.017 & 2120 & 18.3 & 13.4 \\
\hline \multirow[t]{5}{*}{ Thunderbird Glacier } & 1089 & 0.133 & 0.012 & 2288 & 22.1 & 44.4 \\
\hline & 1090 & 0.005 & 0.000 & 2430 & 43.7 & 91.1 \\
\hline & 1091 & 0.082 & 0.007 & 2421 & 38.1 & 86.7 \\
\hline & 1092 & 0.002 & 0.000 & 2564 & 61.5 & 78.6 \\
\hline & 1093 & 0.029 & 0.003 & 2411 & 38.5 & 352.6 \\
\hline \multirow[t]{15}{*}{ Dixon Glacier } & 1094 & 0.294 & 0.026 & 2263 & 24.3 & 20.2 \\
\hline & 1095 & 0.037 & 0.003 & 2239 & 34.3 & 309.9 \\
\hline & 1096 & 0.080 & 0.007 & 2334 & 23.0 & 327.9 \\
\hline & 1097 & 0.069 & 0.006 & 1890 & 24.5 & 102.9 \\
\hline & 1098 & 0.007 & 0.001 & 2053 & 38.8 & 350.0 \\
\hline & 1099 & 0.012 & 0.001 & 2033 & 33.1 & 278.8 \\
\hline & 1100 & 0.008 & 0.001 & 1987 & 43.3 & 297.7 \\
\hline & 1101 & 0.018 & 0.002 & 2765 & 38.6 & 152.4 \\
\hline & 1102 & 0.070 & 0.006 & 2022 & 41.4 & 354.2 \\
\hline & 1103 & 0.004 & 0.000 & 1997 & 60.9 & 274.6 \\
\hline & 1104 & 0.022 & 0.002 & 2875 & 47.8 & 95.6 \\
\hline & 1105 & 0.009 & 0.001 & 2572 & 37.8 & 96.2 \\
\hline & 1106 & 0.012 & 0.001 & 3109 & 50.8 & 110.6 \\
\hline & 1107 & 0.004 & 0.000 & 2042 & 29.2 & 10.6 \\
\hline & 1108 & 0.088 & 0.008 & 2133 & 32.0 & 128.1 \\
\hline
\end{tabular}




\begin{tabular}{|c|c|c|c|c|c|c|}
\hline Glacier Name & RECNO & $\begin{array}{r}\text { Area } \\
\left(\mathrm{km}^{2}\right)\end{array}$ & $\begin{array}{r}\text { Uncert } \\
\left(\mathbf{k m}^{2}\right)\end{array}$ & $\begin{array}{r}\text { Mean } \\
\text { Elevation }\end{array}$ & Slope & Aspect \\
\hline & 1109 & 0.060 & 0.005 & 2030 & 25.9 & 24.0 \\
\hline & 1110 & 0.198 & 0.018 & 2400 & 31.7 & 6.9 \\
\hline & 1111 & 0.005 & 0.000 & 2328 & 40.3 & 161.9 \\
\hline & 1112 & 0.007 & 0.001 & 2129 & 42.2 & 343.3 \\
\hline & 1113 & 0.037 & 0.003 & 2270 & 36.3 & 18.8 \\
\hline & 1114 & 0.016 & 0.001 & 2292 & 41.1 & 108.1 \\
\hline & 1115 & 0.023 & 0.002 & 2073 & 33.9 & 106.7 \\
\hline & 1116 & 0.005 & 0.000 & 1980 & 40.1 & 130.7 \\
\hline & 1117 & 0.006 & 0.001 & 2477 & 47.6 & 41.2 \\
\hline \multirow[t]{2}{*}{ Whitecrow Glacier } & 1118 & 0.242 & 0.022 & 2004 & 19.9 & 93.1 \\
\hline & 1119 & 0.012 & 0.001 & 2518 & 52.2 & 1.7 \\
\hline \multirow[t]{6}{*}{ Baby Glacier } & 1120 & 0.113 & 0.010 & 2067 & 20.5 & 59.9 \\
\hline & 1121 & 0.008 & 0.001 & 2160 & 35.4 & 187.3 \\
\hline & 1122 & 0.008 & 0.001 & 2136 & 26.9 & 159.1 \\
\hline & 1123 & 0.018 & 0.002 & 2374 & 43.1 & 68.6 \\
\hline & 1124 & 0.004 & 0.000 & 2201 & 51.0 & 155.8 \\
\hline & 1125 & 0.008 & 0.001 & 2267 & 35.7 & 135.6 \\
\hline \multicolumn{7}{|l|}{ Weasel Collar } \\
\hline \multirow[t]{6}{*}{ Glacier } & 1126 & 0.558 & 0.050 & 2185 & 8.8 & 15.5 \\
\hline & 1127 & 0.072 & 0.006 & 2296 & 20.8 & 346.7 \\
\hline & 1128 & 0.035 & 0.003 & 2590 & 37.7 & 42.5 \\
\hline & 1129 & 0.149 & 0.013 & 1790 & 25.1 & 1.8 \\
\hline & 1130 & 0.023 & 0.002 & 2245 & 30.5 & 92.4 \\
\hline & 1131 & 0.046 & 0.004 & 1899 & 32.6 & 354.4 \\
\hline \multirow[t]{9}{*}{ Carter Glaciers } & 1132 & 0.274 & 0.025 & 2359 & 18.9 & 40.3 \\
\hline & 1133 & 0.034 & 0.003 & 2270 & 27.3 & 109.2 \\
\hline & 1134 & 0.060 & 0.005 & 1970 & 26.2 & 342.3 \\
\hline & 1135 & 0.006 & 0.001 & 2428 & 28.7 & 64.4 \\
\hline & 1136 & 0.004 & 0.000 & 2664 & 34.6 & 175.4 \\
\hline & 1137 & 0.008 & 0.001 & 2596 & 32.7 & 185.5 \\
\hline & 1138 & 0.010 & 0.001 & 2614 & 27.4 & 331.5 \\
\hline & 1139 & 0.010 & 0.001 & 2297 & 37.3 & 105.1 \\
\hline & 1140 & 0.067 & 0.006 & 2512 & 26.6 & 164.6 \\
\hline \multirow[t]{6}{*}{ Rainbow Glacier } & 1141 & 1.213 & 0.109 & 2495 & 11.2 & 96.4 \\
\hline & 1142 & 0.003 & 0.000 & 2489 & 36.3 & 176.7 \\
\hline & 1143 & 0.046 & 0.004 & 2268 & 22.4 & 54.5 \\
\hline & 1144 & 0.027 & 0.002 & 2238 & 28.1 & 85.7 \\
\hline & 1145 & 0.004 & 0.000 & 2467 & 20.7 & 155.0 \\
\hline & 1146 & 0.049 & 0.004 & 2479 & 37.2 & 38.5 \\
\hline
\end{tabular}




\begin{tabular}{|c|c|c|c|c|c|c|}
\hline Glacier Name & RECNO & $\begin{array}{l}\text { Area } \\
\left(\mathrm{km}^{2}\right)\end{array}$ & $\begin{array}{r}\text { Uncert } \\
\left(\mathbf{k m}^{2}\right)\end{array}$ & $\begin{array}{r}\text { Mean } \\
\text { Elevation }\end{array}$ & Slope & Aspect \\
\hline & 1147 & 0.003 & 0.000 & 2362 & 43.9 & 32.8 \\
\hline & 1148 & 0.072 & 0.006 & 2185 & 20.2 & 18.7 \\
\hline & 1149 & 0.019 & 0.002 & 2198 & 34.2 & 16.6 \\
\hline & 1150 & 0.335 & 0.030 & 2316 & 20.8 & 70.2 \\
\hline \multirow[t]{5}{*}{ Carter Glaciers } & 1151 & 0.193 & 0.017 & 2198 & 17.7 & 94.7 \\
\hline & 1152 & 0.021 & 0.002 & 2164 & 23.6 & 33.1 \\
\hline & 1153 & 0.014 & 0.001 & 2059 & 42.5 & 12.7 \\
\hline & 1154 & 0.028 & 0.003 & 2128 & 44.7 & 357.2 \\
\hline & 1155 & 0.077 & 0.007 & 2345 & 28.8 & 346.1 \\
\hline \multirow[t]{8}{*}{ Old Sun Glacier } & 1156 & 0.421 & 0.038 & 2673 & 16.8 & 97.3 \\
\hline & 1157 & 0.050 & 0.004 & 2242 & 32.8 & 359.1 \\
\hline & 1158 & 0.003 & 0.000 & 1931 & 25.8 & 88.4 \\
\hline & 1159 & 0.003 & 0.000 & 2147 & 32.1 & 46.2 \\
\hline & 1160 & 0.051 & 0.005 & 2221 & 30.1 & 102.3 \\
\hline & 1161 & 0.002 & 0.000 & 2427 & 35.5 & 355.7 \\
\hline & 1162 & 0.018 & 0.002 & 2272 & 38.2 & 166.3 \\
\hline & 1163 & 0.006 & 0.001 & 2908 & 43.6 & 12.5 \\
\hline \multirow[t]{21}{*}{ Shepard Glacier } & 1164 & 0.200 & 0.018 & 2330 & 33.4 & 68.5 \\
\hline & 1165 & 0.004 & 0.000 & 2290 & 41.4 & 133.5 \\
\hline & 1166 & 0.017 & 0.001 & 1986 & 34.7 & 232.7 \\
\hline & 1167 & 0.013 & 0.001 & 2243 & 31.7 & 52.6 \\
\hline & 1168 & 0.025 & 0.002 & 2217 & 4.4 & 8.9 \\
\hline & 1169 & 0.005 & 0.000 & 2981 & 35.9 & 59.8 \\
\hline & 1170 & 0.008 & 0.001 & 2249 & 14.6 & 74.0 \\
\hline & 1171 & 0.009 & 0.001 & 2355 & 23.3 & 85.0 \\
\hline & 1172 & 0.283 & 0.025 & 1738 & 25.4 & 56.9 \\
\hline & 1173 & 0.004 & 0.000 & 2266 & 6.0 & 319.8 \\
\hline & 1174 & 0.003 & 0.000 & 2265 & 9.0 & 41.3 \\
\hline & 1175 & 0.005 & 0.000 & 2125 & 38.4 & 65.6 \\
\hline & 1176 & 0.124 & 0.011 & 2333 & 40.3 & 354.9 \\
\hline & 1177 & 0.002 & 0.000 & 2290 & 7.6 & 31.2 \\
\hline & 1178 & 0.013 & 0.001 & 2314 & 14.8 & 34.0 \\
\hline & 1179 & 0.006 & 0.000 & 2269 & 8.4 & 69.4 \\
\hline & 1180 & 0.003 & 0.000 & 2311 & 16.6 & 116.9 \\
\hline & 1181 & 0.003 & 0.000 & 2223 & 29.4 & 110.0 \\
\hline & 1182 & 0.002 & 0.000 & 1991 & 30.6 & 67.7 \\
\hline & 1183 & 0.016 & 0.001 & 2214 & 50.1 & 357.7 \\
\hline & 1184 & 0.006 & 0.000 & 2192 & 34.6 & 36.0 \\
\hline Chaney Glacier & 1185 & 0.535 & 0.048 & 2252 & 17.9 & 26.6 \\
\hline
\end{tabular}




\begin{tabular}{|c|c|c|c|c|c|c|}
\hline Glacier Name & RECNO & $\begin{array}{r}\text { Area } \\
\left(\mathrm{km}^{2}\right)\end{array}$ & $\begin{array}{r}\text { Uncert } \\
\left(\mathbf{k m}^{2}\right)\end{array}$ & $\begin{array}{r}\text { Mean } \\
\text { Elevation }\end{array}$ & Slope & Aspect \\
\hline & 1186 & 0.011 & 0.001 & 2046 & 35.2 & 25.1 \\
\hline & 1187 & 0.003 & 0.000 & 2176 & 25.8 & 91.0 \\
\hline & 1188 & 0.003 & 0.000 & 2049 & 54.1 & 356.5 \\
\hline & 1189 & 0.015 & 0.001 & 2122 & 42.1 & 316.4 \\
\hline & 1190 & 0.151 & 0.014 & 2149 & 29.0 & 57.6 \\
\hline & 1191 & 0.003 & 0.000 & 2178 & 38.2 & 275.1 \\
\hline & 1192 & 0.029 & 0.003 & 2071 & 40.6 & 7.3 \\
\hline & 1193 & 0.024 & 0.002 & 2735 & 47.0 & 126.7 \\
\hline & 1194 & 0.006 & 0.001 & 2103 & 38.8 & 18.3 \\
\hline \multirow[t]{6}{*}{ Ipasha Glacier } & 1195 & 0.320 & 0.029 & 2288 & 20.8 & 26.8 \\
\hline & 1196 & 0.025 & 0.002 & 2038 & 30.3 & 30.0 \\
\hline & 1197 & 0.007 & 0.001 & 2021 & 38.5 & 332.5 \\
\hline & 1198 & 0.004 & 0.000 & 2013 & 26.6 & 332.7 \\
\hline & 1199 & 0.087 & 0.008 & 2492 & 29.8 & 297.0 \\
\hline & 1200 & 0.014 & 0.001 & 2111 & 45.9 & 354.7 \\
\hline Two Ocean Glacier & 1201 & 0.432 & 0.039 & 2585 & 15.1 & 92.1 \\
\hline \multirow[t]{22}{*}{ Ahern Glacier } & 1202 & 0.581 & 0.052 & 2489 & 12.0 & 85.2 \\
\hline & 1203 & 0.015 & 0.001 & 2197 & 38.6 & 142.0 \\
\hline & 1204 & 0.007 & 0.001 & 2684 & 43.3 & 103.1 \\
\hline & 1205 & 0.005 & 0.000 & 2403 & 36.0 & 308.4 \\
\hline & 1206 & 0.014 & 0.001 & 1983 & 21.7 & 131.8 \\
\hline & 1207 & 0.027 & 0.002 & 2300 & 12.5 & 40.4 \\
\hline & 1208 & 0.011 & 0.001 & 2410 & 31.7 & 306.8 \\
\hline & 1209 & 0.171 & 0.015 & 2528 & 19.5 & 63.1 \\
\hline & 1210 & 0.007 & 0.001 & 2666 & 35.0 & 72.8 \\
\hline & 1211 & 0.002 & 0.000 & 2644 & 34.8 & 143.1 \\
\hline & 1212 & 0.064 & 0.006 & 2267 & 25.0 & 68.3 \\
\hline & 1213 & 0.018 & 0.002 & 2405 & 20.1 & 55.8 \\
\hline & 1214 & 0.016 & 0.001 & 2485 & 17.5 & 206.6 \\
\hline & 1215 & 0.006 & 0.001 & 2482 & 25.9 & 191.6 \\
\hline & 1216 & 0.023 & 0.002 & 2644 & 31.0 & 125.4 \\
\hline & 1217 & 0.006 & 0.001 & 2562 & 23.8 & 111.1 \\
\hline & 1218 & 0.006 & 0.001 & 2526 & 25.7 & 195.5 \\
\hline & 1219 & 0.028 & 0.002 & 2475 & 18.6 & 4.8 \\
\hline & 1220 & 0.015 & 0.001 & 2512 & 9.7 & 172.9 \\
\hline & 1221 & 0.010 & 0.001 & 2431 & 26.9 & 86.3 \\
\hline & 1222 & 0.033 & 0.003 & 2502 & 22.7 & 186.4 \\
\hline & 1223 & 0.003 & 0.000 & 1875 & 49.3 & 341.9 \\
\hline Vulture Glacier & 1224 & 0.361 & 0.032 & 2565 & 32.0 & 81.9 \\
\hline
\end{tabular}




\begin{tabular}{|c|c|c|c|c|c|c|}
\hline Glacier Name & RECNO & $\begin{array}{r}\text { Area } \\
\left(\mathrm{km}^{2}\right)\end{array}$ & $\begin{array}{r}\text { Uncert } \\
\left(\mathbf{k m}^{2}\right)\end{array}$ & $\begin{array}{r}\text { Mean } \\
\text { Elevation }\end{array}$ & Slope & Aspect \\
\hline & 1225 & 0.008 & 0.001 & 2199 & 45.8 & 104.4 \\
\hline & 1226 & 0.002 & 0.000 & 1952 & 54.5 & 24.0 \\
\hline & 1227 & 0.133 & 0.012 & 1785 & 31.5 & 74.5 \\
\hline & 1228 & 0.021 & 0.002 & 1971 & 44.0 & 6.8 \\
\hline & 1229 & 0.033 & 0.003 & 2703 & 33.3 & 142.8 \\
\hline & 1230 & 0.014 & 0.001 & 2214 & 26.7 & 61.6 \\
\hline & 1231 & 0.047 & 0.004 & 1730 & 21.0 & 17.5 \\
\hline & 1232 & 0.016 & 0.001 & 2059 & 15.5 & 93.0 \\
\hline & 1233 & 0.014 & 0.001 & 2140 & 35.5 & 41.1 \\
\hline & 1234 & 0.010 & 0.001 & 2519 & 42.3 & 133.1 \\
\hline & 1235 & 0.003 & 0.000 & 1763 & 37.2 & 351.4 \\
\hline & 1236 & 0.025 & 0.002 & 2269 & 30.2 & 142.9 \\
\hline & 1237 & 0.046 & 0.004 & 2284 & 30.1 & 30.0 \\
\hline & 1238 & 0.036 & 0.003 & 2089 & 48.5 & 340.0 \\
\hline & 1239 & 0.019 & 0.002 & 1975 & 33.3 & 136.7 \\
\hline & 1240 & 0.121 & 0.011 & 1878 & 9.7 & 78.0 \\
\hline & 1241 & 0.007 & 0.001 & 1897 & 11.0 & 271.7 \\
\hline & 1242 & 0.005 & 0.000 & 2191 & 19.4 & 19.0 \\
\hline & 1243 & 0.008 & 0.001 & 2090 & 44.6 & 110.3 \\
\hline & 1244 & 0.025 & 0.002 & 1881 & 26.7 & 318.5 \\
\hline & 1245 & 0.003 & 0.000 & 1928 & 31.0 & 310.9 \\
\hline & 1246 & 0.022 & 0.002 & 2035 & 38.3 & 62.7 \\
\hline & 1247 & 0.012 & 0.001 & 2132 & 15.3 & 57.2 \\
\hline & 1248 & 0.010 & 0.001 & 2178 & 14.4 & 46.9 \\
\hline & 1249 & 0.083 & 0.007 & 2084 & 31.9 & 40.3 \\
\hline & 1250 & 0.067 & 0.006 & 2255 & 37.0 & 99.6 \\
\hline & 1251 & 0.006 & 0.001 & 2070 & 6.7 & 67.6 \\
\hline & 1252 & 0.003 & 0.000 & 2068 & 6.9 & 60.9 \\
\hline & 1253 & 0.061 & 0.006 & 2179 & 27.7 & 32.2 \\
\hline & 1254 & 0.055 & 0.005 & 2115 & 43.9 & 14.5 \\
\hline & 1255 & 0.015 & 0.001 & 2385 & 48.4 & 51.5 \\
\hline & 1256 & 0.026 & 0.002 & 1976 & 26.5 & 30.4 \\
\hline & 1257 & 0.040 & 0.004 & 2258 & 22.6 & 93.4 \\
\hline & 1258 & 0.034 & 0.003 & 2172 & 13.5 & 52.0 \\
\hline \multirow[t]{5}{*}{ Swiftcurrent Glacier } & 1259 & 0.175 & 0.016 & 2231 & 40.6 & 28.1 \\
\hline & 1260 & 0.009 & 0.001 & 2243 & 17.2 & 6.8 \\
\hline & 1261 & 0.070 & 0.006 & 2219 & 34.2 & 334.3 \\
\hline & 1262 & 0.007 & 0.001 & 2048 & 6.2 & 335.8 \\
\hline & 1263 & 0.009 & 0.001 & 2304 & 37.4 & 65.8 \\
\hline
\end{tabular}




\begin{tabular}{|c|c|c|c|c|c|c|}
\hline Glacier Name & RECNO & $\begin{array}{r}\text { Area } \\
\left(\mathrm{km}^{2}\right)\end{array}$ & $\begin{array}{r}\text { Uncert } \\
\left(\mathbf{k m}^{2}\right)\end{array}$ & $\begin{array}{r}\text { Mean } \\
\text { Elevation }\end{array}$ & Slope & Aspect \\
\hline & 1264 & 0.024 & 0.002 & 2120 & 28.5 & 338.3 \\
\hline & 1265 & 0.010 & 0.001 & 2188 & 33.8 & 69.7 \\
\hline & 1266 & 0.065 & 0.006 & 2294 & 18.9 & 6.5 \\
\hline & 1267 & 0.011 & 0.001 & 1926 & 17.3 & 113.5 \\
\hline & 1268 & 0.102 & 0.009 & 2097 & 23.3 & 45.6 \\
\hline & 1269 & 0.004 & 0.000 & 2243 & 30.3 & 154.5 \\
\hline & 1270 & 0.022 & 0.002 & 2211 & 20.9 & 39.9 \\
\hline \multirow[t]{6}{*}{ Salamander Glacier } & 1271 & 0.226 & 0.020 & 2196 & 16.6 & 107.0 \\
\hline & 1272 & 0.008 & 0.001 & 2471 & 41.2 & 34.7 \\
\hline & 1273 & 0.006 & 0.001 & 1995 & 28.2 & 130.6 \\
\hline & 1274 & 0.031 & 0.003 & 2390 & 46.1 & 349.7 \\
\hline & 1275 & 0.018 & 0.002 & 1903 & 10.2 & 12.1 \\
\hline & 1276 & 0.004 & 0.000 & 2172 & 39.7 & 84.2 \\
\hline \multirow[t]{6}{*}{ Grinnell Glacier } & 1277 & 1.018 & 0.092 & 2025 & 7.4 & 14.2 \\
\hline & 1278 & 0.017 & 0.002 & 2635 & 41.1 & 65.6 \\
\hline & 1279 & 0.011 & 0.001 & 2257 & 37.3 & 103.4 \\
\hline & 1280 & 0.034 & 0.003 & 2220 & 34.8 & 359.8 \\
\hline & 1281 & 0.035 & 0.003 & 2058 & 39.4 & 276.3 \\
\hline & 1282 & 0.039 & 0.003 & 2379 & 36.6 & 144.7 \\
\hline \multirow[t]{13}{*}{ Gem Glacier } & 1283 & 0.021 & 0.002 & 2511 & 38.6 & 36.0 \\
\hline & 1284 & 0.039 & 0.004 & 2017 & 21.0 & 50.4 \\
\hline & 1285 & 0.056 & 0.005 & 1977 & 43.7 & 329.5 \\
\hline & 1286 & 0.016 & 0.001 & 2146 & 35.2 & 92.3 \\
\hline & 1287 & 0.028 & 0.003 & 2646 & 42.4 & 356.7 \\
\hline & 1288 & 0.047 & 0.004 & 1730 & 25.6 & 92.8 \\
\hline & 1289 & 0.013 & 0.001 & 1837 & 33.7 & 341.1 \\
\hline & 1290 & 0.008 & 0.001 & 2110 & 25.6 & 341.7 \\
\hline & 1291 & 0.083 & 0.007 & 2166 & 16.9 & 94.8 \\
\hline & 1292 & 0.027 & 0.002 & 2144 & 26.0 & 98.4 \\
\hline & 1293 & 0.026 & 0.002 & 2252 & 38.9 & 356.7 \\
\hline & 1294 & 0.005 & 0.000 & 2117 & 49.4 & 30.1 \\
\hline & 1295 & 0.015 & 0.001 & 2265 & 28.5 & 354.1 \\
\hline \multirow[t]{7}{*}{ Siyeh Glacier } & 1296 & 0.211 & 0.019 & 2106 & 18.5 & 17.0 \\
\hline & 1297 & 0.009 & 0.001 & 2162 & 42.2 & 7.3 \\
\hline & 1298 & 0.022 & 0.002 & 2205 & 37.9 & 8.3 \\
\hline & 1299 & 0.017 & 0.002 & 2270 & 48.6 & 4.6 \\
\hline & 1300 & 0.037 & 0.003 & 2639 & 39.0 & 99.5 \\
\hline & 1301 & 0.005 & 0.000 & 2420 & 39.3 & 133.9 \\
\hline & 1302 & 0.031 & 0.003 & 2325 & 35.6 & 97.1 \\
\hline
\end{tabular}




\begin{tabular}{|c|c|c|c|c|c|c|}
\hline Glacier Name & RECNO & $\begin{array}{r}\text { Area } \\
\left(\mathrm{km}^{2}\right)\end{array}$ & $\begin{array}{r}\text { Uncert } \\
\left(\mathbf{k m}^{2}\right)\end{array}$ & $\begin{array}{r}\text { Mean } \\
\text { Elevation }\end{array}$ & Slope & Aspect \\
\hline & 1303 & 0.020 & 0.002 & 2039 & 42.7 & 64.3 \\
\hline & 1304 & 0.013 & 0.001 & 2036 & 26.1 & 71.0 \\
\hline & 1305 & 0.093 & 0.008 & 1974 & 20.4 & 27.3 \\
\hline & 1306 & 0.012 & 0.001 & 2021 & 20.4 & 327.5 \\
\hline & 1307 & 0.026 & 0.002 & 2326 & 33.0 & 107.8 \\
\hline & 1308 & 0.264 & 0.024 & 2118 & 24.6 & 35.0 \\
\hline & 1309 & 0.007 & 0.001 & 2058 & 58.9 & 48.2 \\
\hline & 1310 & 0.022 & 0.002 & 2307 & 27.3 & 40.4 \\
\hline & 1311 & 0.003 & 0.000 & 2222 & 16.8 & 144.9 \\
\hline & 1312 & 0.020 & 0.002 & 2272 & 30.0 & 353.4 \\
\hline & 1313 & 0.045 & 0.004 & 2323 & 30.9 & 117.4 \\
\hline & 1314 & 0.007 & 0.001 & 2511 & 39.7 & 64.0 \\
\hline & 1315 & 0.089 & 0.008 & 2214 & 21.3 & 93.1 \\
\hline & 1316 & 0.110 & 0.010 & 1898 & 28.3 & 83.7 \\
\hline & 1317 & 0.023 & 0.002 & 2207 & 35.7 & 356.3 \\
\hline & 1318 & 0.038 & 0.003 & 2618 & 23.1 & 37.0 \\
\hline & 1319 & 0.033 & 0.003 & 2315 & 27.5 & 10.4 \\
\hline & 1320 & 0.011 & 0.001 & 2466 & 23.6 & 93.1 \\
\hline & 1321 & 0.033 & 0.003 & 2181 & 35.7 & 78.0 \\
\hline & 1322 & 0.033 & 0.003 & 2340 & 24.4 & 151.5 \\
\hline \multirow[t]{6}{*}{ Piegan Glacier } & 1323 & 0.280 & 0.025 & 2512 & 16.4 & 54.3 \\
\hline & 1324 & 0.019 & 0.002 & 2205 & 11.7 & 146.5 \\
\hline & 1325 & 0.018 & 0.002 & 2471 & 45.2 & 128.1 \\
\hline & 1326 & 0.095 & 0.009 & 2071 & 21.0 & 94.6 \\
\hline & 1327 & 0.012 & 0.001 & 2276 & 16.9 & 148.6 \\
\hline & 1328 & 0.010 & 0.001 & 2239 & 2.1 & 121.6 \\
\hline \multirow[t]{13}{*}{ Sexton Glacier } & 1329 & 0.397 & 0.036 & 2225 & 24.2 & 76.3 \\
\hline & 1330 & 0.041 & 0.004 & 2171 & 27.1 & 64.7 \\
\hline & 1331 & 0.007 & 0.001 & 2284 & 28.9 & 136.7 \\
\hline & 1332 & 0.022 & 0.002 & 2348 & 39.3 & 113.4 \\
\hline & 1333 & 0.017 & 0.002 & 2142 & 40.5 & 123.4 \\
\hline & 1334 & 0.017 & 0.002 & 2089 & 41.1 & 359.0 \\
\hline & 1335 & 0.021 & 0.002 & 2414 & 30.2 & 51.6 \\
\hline & 1336 & 0.020 & 0.002 & 1728 & 28.2 & 357.5 \\
\hline & 1337 & 0.022 & 0.002 & 2547 & 43.5 & 9.0 \\
\hline & 1338 & 0.025 & 0.002 & 2189 & 24.5 & 58.1 \\
\hline & 1339 & 0.081 & 0.007 & 2013 & 31.1 & 8.7 \\
\hline & 1340 & 0.071 & 0.006 & 2096 & 23.7 & 345.6 \\
\hline & 1341 & 0.014 & 0.001 & 2123 & 26.7 & 49.5 \\
\hline
\end{tabular}




\begin{tabular}{|c|c|c|c|c|c|c|}
\hline Glacier Name & RECNO & $\begin{array}{r}\text { Area } \\
\left(\mathrm{km}^{2}\right)\end{array}$ & $\begin{array}{r}\text { Uncert } \\
\left(\mathbf{k m}^{2}\right)\end{array}$ & $\begin{array}{r}\text { Mean } \\
\text { Elevation }\end{array}$ & Slope & Aspect \\
\hline & 1342 & 0.011 & 0.001 & 1941 & 31.2 & 105.0 \\
\hline & 1343 & 0.153 & 0.014 & 2240 & 26.9 & 113.0 \\
\hline & 1344 & 0.012 & 0.001 & 2257 & 36.5 & 47.4 \\
\hline & 1345 & 0.006 & 0.000 & 2204 & 23.7 & 28.9 \\
\hline & 1346 & 0.022 & 0.002 & 2058 & 26.8 & 4.4 \\
\hline & 1347 & 0.066 & 0.006 & 2357 & 34.2 & 358.4 \\
\hline & 1348 & 0.006 & 0.001 & 2081 & 50.2 & 5.9 \\
\hline & 1349 & 0.003 & 0.000 & 2062 & 48.3 & 359.1 \\
\hline & 1350 & 0.013 & 0.001 & 1769 & 38.9 & 52.7 \\
\hline & 1351 & 0.007 & 0.001 & 1841 & 31.6 & 62.1 \\
\hline & 1352 & 0.090 & 0.008 & 2624 & 41.4 & 36.3 \\
\hline & 1353 & 0.069 & 0.006 & 2275 & 25.7 & 76.2 \\
\hline & 1354 & 0.010 & 0.001 & 2234 & 27.3 & 96.4 \\
\hline & 1355 & 0.011 & 0.001 & 2556 & 17.4 & 86.1 \\
\hline & 1356 & 0.019 & 0.002 & 2385 & 12.0 & 6.7 \\
\hline & 1357 & 0.020 & 0.002 & 2399 & 40.5 & 134.3 \\
\hline & 1358 & 0.004 & 0.000 & 2286 & 14.1 & 354.5 \\
\hline & 1359 & 0.004 & 0.000 & 2297 & 21.6 & 0.0 \\
\hline & 1360 & 0.015 & 0.001 & 2343 & 39.3 & 11.5 \\
\hline & 1361 & 0.113 & 0.010 & 2076 & 34.5 & 38.5 \\
\hline & 1362 & 0.160 & 0.014 & 2132 & 23.5 & 56.5 \\
\hline & 1363 & 0.004 & 0.000 & 1921 & 57.6 & 28.4 \\
\hline & 1364 & 0.004 & 0.000 & 1985 & 51.4 & 36.8 \\
\hline & 1365 & 0.003 & 0.000 & 1926 & 48.0 & 349.3 \\
\hline & 1366 & 0.011 & 0.001 & 1998 & 57.8 & 10.6 \\
\hline & 1367 & 0.018 & 0.002 & 2392 & 26.9 & 359.9 \\
\hline & 1368 & 0.006 & 0.001 & 2520 & 37.5 & 60.2 \\
\hline & 1369 & 0.003 & 0.000 & 2037 & 55.9 & 340.6 \\
\hline & 1370 & 0.010 & 0.001 & 2210 & 36.8 & 4.0 \\
\hline & 1371 & 0.005 & 0.000 & 2111 & 50.0 & 12.0 \\
\hline & 1372 & 0.017 & 0.002 & 2293 & 19.4 & 357.8 \\
\hline & 1373 & 0.011 & 0.001 & 2362 & 27.4 & 94.9 \\
\hline & 1374 & 0.011 & 0.001 & 2333 & 22.9 & 152.4 \\
\hline & 1375 & 0.069 & 0.006 & 2460 & 26.1 & 109.8 \\
\hline & 1376 & 0.055 & 0.005 & 2198 & 36.9 & 24.2 \\
\hline & 1377 & 0.005 & 0.000 & 2357 & 47.2 & 300.5 \\
\hline & 1378 & 0.037 & 0.003 & 2370 & 49.9 & 24.2 \\
\hline & 1379 & 0.277 & 0.025 & 2340 & 8.0 & 72.4 \\
\hline & 1380 & 0.048 & 0.004 & 2510 & 38.0 & 118.0 \\
\hline
\end{tabular}




\begin{tabular}{|c|c|c|c|c|c|c|}
\hline Glacier Name & RECNO & $\begin{array}{r}\text { Area } \\
\left(\mathrm{km}^{2}\right)\end{array}$ & $\begin{array}{r}\text { Uncert } \\
\left(\mathbf{k m}^{2}\right)\end{array}$ & $\begin{array}{r}\text { Mean } \\
\text { Elevation }\end{array}$ & Slope & Aspect \\
\hline & 1381 & 0.003 & 0.000 & 2494 & 36.6 & 3.0 \\
\hline & 1382 & 0.004 & 0.000 & 2575 & 43.5 & 301.1 \\
\hline & 1383 & 0.004 & 0.000 & 2550 & 44.0 & 323.6 \\
\hline & 1384 & 0.120 & 0.011 & 2414 & 23.1 & 35.6 \\
\hline & 1385 & 0.023 & 0.002 & 2053 & 31.4 & 41.9 \\
\hline & 1386 & 0.036 & 0.003 & 2373 & 25.8 & 65.4 \\
\hline & 1387 & 0.005 & 0.000 & 2353 & 33.1 & 88.1 \\
\hline & 1388 & 0.076 & 0.007 & 2403 & 32.0 & 104.8 \\
\hline & 1389 & 0.010 & 0.001 & 2166 & 29.3 & 109.9 \\
\hline & 1390 & 0.013 & 0.001 & 2354 & 37.4 & 46.5 \\
\hline & 1391 & 0.026 & 0.002 & 2354 & 38.6 & 23.0 \\
\hline & 1392 & 0.025 & 0.002 & 2246 & 36.5 & 12.0 \\
\hline & 1393 & 0.029 & 0.003 & 2463 & 31.2 & 7.4 \\
\hline & 1394 & 0.006 & 0.001 & 2173 & 29.1 & 111.3 \\
\hline & 1395 & 0.098 & 0.009 & 2284 & 28.6 & 89.6 \\
\hline & 1396 & 0.021 & 0.002 & 2463 & 39.3 & 266.4 \\
\hline & 1397 & 0.012 & 0.001 & 2498 & 31.5 & 64.6 \\
\hline & 1398 & 0.046 & 0.004 & 2192 & 41.5 & 10.2 \\
\hline & 1399 & 0.012 & 0.001 & 2129 & 30.2 & 28.6 \\
\hline & 1400 & 0.008 & 0.001 & 2392 & 36.9 & 140.8 \\
\hline & 1401 & 0.008 & 0.001 & 2488 & 29.9 & 52.5 \\
\hline & 1402 & 0.020 & 0.002 & 2276 & 28.7 & 157.3 \\
\hline & 1403 & 0.040 & 0.004 & 2284 & 22.3 & 297.5 \\
\hline & 1404 & 0.007 & 0.001 & 2010 & 28.8 & 51.0 \\
\hline & 1405 & 0.003 & 0.000 & 2442 & 46.4 & 57.7 \\
\hline & 1406 & 0.007 & 0.001 & 2190 & 26.8 & 61.5 \\
\hline & 1407 & 0.009 & 0.001 & 2048 & 19.5 & 66.5 \\
\hline & 1408 & 0.016 & 0.001 & 2314 & 32.4 & 344.0 \\
\hline & 1409 & 0.013 & 0.001 & 2255 & 34.7 & 149.1 \\
\hline & 1410 & 0.010 & 0.001 & 2001 & 24.2 & 78.1 \\
\hline & 1411 & 0.013 & 0.001 & 2219 & 29.5 & 64.4 \\
\hline & 1412 & 0.004 & 0.000 & 2158 & 22.4 & 75.0 \\
\hline & 1413 & 0.099 & 0.009 & 2479 & 45.5 & 6.8 \\
\hline \multirow[t]{6}{*}{ Jackson Glacier } & 1414 & 1.255 & 0.113 & 2180 & 22.9 & 32.9 \\
\hline & 1415 & 0.003 & 0.000 & 2203 & 30.4 & 72.7 \\
\hline & 1416 & 0.004 & 0.000 & 2374 & 38.4 & 66.1 \\
\hline & 1417 & 0.004 & 0.000 & 2100 & 22.5 & 81.8 \\
\hline & 1418 & 0.014 & 0.001 & 2488 & 36.6 & 52.8 \\
\hline & 1419 & 0.110 & 0.010 & 2399 & 31.0 & 322.6 \\
\hline
\end{tabular}




\begin{tabular}{|c|c|c|c|c|c|c|}
\hline Glacier Name & RECNO & $\begin{array}{r}\text { Area } \\
\left(\mathrm{km}^{2}\right)\end{array}$ & $\begin{array}{r}\text { Uncert } \\
\left(\mathbf{k m}^{2}\right)\end{array}$ & $\begin{array}{r}\text { Mean } \\
\text { Elevation }\end{array}$ & Slope & Aspect \\
\hline & 1420 & 0.014 & 0.001 & 2075 & 15.9 & 76.1 \\
\hline & 1421 & 0.458 & 0.041 & 2274 & 29.7 & 316.4 \\
\hline & 1422 & 0.020 & 0.002 & 2038 & 17.5 & 61.0 \\
\hline \multirow[t]{7}{*}{ Logan Glacier } & 1423 & 0.503 & 0.045 & 2213 & 23.4 & 38.3 \\
\hline & 1424 & 0.221 & 0.020 & 2498 & 30.4 & 323.3 \\
\hline & 1425 & 0.004 & 0.000 & 2675 & 46.5 & 78.9 \\
\hline & 1426 & 0.011 & 0.001 & 2337 & 42.2 & 351.0 \\
\hline & 1427 & 0.004 & 0.000 & 2853 & 40.1 & 345.3 \\
\hline & 1428 & 0.014 & 0.001 & 2658 & 38.6 & 87.6 \\
\hline & 1429 & 0.027 & 0.002 & 2771 & 30.8 & 85.6 \\
\hline \multirow[t]{17}{*}{ Blackfoot Glacier } & 1430 & 1.755 & 0.158 & 2288 & 16.6 & 20.5 \\
\hline & 1431 & 0.032 & 0.003 & 2418 & 36.6 & 286.4 \\
\hline & 1432 & 0.052 & 0.005 & 2789 & 45.5 & 165.1 \\
\hline & 1433 & 0.002 & 0.000 & 2572 & 43.4 & 107.3 \\
\hline & 1434 & 0.006 & 0.001 & 2221 & 26.3 & 298.2 \\
\hline & 1435 & 0.187 & 0.017 & 2136 & 22.4 & 12.1 \\
\hline & 1436 & 0.005 & 0.000 & 2286 & 35.0 & 280.3 \\
\hline & 1437 & 0.018 & 0.002 & 2023 & 38.3 & 300.9 \\
\hline & 1438 & 0.003 & 0.000 & 2256 & 30.8 & 316.6 \\
\hline & 1439 & 0.007 & 0.001 & 2597 & 46.8 & 168.0 \\
\hline & 1440 & 0.005 & 0.000 & 2001 & 41.0 & 325.1 \\
\hline & 1441 & 0.139 & 0.013 & 2434 & 36.5 & 341.4 \\
\hline & 1442 & 0.012 & 0.001 & 2481 & 34.9 & 59.6 \\
\hline & 1443 & 0.456 & 0.041 & 2395 & 21.5 & 117.7 \\
\hline & 1444 & 0.058 & 0.005 & 2502 & 40.6 & 15.0 \\
\hline & 1445 & 0.049 & 0.004 & 2336 & 35.5 & 319.3 \\
\hline & 1446 & 0.004 & 0.000 & 2289 & 26.6 & 227.5 \\
\hline \multirow[t]{12}{*}{ Red Eagle Glacier } & 1447 & 0.181 & 0.016 & 2156 & 22.1 & 32.2 \\
\hline & 1448 & 0.076 & 0.007 & 2429 & 38.5 & 312.8 \\
\hline & 1449 & 0.011 & 0.001 & 2523 & 32.3 & 350.1 \\
\hline & 1450 & 0.052 & 0.005 & 2223 & 21.1 & 133.5 \\
\hline & 1451 & 0.004 & 0.000 & 2487 & 53.9 & 7.7 \\
\hline & 1452 & 0.005 & 0.000 & 2321 & 33.2 & 125.4 \\
\hline & 1453 & 0.007 & 0.001 & 2454 & 35.1 & 170.8 \\
\hline & 1454 & 0.004 & 0.000 & 2245 & 30.5 & 120.0 \\
\hline & 1455 & 0.035 & 0.003 & 2373 & 20.8 & 148.0 \\
\hline & 1456 & 0.005 & 0.000 & 2203 & 24.4 & 158.3 \\
\hline & 1457 & 0.157 & 0.014 & 2418 & 9.6 & 70.9 \\
\hline & 1458 & 0.006 & 0.001 & 2280 & 25.8 & 133.4 \\
\hline
\end{tabular}




\begin{tabular}{|c|c|c|c|c|c|c|}
\hline Glacier Name & RECNO & $\begin{array}{r}\text { Area } \\
\left(\mathrm{km}^{2}\right)\end{array}$ & $\begin{array}{r}\text { Uncert } \\
\left(\mathbf{k m}^{2}\right) \\
\end{array}$ & $\begin{array}{r}\text { Mean } \\
\text { Elevation }\end{array}$ & Slope & Aspect \\
\hline & 1459 & 0.005 & 0.000 & 2513 & 34.0 & 92.9 \\
\hline & 1460 & 0.003 & 0.000 & 2312 & 13.5 & 113.8 \\
\hline & 1461 & 0.006 & 0.001 & 2267 & 22.2 & 135.5 \\
\hline & 1462 & 0.022 & 0.002 & 2494 & 15.7 & 226.9 \\
\hline & 1463 & 0.002 & 0.000 & 2260 & 34.6 & 209.9 \\
\hline & 1464 & 0.005 & 0.000 & 2157 & 24.1 & 148.3 \\
\hline & 1465 & 0.012 & 0.001 & 2459 & 14.4 & 218.1 \\
\hline \multirow[t]{32}{*}{ Pumpelly Glacier } & 1466 & 0.943 & 0.085 & 2527 & 24.8 & 78.2 \\
\hline & 1467 & 0.006 & 0.001 & 2255 & 9.2 & 105.9 \\
\hline & 1468 & 0.022 & 0.002 & 2165 & 23.6 & 64.2 \\
\hline & 1469 & 0.004 & 0.000 & 2209 & 9.4 & 122.9 \\
\hline & 1470 & 0.010 & 0.001 & 2055 & 18.0 & 163.3 \\
\hline & 1471 & 0.101 & 0.009 & 2663 & 28.2 & 346.2 \\
\hline & 1472 & 0.094 & 0.008 & 2527 & 29.6 & 333.7 \\
\hline & 1473 & 0.044 & 0.004 & 2157 & 24.4 & 128.2 \\
\hline & 1474 & 0.003 & 0.000 & 2168 & 6.1 & 95.7 \\
\hline & 1475 & 0.003 & 0.000 & 2214 & 17.1 & 260.3 \\
\hline & 1476 & 0.171 & 0.015 & 2212 & 20.2 & 31.1 \\
\hline & 1477 & 0.041 & 0.004 & 2140 & 16.6 & 31.3 \\
\hline & 1478 & 0.010 & 0.001 & 1839 & 48.7 & 350.2 \\
\hline & 1479 & 0.097 & 0.009 & 2112 & 37.3 & 287.9 \\
\hline & 1480 & 0.068 & 0.006 & 2181 & 30.4 & 358.8 \\
\hline & 1481 & 0.006 & 0.001 & 2059 & 33.9 & 72.3 \\
\hline & 1482 & 0.095 & 0.009 & 2031 & 17.1 & 14.6 \\
\hline & 1483 & 0.007 & 0.001 & 2330 & 44.1 & 354.9 \\
\hline & 1484 & 0.028 & 0.003 & 2248 & 15.0 & 64.5 \\
\hline & 1485 & 0.014 & 0.001 & 2813 & 42.2 & 103.4 \\
\hline & 1486 & 0.005 & 0.000 & 2386 & 38.2 & 332.9 \\
\hline & 1487 & 0.027 & 0.002 & 2481 & 34.8 & 175.3 \\
\hline & 1488 & 0.013 & 0.001 & 2256 & 36.9 & 66.6 \\
\hline & 1489 & 0.006 & 0.001 & 2758 & 40.4 & 142.3 \\
\hline & 1490 & 0.015 & 0.001 & 2349 & 33.7 & 48.6 \\
\hline & 1491 & 0.166 & 0.015 & 2089 & 9.6 & 1.0 \\
\hline & 1492 & 0.019 & 0.002 & 1905 & 13.8 & 67.4 \\
\hline & 1493 & 0.026 & 0.002 & 2337 & 34.2 & 131.8 \\
\hline & 1494 & 0.032 & 0.003 & 2076 & 23.6 & 150.8 \\
\hline & 1495 & 0.047 & 0.004 & 2173 & 35.4 & 138.3 \\
\hline & 1496 & 0.007 & 0.001 & 1852 & 14.1 & 57.1 \\
\hline & 1497 & 0.004 & 0.000 & 2137 & 16.1 & 122.3 \\
\hline
\end{tabular}




\begin{tabular}{|c|c|c|c|c|c|c|}
\hline Glacier Name & RECNO & $\begin{array}{r}\text { Area } \\
\left(\mathbf{k m}^{2}\right)\end{array}$ & $\begin{array}{r}\text { Uncert } \\
\left(\mathbf{k m}^{2}\right)\end{array}$ & $\begin{array}{r}\text { Mean } \\
\text { Elevation }\end{array}$ & Slope & Aspect \\
\hline & 1498 & 0.003 & 0.000 & 2182 & 26.8 & 108.7 \\
\hline & 1499 & 0.002 & 0.000 & 2116 & 21.7 & 133.0 \\
\hline & 1500 & 0.005 & 0.000 & 2171 & 21.3 & 90.4 \\
\hline & 1501 & 0.003 & 0.000 & 2195 & 20.1 & 103.8 \\
\hline & 1502 & 0.010 & 0.001 & 2251 & 32.2 & 63.9 \\
\hline & 1503 & 0.009 & 0.001 & 2514 & 30.0 & 86.8 \\
\hline & 1504 & 0.009 & 0.001 & 2398 & 26.2 & 64.1 \\
\hline & 1505 & 0.011 & 0.001 & 2649 & 18.9 & 77.3 \\
\hline & 1506 & 0.120 & 0.011 & 2222 & 24.9 & 18.3 \\
\hline & 1507 & 0.014 & 0.001 & 2555 & 28.3 & 117.6 \\
\hline & 1508 & 0.014 & 0.001 & 2472 & 30.9 & 122.5 \\
\hline & 1509 & 0.050 & 0.004 & 2260 & 8.2 & 138.1 \\
\hline & 1510 & 0.058 & 0.005 & 1986 & 28.2 & 16.6 \\
\hline & 1511 & 0.013 & 0.001 & 2393 & 30.0 & 112.6 \\
\hline & 1512 & 0.017 & 0.002 & 2000 & 40.1 & 329.5 \\
\hline & 1513 & 0.107 & 0.010 & 2262 & 25.6 & 79.5 \\
\hline & 1514 & 0.066 & 0.006 & 2388 & 18.2 & 81.8 \\
\hline & 1515 & 0.157 & 0.014 & 2211 & 16.9 & 30.8 \\
\hline & 1516 & 0.035 & 0.003 & 2356 & 9.3 & 66.3 \\
\hline & 1517 & 0.039 & 0.004 & 2170 & 47.9 & 354.7 \\
\hline & 1518 & 0.098 & 0.009 & 2117 & 14.8 & 61.3 \\
\hline & 1519 & 0.007 & 0.001 & 2332 & 25.7 & 333.3 \\
\hline & 1520 & 0.034 & 0.003 & 2285 & 28.7 & 122.4 \\
\hline & 1521 & 0.007 & 0.001 & 2339 & 42.1 & 342.0 \\
\hline & 1522 & 0.005 & 0.000 & 1846 & 36.3 & 128.3 \\
\hline & 1523 & 0.013 & 0.001 & 2294 & 29.4 & 75.5 \\
\hline & 1524 & 0.010 & 0.001 & 2291 & 28.1 & 44.3 \\
\hline & 1525 & 0.033 & 0.003 & 2269 & 16.8 & 26.6 \\
\hline & 1526 & 0.050 & 0.004 & 1860 & 23.9 & 23.9 \\
\hline & 1527 & 0.004 & 0.000 & 2341 & 47.9 & 7.5 \\
\hline & 1528 & 0.032 & 0.003 & 2210 & 30.1 & 79.0 \\
\hline & 1529 & 0.011 & 0.001 & 2428 & 49.0 & 4.0 \\
\hline & 1530 & 0.008 & 0.001 & 2484 & 42.6 & 5.2 \\
\hline & 1531 & 0.030 & 0.003 & 1900 & 22.1 & 67.3 \\
\hline & 1532 & 0.004 & 0.000 & 2312 & 26.7 & 60.5 \\
\hline & 1533 & 0.012 & 0.001 & 2717 & 40.1 & 45.2 \\
\hline & 1534 & 0.226 & 0.020 & 2022 & 8.0 & 51.5 \\
\hline & 1535 & 0.053 & 0.005 & 1992 & 45.6 & 325.0 \\
\hline & 1536 & 0.036 & 0.003 & 2073 & 14.5 & 37.6 \\
\hline
\end{tabular}




\begin{tabular}{|c|c|c|c|c|c|c|}
\hline Glacier Name & RECNO & $\begin{array}{r}\text { Area } \\
\left(\mathrm{km}^{2}\right)\end{array}$ & $\begin{array}{r}\text { Uncert } \\
\left(\mathbf{k m}^{2}\right)\end{array}$ & $\begin{array}{r}\text { Mean } \\
\text { Elevation }\end{array}$ & Slope & Aspect \\
\hline & 1537 & 0.004 & 0.000 & 1993 & 12.7 & 56.9 \\
\hline & 1538 & 0.011 & 0.001 & 2019 & 34.8 & 61.3 \\
\hline & 1539 & 0.015 & 0.001 & 1757 & 25.7 & 66.1 \\
\hline & 1540 & 0.050 & 0.005 & 1927 & 28.0 & 51.2 \\
\hline & 1541 & 0.022 & 0.002 & 1760 & 30.8 & 354.9 \\
\hline & 1542 & 0.003 & 0.000 & 2034 & 49.3 & 26.4 \\
\hline & 1543 & 0.159 & 0.014 & 2016 & 44.9 & 21.2 \\
\hline & 1544 & 0.006 & 0.001 & 2340 & 63.5 & 33.8 \\
\hline & 1545 & 0.010 & 0.001 & 2197 & 38.4 & 332.4 \\
\hline & 1546 & 0.011 & 0.001 & 2309 & 42.7 & 342.9 \\
\hline & 1547 & 0.046 & 0.004 & 2040 & 16.6 & 1.1 \\
\hline & 1548 & 0.004 & 0.000 & 2417 & 44.8 & 76.4 \\
\hline & 1549 & 0.006 & 0.001 & 2250 & 65.5 & 21.2 \\
\hline & 1550 & 0.004 & 0.000 & 2291 & 39.8 & 65.7 \\
\hline & 1551 & 0.008 & 0.001 & 2221 & 29.8 & 18.7 \\
\hline & 1552 & 0.013 & 0.001 & 2092 & 29.9 & 29.1 \\
\hline & 1553 & 0.002 & 0.000 & 2294 & 30.1 & 32.3 \\
\hline & 1554 & 0.012 & 0.001 & 2386 & 42.2 & 94.9 \\
\hline \multirow[t]{21}{*}{ Lupfer Glacier } & 1555 & 0.138 & 0.012 & 1868 & 30.6 & 94.9 \\
\hline & 1556 & 0.024 & 0.002 & 1895 & 27.2 & 70.2 \\
\hline & 1557 & 0.051 & 0.005 & 2107 & 20.3 & 43.8 \\
\hline & 1558 & 0.008 & 0.001 & 1692 & 31.6 & 49.5 \\
\hline & 1559 & 0.005 & 0.000 & 2052 & 56.5 & 40.5 \\
\hline & 1560 & 0.034 & 0.003 & 2097 & 19.7 & 11.5 \\
\hline & 1561 & 0.092 & 0.008 & 2262 & 19.8 & 48.6 \\
\hline & 1562 & 0.004 & 0.000 & 2102 & 34.4 & 357.8 \\
\hline & 1563 & 0.020 & 0.002 & 2333 & 28.7 & 43.8 \\
\hline & 1564 & 0.012 & 0.001 & 2112 & 35.7 & 105.4 \\
\hline & 1565 & 0.011 & 0.001 & 2638 & 42.7 & 47.3 \\
\hline & 1566 & 0.020 & 0.002 & 2539 & 36.1 & 23.7 \\
\hline & 1567 & 0.023 & 0.002 & 1972 & 12.5 & 116.7 \\
\hline & 1568 & 0.114 & 0.010 & 2270 & 28.9 & 73.8 \\
\hline & 1569 & 0.026 & 0.002 & 2084 & 30.5 & 127.1 \\
\hline & 1570 & 0.014 & 0.001 & 2170 & 20.0 & 12.0 \\
\hline & 1571 & 0.008 & 0.001 & 2361 & 25.7 & 96.7 \\
\hline & 1572 & 0.046 & 0.004 & 2446 & 21.4 & 10.9 \\
\hline & 1573 & 0.094 & 0.008 & 1944 & 22.3 & 16.4 \\
\hline & 1574 & 0.003 & 0.000 & 2567 & 35.4 & 351.0 \\
\hline & 1575 & 0.013 & 0.001 & 2183 & 24.6 & 2.7 \\
\hline
\end{tabular}




\begin{tabular}{rrrrrrr}
\hline Glacier Name & RECNO & $\begin{array}{r}\text { Area } \\
\left(\mathbf{k m}^{2} \mathbf{)}\right.\end{array}$ & $\begin{array}{r}\text { Uncert } \\
\mathbf{( k m}^{2} \mathbf{)}\end{array}$ & $\begin{array}{r}\text { Mean } \\
\text { Elevation }\end{array}$ & Slope & Aspect \\
\hline & 1576 & 0.003 & 0.000 & 2172 & 2.1 & 359.8 \\
& 1577 & 0.002 & 0.000 & 2191 & 19.5 & 346.3 \\
& 1578 & 0.019 & 0.002 & 2089 & 33.1 & 9.0 \\
& 1579 & 0.017 & 0.002 & 2334 & 26.8 & 351.0 \\
& 1580 & 0.033 & 0.003 & 2556 & 32.2 & 5.7 \\
& 1581 & 0.025 & 0.002 & 2219 & 18.4 & 55.8 \\
& 1582 & 0.060 & 0.005 & 2079 & 27.7 & 30.8 \\
& 1583 & 0.036 & 0.003 & 2198 & 39.4 & 50.1 \\
& 1584 & 0.007 & 0.001 & 2188 & 26.9 & 164.7 \\
& 1585 & 0.005 & 0.000 & 2258 & 43.4 & 74.5 \\
& 1586 & 0.002 & 0.000 & 2170 & 34.3 & 54.6 \\
& 1587 & 0.001 & 0.000 & 2063 & 26.7 & 322.3 \\
& 1588 & 0.464 & 0.042 & 2420 & 9.7 & 358.1 \\
Sperry Glacier & 1589 & 1.281 & 0.115 & 2384 & 14.3 & 3.0 \\
& 1590 & 0.044 & 0.004 & 2719 & 26.8 & 121.8 \\
& 1591 & 0.001 & 0.000 & 2332 & 33.1 & 75.2 \\
Grant Glacier & 1593 & 0.343 & 0.031 & 2412 & 21.1 & 71.4 \\
& 1594 & 0.001 & 0.000 & 2407 & 42.9 & 59.1 \\
& 1595 & 0.003 & 0.000 & 2107 & 41.1 & 64.2 \\
& 1596 & 0.005 & 0.000 & 2424 & 10.3 & 353.7 \\
& 1597 & 0.015 & 0.001 & 2163 & 17.8 & 9.3 \\
& 1598 & 0.025 & 0.002 & 2231 & 44.0 & 328.9 \\
& 1599 & 0.002 & 0.000 & 2274 & 22.5 & 114.1 \\
& 1600 & 0.006 & 0.001 & 1947 & 2.9 & 325.1 \\
& 1601 & 1.413 & 0.127 & 2492 & 9.5 & 94.7 \\
& 1602 & 0.184 & 0.017 & 2203 & 15.7 & 92.9 \\
& 9980 & 0.182 & 0.016 & 2212 & 12.7 & 97.3
\end{tabular}

1991

\begin{tabular}{rrrrrrr}
\hline Glacier Name & RECNO & $\begin{array}{r}\text { Area } \\
\mathbf{( k m}^{\mathbf{2}}\end{array}$ & $\begin{array}{r}\text { Uncert } \\
\mathbf{( k m}^{\mathbf{2}}\end{array}$ & $\begin{array}{r}\text { Mean } \\
\text { Elevation }\end{array}$ & Slope & Aspect \\
\hline & 1003 & 0.009 & 0.002 & 2701 & 32.9 & 130.5 \\
& 1004 & 0.090 & 0.020 & 2375 & 12.9 & 103.2
\end{tabular}




\begin{tabular}{|c|c|c|c|c|c|c|}
\hline Glacier Name & RECNO & $\begin{array}{r}\text { Area } \\
\left(\mathrm{km}^{2}\right)\end{array}$ & $\begin{array}{r}\text { Uncert } \\
\left(\mathbf{k m}^{2}\right)\end{array}$ & $\begin{array}{r}\text { Mean } \\
\text { Elevation }\end{array}$ & Slope & Aspect \\
\hline & 1005 & 0.040 & 0.009 & 1994 & 27.6 & 34.2 \\
\hline & 1006 & 0.019 & 0.002 & 2096 & 27.5 & 327.1 \\
\hline & 1008 & 0.019 & 0.004 & 2288 & 53.8 & 1.1 \\
\hline & 1010 & 0.008 & 0.002 & 2051 & 32.0 & 38.7 \\
\hline & 1011 & 0.018 & 0.004 & 2214 & 40.7 & 4.5 \\
\hline & 1012 & 0.089 & 0.020 & 2404 & 30.0 & 37.1 \\
\hline & 1014 & 0.012 & 0.003 & 2188 & 21.9 & 68.5 \\
\hline & 1015 & 0.030 & 0.006 & 2459 & 41.3 & 45.7 \\
\hline & 1021 & 0.046 & 0.010 & 1713 & 19.8 & 49.6 \\
\hline & 1022 & 0.045 & 0.010 & 2191 & 26.0 & 342.5 \\
\hline & 1023 & 0.026 & 0.006 & 2173 & 20.9 & 63.7 \\
\hline & 1024 & 0.296 & 0.065 & 2293 & 25.3 & 352.5 \\
\hline & 1027 & 0.078 & 0.017 & 2352 & 42.2 & 342.1 \\
\hline \multirow[t]{9}{*}{ Hudson Glacier } & 1029 & 0.006 & 0.003 & 2142 & 41.3 & 10.7 \\
\hline & 1030 & 0.004 & 0.001 & 2001 & 42.5 & 353.5 \\
\hline & 1032 & 0.006 & 0.002 & 2455 & 2.5 & 264.5 \\
\hline & 1033 & 0.052 & 0.011 & 2301 & 46.0 & 1.5 \\
\hline & 1034 & 0.007 & 0.001 & 2084 & 47.1 & 21.4 \\
\hline & 1037 & 0.009 & 0.002 & 2344 & 49.0 & 332.8 \\
\hline & 1038 & 0.079 & 0.007 & 2137 & 45.1 & 64.2 \\
\hline & 1039 & 0.053 & 0.012 & 2367 & 45.7 & 10.3 \\
\hline & 1040 & 0.008 & 0.002 & 2076 & 38.2 & 80.2 \\
\hline Boulder Glacier & 1041 & 0.056 & 0.012 & 2369 & 25.7 & 15.4 \\
\hline \multirow[t]{6}{*}{ Harris Glacier } & 1044 & 0.040 & 0.009 & 1922 & 17.3 & 5.2 \\
\hline & 1045 & 0.003 & 0.001 & 2257 & 29.0 & 48.3 \\
\hline & 1049 & 0.071 & 0.016 & 2172 & 9.9 & 44.5 \\
\hline & 1051 & 0.004 & 0.001 & 2400 & 31.6 & 81.7 \\
\hline & 1052 & 0.004 & 0.001 & 2101 & 24.4 & 44.1 \\
\hline & 1053 & 1.266 & 0.278 & 2071 & 34.7 & 313.6 \\
\hline \multirow[t]{10}{*}{ Agassiz Glacier } & 1055 & 0.030 & 0.003 & 2376 & 13.6 & 66.0 \\
\hline & 1056 & 0.002 & 0.000 & 2139 & 57.3 & 343.0 \\
\hline & 1057 & 0.017 & 0.004 & 2273 & 11.4 & 22.3 \\
\hline & 1058 & 0.129 & 0.028 & 2133 & 68.1 & 347.8 \\
\hline & 1064 & 0.004 & 0.001 & 2518 & 47.3 & 26.9 \\
\hline & 1065 & 0.006 & 0.001 & 2195 & 40.1 & 6.1 \\
\hline & 1066 & 0.007 & 0.001 & 2246 & 39.8 & 336.6 \\
\hline & 1067 & 0.001 & 0.000 & 2364 & 8.1 & 318.4 \\
\hline & 1068 & 0.063 & 0.026 & 2172 & 32.0 & 336.5 \\
\hline & 1069 & 1.125 & 0.101 & 2117 & 40.1 & 338.7 \\
\hline
\end{tabular}




\begin{tabular}{|c|c|c|c|c|c|c|}
\hline Glacier Name & RECNO & $\begin{array}{r}\text { Area } \\
\left(\mathrm{km}^{2}\right)\end{array}$ & $\begin{array}{r}\text { Uncert } \\
\left(\mathbf{k m}^{2}\right)\end{array}$ & $\begin{array}{r}\text { Mean } \\
\text { Elevation }\end{array}$ & Slope & Aspect \\
\hline \multirow{15}{*}{ Kintla Glacier } & 1070 & 0.091 & 0.020 & 2571 & 35.6 & 87.6 \\
\hline & 1071 & 0.165 & 0.015 & 2109 & 24.0 & 43.3 \\
\hline & 1072 & 0.061 & 0.006 & 2579 & 17.1 & 13.6 \\
\hline & 1073 & 0.042 & 0.009 & 2548 & 27.5 & 328.5 \\
\hline & 1075 & 0.142 & 0.031 & 2215 & 31.5 & 31.3 \\
\hline & 1076 & 0.004 & 0.000 & 2304 & 49.2 & 14.5 \\
\hline & 1078 & 0.004 & 0.001 & 2415 & 9.2 & 0.5 \\
\hline & 1079 & 0.090 & 0.020 & 2365 & 34.1 & 22.4 \\
\hline & 1080 & 0.004 & 0.001 & 2324 & 17.3 & 34.3 \\
\hline & 1081 & 0.027 & 0.006 & 2378 & 31.2 & 327.1 \\
\hline & 1083 & 0.152 & 0.014 & 2471 & 30.9 & 356.4 \\
\hline & 1084 & 0.115 & 0.025 & 2643 & 31.8 & 56.5 \\
\hline & 1085 & 0.018 & 0.002 & 2207 & 28.0 & 62.5 \\
\hline & 1086 & 0.044 & 0.010 & 2669 & 35.3 & 97.7 \\
\hline & 1088 & 0.004 & 0.001 & 2120 & 18.3 & 13.4 \\
\hline \multirow[t]{4}{*}{ Thunderbird Glacier } & 1089 & 0.070 & 0.015 & 2288 & 22.1 & 44.4 \\
\hline & 1090 & 0.179 & 0.039 & 2430 & 43.7 & 91.1 \\
\hline & 1091 & 0.018 & 0.004 & 2421 & 38.1 & 86.7 \\
\hline & 1093 & 0.238 & 0.052 & 2411 & 38.5 & 352.6 \\
\hline \multirow[t]{15}{*}{ Dixon Glacier } & 1094 & 0.015 & 0.001 & 2263 & 24.3 & 20.2 \\
\hline & 1095 & 0.062 & 0.014 & 2239 & 34.3 & 309.9 \\
\hline & 1096 & 0.009 & 0.001 & 2334 & 23.0 & 327.9 \\
\hline & 1098 & 0.061 & 0.014 & 2053 & 38.8 & 350.0 \\
\hline & 1099 & 0.004 & 0.001 & 2033 & 33.1 & 278.8 \\
\hline & 1100 & 0.017 & 0.004 & 1987 & 43.3 & 297.7 \\
\hline & 1101 & 0.015 & 0.003 & 2765 & 38.6 & 152.4 \\
\hline & 1104 & 0.075 & 0.016 & 2875 & 47.8 & 95.6 \\
\hline & 1109 & 0.030 & 0.007 & 2030 & 25.9 & 24.0 \\
\hline & 1112 & 0.218 & 0.020 & 2129 & 42.2 & 343.3 \\
\hline & 1114 & 0.089 & 0.020 & 2292 & 41.1 & 108.1 \\
\hline & 1115 & 0.010 & 0.002 & 2073 & 33.9 & 106.7 \\
\hline & 1116 & 0.007 & 0.003 & 1980 & 40.1 & 130.7 \\
\hline & 1117 & 0.008 & 0.002 & 2477 & 47.6 & 41.2 \\
\hline & 1119 & 0.520 & 0.047 & 2518 & 52.2 & 1.7 \\
\hline \multirow[t]{5}{*}{ Baby Glacier } & 1120 & 0.038 & 0.003 & 2067 & 20.5 & 59.9 \\
\hline & 1121 & 0.014 & 0.003 & 2160 & 35.4 & 187.3 \\
\hline & 1122 & 0.023 & 0.005 & 2136 & 26.9 & 159.1 \\
\hline & 1123 & 0.234 & 0.052 & 2374 & 43.1 & 68.6 \\
\hline & 1124 & 0.044 & 0.010 & 2201 & 51.0 & 155.8 \\
\hline
\end{tabular}




\begin{tabular}{|c|c|c|c|c|c|c|}
\hline Glacier Name & RECNO & $\begin{array}{r}\text { Area } \\
\left(\mathrm{km}^{2}\right)\end{array}$ & $\begin{array}{r}\text { Uncert } \\
\left(\mathbf{k m}^{2}\right)\end{array}$ & $\begin{array}{r}\text { Mean } \\
\text { Elevation }\end{array}$ & Slope & Aspect \\
\hline & 1125 & 0.043 & 0.009 & 2267 & 35.7 & 135.6 \\
\hline \multicolumn{7}{|l|}{ Weasel Collar } \\
\hline \multirow[t]{4}{*}{ Glacier } & 1126 & 0.009 & 0.001 & 2185 & 8.8 & 15.5 \\
\hline & 1129 & 0.007 & 0.002 & 1790 & 25.1 & 1.8 \\
\hline & 1130 & 0.008 & 0.002 & 2245 & 30.5 & 92.4 \\
\hline & 1131 & 0.013 & 0.003 & 1899 & 32.6 & 354.4 \\
\hline \multirow[t]{7}{*}{ Carter Glaciers } & 1132 & 0.041 & 0.009 & 2359 & 18.9 & 40.3 \\
\hline & 1133 & 0.063 & 0.014 & 2270 & 27.3 & 109.2 \\
\hline & 1134 & 1.172 & 0.105 & 1970 & 26.2 & 342.3 \\
\hline & 1136 & 0.028 & 0.006 & 2664 & 34.6 & 175.4 \\
\hline & 1137 & 0.003 & 0.001 & 2596 & 32.7 & 185.5 \\
\hline & 1139 & 0.047 & 0.010 & 2297 & 37.3 & 105.1 \\
\hline & 1140 & 0.052 & 0.011 & 2512 & 26.6 & 164.6 \\
\hline \multirow[t]{5}{*}{ Rainbow Glacier } & 1141 & 0.000 & 0.000 & 2495 & 11.2 & 96.4 \\
\hline & 1143 & 0.155 & 0.034 & 2268 & 22.4 & 54.5 \\
\hline & 1148 & 0.421 & 0.093 & 2185 & 20.2 & 18.7 \\
\hline & 1149 & 0.046 & 0.010 & 2198 & 34.2 & 16.6 \\
\hline & 1150 & 0.001 & 0.000 & 2316 & 20.8 & 70.2 \\
\hline \multirow[t]{2}{*}{ Carter Glaciers } & 1151 & 0.032 & 0.013 & 2198 & 17.7 & 94.7 \\
\hline & 1155 & 0.017 & 0.004 & 2345 & 28.8 & 346.1 \\
\hline \multirow[t]{19}{*}{ Old Sun Glacier } & 1156 & 0.003 & 0.001 & 2673 & 16.8 & 97.3 \\
\hline & 1157 & 0.109 & 0.010 & 2242 & 32.8 & 359.1 \\
\hline & 1159 & 0.025 & 0.006 & 2147 & 32.1 & 46.2 \\
\hline & 1160 & 0.007 & 0.003 & 2221 & 30.1 & 102.3 \\
\hline & 1161 & 0.006 & 0.001 & 2427 & 35.5 & 355.7 \\
\hline & 1162 & 0.010 & 0.002 & 2272 & 38.2 & 166.3 \\
\hline & 1163 & 0.022 & 0.005 & 2908 & 43.6 & 12.5 \\
\hline & 1165 & 0.287 & 0.026 & 2290 & 41.4 & 133.5 \\
\hline & 1166 & 0.003 & 0.001 & 1986 & 34.7 & 232.7 \\
\hline & 1167 & 0.002 & 0.000 & 2243 & 31.7 & 52.6 \\
\hline & 1168 & 0.002 & 0.000 & 2217 & 4.4 & 8.9 \\
\hline & 1169 & 0.101 & 0.022 & 2981 & 35.9 & 59.8 \\
\hline & 1170 & 0.015 & 0.003 & 2249 & 14.6 & 74.0 \\
\hline & 1172 & 0.014 & 0.003 & 1738 & 25.4 & 56.9 \\
\hline & 1174 & 0.002 & 0.000 & 2265 & 9.0 & 41.3 \\
\hline & 1176 & 0.140 & 0.013 & 2333 & 40.3 & 354.9 \\
\hline & 1179 & 0.492 & 0.108 & 2269 & 8.4 & 69.4 \\
\hline & 1180 & 0.011 & 0.002 & 2311 & 16.6 & 116.9 \\
\hline & 1183 & 0.004 & 0.001 & 2214 & 50.1 & 357.7 \\
\hline
\end{tabular}




\begin{tabular}{|c|c|c|c|c|c|c|}
\hline Glacier Name & RECNO & $\begin{array}{r}\text { Area } \\
\left(\mathrm{km}^{2}\right)\end{array}$ & $\begin{array}{r}\text { Uncert } \\
\left(\mathbf{k m}^{2}\right)\end{array}$ & $\begin{array}{r}\text { Mean } \\
\text { Elevation }\end{array}$ & Slope & Aspect \\
\hline \multirow[t]{9}{*}{ Chaney Glacier } & 1185 & 0.007 & 0.002 & 2252 & 17.9 & 26.6 \\
\hline & 1186 & 0.003 & 0.001 & 2046 & 35.2 & 25.1 \\
\hline & 1187 & 0.023 & 0.005 & 2176 & 25.8 & 91.0 \\
\hline & 1188 & 0.291 & 0.064 & 2049 & 54.1 & 356.5 \\
\hline & 1189 & 0.020 & 0.004 & 2122 & 42.1 & 316.4 \\
\hline & 1191 & 0.065 & 0.014 & 2178 & 38.2 & 275.1 \\
\hline & 1192 & 0.343 & 0.031 & 2071 & 40.6 & 7.3 \\
\hline & 1193 & 0.555 & 0.050 & 2735 & 47.0 & 126.7 \\
\hline & 1194 & 0.010 & 0.002 & 2103 & 38.8 & 18.3 \\
\hline \multirow[t]{5}{*}{ Ipasha Glacier } & 1195 & 0.016 & 0.003 & 2288 & 20.8 & 26.8 \\
\hline & 1196 & 0.019 & 0.004 & 2038 & 30.3 & 30.0 \\
\hline & 1197 & 0.005 & 0.001 & 2021 & 38.5 & 332.5 \\
\hline & 1199 & 0.026 & 0.006 & 2492 & 29.8 & 297.0 \\
\hline & 1200 & 0.012 & 0.003 & 2111 & 45.9 & 354.7 \\
\hline \multirow[t]{25}{*}{ Two Ocean Glacier } & 1201 & 0.008 & 0.002 & 2585 & 15.1 & 92.1 \\
\hline & 1203 & 0.007 & 0.001 & 2197 & 38.6 & 142.0 \\
\hline & 1204 & 0.111 & 0.024 & 2684 & 43.3 & 103.1 \\
\hline & 1205 & 0.060 & 0.013 & 2403 & 36.0 & 308.4 \\
\hline & 1206 & 0.015 & 0.003 & 1983 & 21.7 & 131.8 \\
\hline & 1207 & 0.018 & 0.004 & 2300 & 12.5 & 40.4 \\
\hline & 1211 & 0.007 & 0.002 & 2644 & 34.8 & 143.1 \\
\hline & 1213 & 0.029 & 0.006 & 2405 & 20.1 & 55.8 \\
\hline & 1214 & 0.356 & 0.078 & 2485 & 17.5 & 206.6 \\
\hline & 1216 & 0.012 & 0.003 & 2644 & 31.0 & 125.4 \\
\hline & 1217 & 0.031 & 0.007 & 2562 & 23.8 & 111.1 \\
\hline & 1219 & 0.114 & 0.025 & 2475 & 18.6 & 4.8 \\
\hline & 1221 & 0.033 & 0.007 & 2431 & 26.9 & 86.3 \\
\hline & 1222 & 0.044 & 0.004 & 2502 & 22.7 & 186.4 \\
\hline & 1223 & 0.011 & 0.002 & 1875 & 49.3 & 341.9 \\
\hline & 1225 & 0.009 & 0.002 & 2199 & 45.8 & 104.4 \\
\hline & 1227 & 0.017 & 0.004 & 1785 & 31.5 & 74.5 \\
\hline & 1228 & 0.010 & 0.002 & 1971 & 44.0 & 6.8 \\
\hline & 1230 & 0.024 & 0.005 & 2214 & 26.7 & 61.6 \\
\hline & 1231 & 0.025 & 0.006 & 1730 & 21.0 & 17.5 \\
\hline & 1232 & 0.108 & 0.024 & 2059 & 15.5 & 93.0 \\
\hline & 1235 & 0.011 & 0.002 & 1763 & 37.2 & 351.4 \\
\hline & 1237 & 0.033 & 0.003 & 2284 & 30.1 & 30.0 \\
\hline & 1240 & 0.062 & 0.006 & 1878 & 9.7 & 78.0 \\
\hline & 1243 & 0.077 & 0.017 & 2090 & 44.6 & 110.3 \\
\hline
\end{tabular}




\begin{tabular}{|c|c|c|c|c|c|c|}
\hline Glacier Name & RECNO & $\begin{array}{r}\text { Area } \\
\left(\mathrm{km}^{2}\right)\end{array}$ & $\begin{array}{r}\text { Uncert } \\
\left(\mathbf{k m}^{2}\right)\end{array}$ & $\begin{array}{r}\text { Mean } \\
\text { Elevation }\end{array}$ & Slope & Aspect \\
\hline & 1244 & 0.009 & 0.002 & 1881 & 26.7 & 318.5 \\
\hline & 1246 & 0.056 & 0.012 & 2035 & 38.3 & 62.7 \\
\hline & 1247 & 0.012 & 0.003 & 2132 & 15.3 & 57.2 \\
\hline & 1250 & 0.037 & 0.008 & 2255 & 37.0 & 99.6 \\
\hline & 1251 & 0.228 & 0.020 & 2070 & 6.7 & 67.6 \\
\hline & 1252 & 0.012 & 0.003 & 2068 & 6.9 & 60.9 \\
\hline & 1274 & 0.034 & 0.007 & 2390 & 46.1 & 349.7 \\
\hline & 1278 & 0.054 & 0.012 & 2635 & 41.1 & 65.6 \\
\hline & 1279 & 0.018 & 0.004 & 2257 & 37.3 & 103.4 \\
\hline \multirow[t]{30}{*}{ Gem Glacier } & 1283 & 0.085 & 0.008 & 2511 & 38.6 & 36.0 \\
\hline & 1288 & 0.219 & 0.031 & 1730 & 25.6 & 92.8 \\
\hline & 1292 & 0.020 & 0.004 & 2144 & 26.0 & 98.4 \\
\hline & 1293 & 0.031 & 0.007 & 2252 & 38.9 & 356.7 \\
\hline & 1294 & 0.004 & 0.001 & 2117 & 49.4 & 30.1 \\
\hline & 1297 & 0.014 & 0.003 & 2162 & 42.2 & 7.3 \\
\hline & 1299 & 0.027 & 0.006 & 2270 & 48.6 & 4.6 \\
\hline & 1302 & 0.021 & 0.005 & 2325 & 35.6 & 97.1 \\
\hline & 1303 & 0.003 & 0.001 & 2039 & 42.7 & 64.3 \\
\hline & 1304 & 0.015 & 0.003 & 2036 & 26.1 & 71.0 \\
\hline & 1305 & 0.035 & 0.008 & 1974 & 20.4 & 27.3 \\
\hline & 1308 & 0.020 & 0.004 & 2118 & 24.6 & 35.0 \\
\hline & 1311 & 0.010 & 0.002 & 2222 & 16.8 & 144.9 \\
\hline & 1313 & 0.283 & 0.026 & 2323 & 30.9 & 117.4 \\
\hline & 1317 & 0.019 & 0.004 & 2207 & 35.7 & 356.3 \\
\hline & 1319 & 0.400 & 0.088 & 2315 & 27.5 & 10.4 \\
\hline & 1322 & 0.032 & 0.007 & 2340 & 24.4 & 151.5 \\
\hline & 1334 & 0.123 & 0.011 & 2089 & 41.1 & 359.0 \\
\hline & 1337 & 0.050 & 0.011 & 2547 & 43.5 & 9.0 \\
\hline & 1341 & 0.007 & 0.002 & 2123 & 26.7 & 49.5 \\
\hline & 1342 & 0.080 & 0.018 & 1941 & 31.2 & 105.0 \\
\hline & 1343 & 0.014 & 0.003 & 2240 & 26.9 & 113.0 \\
\hline & 1347 & 0.006 & 0.001 & 2357 & 34.2 & 358.4 \\
\hline & 1348 & 0.018 & 0.004 & 2081 & 50.2 & 5.9 \\
\hline & 1349 & 0.007 & 0.002 & 2062 & 48.3 & 359.1 \\
\hline & 1350 & 0.015 & 0.003 & 1769 & 38.9 & 52.7 \\
\hline & 1352 & 0.150 & 0.033 & 2624 & 41.4 & 36.3 \\
\hline & 1353 & 0.005 & 0.001 & 2275 & 25.7 & 76.2 \\
\hline & 1356 & 0.015 & 0.003 & 2385 & 12.0 & 6.7 \\
\hline & 1357 & 0.008 & 0.002 & 2399 & 40.5 & 134.3 \\
\hline
\end{tabular}




\begin{tabular}{|c|c|c|c|c|c|c|}
\hline Glacier Name & RECNO & $\begin{array}{r}\text { Area } \\
\left(\mathrm{km}^{2}\right)\end{array}$ & $\begin{array}{r}\text { Uncert } \\
\left(\mathbf{k m}^{2}\right)\end{array}$ & $\begin{array}{r}\text { Mean } \\
\text { Elevation }\end{array}$ & Slope & Aspect \\
\hline & 1359 & 0.012 & 0.003 & 2297 & 21.6 & 0.0 \\
\hline & 1361 & 0.014 & 0.003 & 2076 & 34.5 & 38.5 \\
\hline & 1363 & 0.014 & 0.001 & 1921 & 57.6 & 28.4 \\
\hline & 1368 & 0.256 & 0.056 & 2520 & 37.5 & 60.2 \\
\hline & 1369 & 0.046 & 0.010 & 2037 & 55.9 & 340.6 \\
\hline & 1370 & 0.003 & 0.001 & 2210 & 36.8 & 4.0 \\
\hline & 1372 & 0.001 & 0.000 & 2293 & 19.4 & 357.8 \\
\hline & 1376 & 0.011 & 0.002 & 2198 & 36.9 & 24.2 \\
\hline & 1377 & 0.032 & 0.007 & 2357 & 47.2 & 300.5 \\
\hline & 1379 & 0.006 & 0.001 & 2340 & 8.0 & 72.4 \\
\hline & 1380 & 0.077 & 0.017 & 2510 & 38.0 & 118.0 \\
\hline & 1384 & 0.096 & 0.021 & 2414 & 23.1 & 35.6 \\
\hline & 1385 & 0.019 & 0.004 & 2053 & 31.4 & 41.9 \\
\hline & 1386 & 0.018 & 0.004 & 2373 & 25.8 & 65.4 \\
\hline & 1387 & 0.008 & 0.002 & 2353 & 33.1 & 88.1 \\
\hline & 1388 & 0.014 & 0.003 & 2403 & 32.0 & 104.8 \\
\hline & 1389 & 0.019 & 0.004 & 2166 & 29.3 & 109.9 \\
\hline & 1390 & 0.031 & 0.007 & 2354 & 37.4 & 46.5 \\
\hline & 1391 & 0.002 & 0.001 & 2354 & 38.6 & 23.0 \\
\hline & 1392 & 0.012 & 0.003 & 2246 & 36.5 & 12.0 \\
\hline & 1393 & 0.015 & 0.003 & 2463 & 31.2 & 7.4 \\
\hline & 1394 & 0.016 & 0.004 & 2173 & 29.1 & 111.3 \\
\hline & 1396 & 0.014 & 0.003 & 2463 & 39.3 & 266.4 \\
\hline & 1397 & 0.026 & 0.006 & 2498 & 31.5 & 64.6 \\
\hline & 1398 & 0.090 & 0.008 & 2192 & 41.5 & 10.2 \\
\hline & 1399 & 1.136 & 0.102 & 2129 & 30.2 & 28.6 \\
\hline & 1402 & 0.004 & 0.001 & 2276 & 28.7 & 157.3 \\
\hline & 1404 & 0.100 & 0.009 & 2010 & 28.8 & 51.0 \\
\hline & 1405 & 0.019 & 0.004 & 2442 & 46.4 & 57.7 \\
\hline & 1408 & 0.204 & 0.018 & 2314 & 32.4 & 344.0 \\
\hline & 1411 & 0.008 & 0.002 & 2219 & 29.5 & 64.4 \\
\hline & 1413 & 0.010 & 0.001 & 2479 & 45.5 & 6.8 \\
\hline & 1415 & 0.016 & 0.004 & 2203 & 30.4 & 72.7 \\
\hline & 1416 & 0.023 & 0.005 & 2374 & 38.4 & 66.1 \\
\hline & 1418 & 0.031 & 0.007 & 2488 & 36.6 & 52.8 \\
\hline & 1420 & 0.051 & 0.011 & 2075 & 15.9 & 76.1 \\
\hline & 1421 & 0.005 & 0.000 & 2274 & 29.7 & 316.4 \\
\hline \multirow[t]{2}{*}{ Logan Glacier } & 1423 & 0.002 & 0.000 & 2213 & 23.4 & 38.3 \\
\hline & 1424 & 0.017 & 0.004 & 2498 & 30.4 & 323.3 \\
\hline
\end{tabular}




\begin{tabular}{|c|c|c|c|c|c|c|}
\hline Glacier Name & RECNO & $\begin{array}{r}\text { Area } \\
\left(\mathrm{km}^{2}\right)\end{array}$ & $\begin{array}{r}\text { Uncert } \\
\left(\mathbf{k m}^{2}\right)\end{array}$ & $\begin{array}{r}\text { Mean } \\
\text { Elevation }\end{array}$ & Slope & Aspect \\
\hline & 1425 & 0.005 & 0.001 & 2675 & 46.5 & 78.9 \\
\hline & 1427 & 0.008 & 0.002 & 2853 & 40.1 & 345.3 \\
\hline & 1428 & 0.128 & 0.012 & 2658 & 38.6 & 87.6 \\
\hline & 1429 & 0.009 & 0.002 & 2771 & 30.8 & 85.6 \\
\hline \multirow[t]{35}{*}{ Blackfoot Glacier } & 1430 & 0.007 & 0.002 & 2288 & 16.6 & 20.5 \\
\hline & 1433 & 0.021 & 0.005 & 2572 & 43.4 & 107.3 \\
\hline & 1434 & 0.045 & 0.010 & 2221 & 26.3 & 298.2 \\
\hline & 1435 & 0.009 & 0.002 & 2136 & 22.4 & 12.1 \\
\hline & 1436 & 0.005 & 0.001 & 2286 & 35.0 & 280.3 \\
\hline & 1437 & 0.010 & 0.002 & 2023 & 38.3 & 300.9 \\
\hline & 1438 & 0.047 & 0.010 & 2256 & 30.8 & 316.6 \\
\hline & 1439 & 0.009 & 0.002 & 2597 & 46.8 & 168.0 \\
\hline & 1440 & 0.008 & 0.002 & 2001 & 41.0 & 325.1 \\
\hline & 1441 & 0.007 & 0.002 & 2434 & 36.5 & 341.4 \\
\hline & 1442 & 0.038 & 0.016 & 2481 & 34.9 & 59.6 \\
\hline & 1446 & 0.007 & 0.002 & 2289 & 26.6 & 227.5 \\
\hline & 1450 & 0.005 & 0.001 & 2223 & 21.1 & 133.5 \\
\hline & 1451 & 0.035 & 0.008 & 2487 & 53.9 & 7.7 \\
\hline & 1452 & 0.012 & 0.003 & 2321 & 33.2 & 125.4 \\
\hline & 1453 & 0.017 & 0.004 & 2454 & 35.1 & 170.8 \\
\hline & 1456 & 0.015 & 0.003 & 2203 & 24.4 & 158.3 \\
\hline & 1460 & 0.065 & 0.014 & 2312 & 13.5 & 113.8 \\
\hline & 1469 & 0.034 & 0.007 & 2209 & 9.4 & 122.9 \\
\hline & 1477 & 0.025 & 0.006 & 2140 & 16.6 & 31.3 \\
\hline & 1478 & 0.032 & 0.007 & 1839 & 48.7 & 350.2 \\
\hline & 1481 & 0.003 & 0.001 & 2059 & 33.9 & 72.3 \\
\hline & 1536 & 0.103 & 0.023 & 2073 & 14.5 & 37.6 \\
\hline & 1542 & 0.057 & 0.013 & 2034 & 49.3 & 26.4 \\
\hline & 1548 & 0.020 & 0.004 & 2417 & 44.8 & 76.4 \\
\hline & 1549 & 0.113 & 0.010 & 2250 & 65.5 & 21.2 \\
\hline & 1550 & 0.023 & 0.005 & 2291 & 39.8 & 65.7 \\
\hline & 1564 & 0.010 & 0.002 & 2112 & 35.7 & 105.4 \\
\hline & 1567 & 0.001 & 0.000 & 1972 & 12.5 & 116.7 \\
\hline & 1568 & 0.972 & 0.088 & 2270 & 28.9 & 73.8 \\
\hline & 1569 & 0.429 & 0.039 & 2084 & 30.5 & 127.1 \\
\hline & 1571 & 0.395 & 0.087 & 2361 & 25.7 & 96.7 \\
\hline & 1572 & 0.001 & 0.000 & 2446 & 21.4 & 10.9 \\
\hline & 1573 & 0.004 & 0.001 & 1944 & 22.3 & 16.4 \\
\hline & 1574 & 0.337 & 0.074 & 2567 & 35.4 & 351.0 \\
\hline
\end{tabular}




\begin{tabular}{rrrrrrr}
\hline Glacier Name & RECNO & $\begin{array}{r}\text { Area } \\
\mathbf{( k m}^{2} \mathbf{)}\end{array}$ & $\begin{array}{r}\text { Uncert } \\
\mathbf{( k m}^{\mathbf{2}}\end{array}$ & $\begin{array}{r}\text { Mean } \\
\text { Elevation }\end{array}$ & Slope & Aspect \\
\hline & 1575 & 0.005 & 0.001 & 2183 & 24.6 & 2.7 \\
& 1576 & 0.021 & 0.005 & 2172 & 2.1 & 359.8 \\
& 1577 & 0.021 & 0.005 & 2191 & 19.5 & 346.3 \\
& 1579 & 0.005 & 0.001 & 2334 & 26.8 & 351.0 \\
& 1580 & 1.381 & 0.124 & 2556 & 32.2 & 5.7 \\
& 1581 & 0.201 & 0.018 & 2219 & 18.4 & 55.8 \\
& 1582 & 0.198 & 0.018 & 2079 & 27.7 & 30.8 \\
& 1584 & 0.021 & 0.005 & 2188 & 26.9 & 164.7 \\
& 1585 & 0.011 & 0.005 & 2258 & 43.4 & 74.5 \\
& 1587 & 0.012 & 0.003 & 2063 & 26.7 & 322.3 \\
& 1588 & 0.008 & 0.002 & 2420 & 9.7 & 358.1 \\
Gperry Glacier & 1589 & 0.044 & 0.010 & 2384 & 14.3 & 3.0 \\
& 1590 & 0.012 & 0.003 & 2719 & 26.8 & 121.8 \\
& 1593 & 0.046 & 0.010 & 2412 & 21.1 & 71.4 \\
& 1594 & 0.013 & 0.001 & 2407 & 42.9 & 59.1 \\
& 1595 & 0.058 & 0.013 & 2107 & 41.1 & 64.2 \\
& 1596 & 0.013 & 0.003 & 2424 & 10.3 & 353.7 \\
& 1598 & 0.017 & 0.004 & 2231 & 44.0 & 328.9 \\
& 1600 & 0.150 & 0.033 & 1947 & 2.9 & 325.1 \\
& 9980 & 0.022 & 0.005 & 2212 & 12.7 & 97.3 \\
& & & & & & \\
\hline
\end{tabular}

1995

\begin{tabular}{rrrrrrr}
\hline Glacier Name & RECNO & $\begin{array}{r}\text { Area } \\
\left(\mathbf{k m}^{2} \mathbf{)}\right.\end{array}$ & $\begin{array}{r}\text { Uncert } \\
\mathbf{( k m}^{\mathbf{2}} \mathbf{)}\end{array}$ & $\begin{array}{r}\text { Mean } \\
\text { Elevation }\end{array}$ & Slope & Aspect \\
\hline 1005 & 0.030 & 0.003 & 1994 & 27.6 & 34.2 \\
1006 & 0.009 & 0.001 & 2096 & 27.5 & 327.1 \\
1008 & 0.012 & 0.001 & 2288 & 53.8 & 1.1 \\
1010 & 0.007 & 0.001 & 2051 & 32.0 & 38.7 \\
1011 & 0.021 & 0.002 & 2214 & 40.7 & 4.5 \\
1012 & 0.114 & 0.011 & 2404 & 30.0 & 37.1 \\
1014 & 0.020 & 0.002 & 2188 & 21.9 & 68.5 \\
1015 & 0.034 & 0.003 & 2459 & 41.3 & 45.7 \\
1021 & 0.020 & 0.002 & 1713 & 19.8 & 49.6 \\
1022 & 0.096 & 0.010 & 2191 & 26.0 & 342.5 \\
1023 & 0.026 & 0.003 & 2173 & 20.9 & 63.7
\end{tabular}




\begin{tabular}{|c|c|c|c|c|c|c|}
\hline Glacier Name & RECNO & $\begin{array}{r}\text { Area } \\
\left(\mathrm{km}^{2}\right)\end{array}$ & $\begin{array}{r}\text { Uncert } \\
\left(\mathbf{k m}^{2}\right)\end{array}$ & $\begin{array}{r}\text { Mean } \\
\text { Elevation }\end{array}$ & Slope & Aspect \\
\hline & 1024 & 0.254 & 0.025 & 2293 & 25.3 & 352.5 \\
\hline & 1027 & 0.067 & 0.007 & 2352 & 42.2 & 342.1 \\
\hline \multirow[t]{8}{*}{ Hudson Glacier } & 1029 & 0.007 & 0.001 & 2142 & 41.3 & 10.7 \\
\hline & 1030 & 0.005 & 0.000 & 2001 & 42.5 & 353.5 \\
\hline & 1033 & 0.045 & 0.004 & 2301 & 46.0 & 1.5 \\
\hline & 1034 & 0.008 & 0.001 & 2084 & 47.1 & 21.4 \\
\hline & 1037 & 0.008 & 0.001 & 2344 & 49.0 & 332.8 \\
\hline & 1038 & 0.109 & 0.011 & 2137 & 45.1 & 64.2 \\
\hline & 1039 & 0.072 & 0.007 & 2367 & 45.7 & 10.3 \\
\hline & 1040 & 0.007 & 0.001 & 2076 & 38.2 & 80.2 \\
\hline \multirow[t]{15}{*}{ Harris Glacier } & 1044 & 0.056 & 0.006 & 1922 & 17.3 & 5.2 \\
\hline & 1045 & 0.007 & 0.001 & 2257 & 29.0 & 48.3 \\
\hline & 1052 & 0.003 & 0.000 & 2101 & 24.4 & 44.1 \\
\hline & 1056 & 0.002 & 0.000 & 2139 & 57.3 & 343.0 \\
\hline & 1057 & 0.017 & 0.002 & 2273 & 11.4 & 22.3 \\
\hline & 1064 & 0.004 & 0.001 & 2518 & 47.3 & 26.9 \\
\hline & 1065 & 0.006 & 0.001 & 2195 & 40.1 & 6.1 \\
\hline & 1068 & 0.063 & 0.006 & 2172 & 32.0 & 336.5 \\
\hline & 1073 & 0.056 & 0.006 & 2548 & 27.5 & 328.5 \\
\hline & 1075 & 0.144 & 0.014 & 2215 & 31.5 & 31.3 \\
\hline & 1076 & 0.004 & 0.000 & 2304 & 49.2 & 14.5 \\
\hline & 1081 & 0.031 & 0.003 & 2378 & 31.2 & 327.1 \\
\hline & 1084 & 0.153 & 0.015 & 2643 & 31.8 & 56.5 \\
\hline & 1086 & 0.051 & 0.005 & 2669 & 35.3 & 97.7 \\
\hline & 1088 & 0.005 & 0.000 & 2120 & 18.3 & 13.4 \\
\hline \multirow[t]{14}{*}{ Thunderbird Glacier } & 1089 & 0.097 & 0.010 & 2288 & 22.1 & 44.4 \\
\hline & 1090 & 0.163 & 0.016 & 2430 & 43.7 & 91.1 \\
\hline & 1091 & 0.025 & 0.003 & 2421 & 38.1 & 86.7 \\
\hline & 1093 & 0.237 & 0.024 & 2411 & 38.5 & 352.6 \\
\hline & 1095 & 0.059 & 0.006 & 2239 & 34.3 & 309.9 \\
\hline & 1096 & 0.009 & 0.001 & 2334 & 23.0 & 327.9 \\
\hline & 1098 & 0.060 & 0.006 & 2053 & 38.8 & 350.0 \\
\hline & 1100 & 0.018 & 0.002 & 1987 & 43.3 & 297.7 \\
\hline & 1101 & 0.016 & 0.002 & 2765 & 38.6 & 152.4 \\
\hline & 1104 & 0.083 & 0.008 & 2875 & 47.8 & 95.6 \\
\hline & 1109 & 0.022 & 0.002 & 2030 & 25.9 & 24.0 \\
\hline & 1112 & 0.191 & 0.008 & 2129 & 42.2 & 343.3 \\
\hline & 1116 & 0.006 & 0.001 & 1980 & 40.1 & 130.7 \\
\hline & 1117 & 0.008 & 0.001 & 2477 & 47.6 & 41.2 \\
\hline
\end{tabular}




\begin{tabular}{|c|c|c|c|c|c|c|}
\hline Glacier Name & RECNO & $\begin{array}{r}\text { Area } \\
\left(\mathrm{km}^{2}\right)\end{array}$ & $\begin{array}{r}\text { Uncert } \\
\left(\mathbf{k m}^{2}\right)\end{array}$ & $\begin{array}{r}\text { Mean } \\
\text { Elevation }\end{array}$ & Slope & Aspect \\
\hline & 1119 & 0.520 & 0.021 & 2518 & 52.2 & 1.7 \\
\hline \multirow[t]{6}{*}{ Baby Glacier } & 1120 & 0.048 & 0.002 & 2067 & 20.5 & 59.9 \\
\hline & 1121 & 0.015 & 0.002 & 2160 & 35.4 & 187.3 \\
\hline & 1122 & 0.022 & 0.002 & 2136 & 26.9 & 159.1 \\
\hline & 1123 & 0.298 & 0.012 & 2374 & 43.1 & 68.6 \\
\hline & 1124 & 0.041 & 0.004 & 2201 & 51.0 & 155.8 \\
\hline & 1125 & 0.040 & 0.004 & 2267 & 35.7 & 135.6 \\
\hline \multicolumn{7}{|l|}{ Weasel Collar } \\
\hline \multirow[t]{4}{*}{ Glacier } & 1126 & 0.013 & 0.001 & 2185 & 8.8 & 15.5 \\
\hline & 1129 & 0.012 & 0.001 & 1790 & 25.1 & 1.8 \\
\hline & 1130 & 0.021 & 0.002 & 2245 & 30.5 & 92.4 \\
\hline & 1131 & 0.016 & 0.002 & 1899 & 32.6 & 354.4 \\
\hline \multirow[t]{11}{*}{ Carter Glaciers } & 1132 & 0.045 & 0.005 & 2359 & 18.9 & 40.3 \\
\hline & 1133 & 0.059 & 0.006 & 2270 & 27.3 & 109.2 \\
\hline & 1134 & 1.172 & 0.117 & 1970 & 26.2 & 342.3 \\
\hline & 1136 & 0.032 & 0.003 & 2664 & 34.6 & 175.4 \\
\hline & 1137 & 0.004 & 0.000 & 2596 & 32.7 & 185.5 \\
\hline & 1139 & 0.048 & 0.005 & 2297 & 37.3 & 105.1 \\
\hline & 1140 & 0.041 & 0.004 & 2512 & 26.6 & 164.6 \\
\hline & 1143 & 0.165 & 0.016 & 2268 & 22.4 & 54.5 \\
\hline & 1148 & 0.430 & 0.043 & 2185 & 20.2 & 18.7 \\
\hline & 1149 & 0.052 & 0.005 & 2198 & 34.2 & 16.6 \\
\hline & 1150 & 0.004 & 0.000 & 2316 & 20.8 & 70.2 \\
\hline \multirow[t]{2}{*}{ Carter Glaciers } & 1151 & 0.061 & 0.006 & 2198 & 17.7 & 94.7 \\
\hline & 1155 & 0.016 & 0.002 & 2345 & 28.8 & 346.1 \\
\hline \multirow[t]{14}{*}{ Old Sun Glacier } & 1156 & 0.004 & 0.000 & 2673 & 16.8 & 97.3 \\
\hline & 1157 & 0.171 & 0.017 & 2242 & 32.8 & 359.1 \\
\hline & 1159 & 0.017 & 0.002 & 2147 & 32.1 & 46.2 \\
\hline & 1160 & 0.004 & 0.000 & 2221 & 30.1 & 102.3 \\
\hline & 1161 & 0.005 & 0.001 & 2427 & 35.5 & 355.7 \\
\hline & 1162 & 0.011 & 0.001 & 2272 & 38.2 & 166.3 \\
\hline & 1163 & 0.017 & 0.002 & 2908 & 43.6 & 12.5 \\
\hline & 1165 & 0.211 & 0.021 & 2290 & 41.4 & 133.5 \\
\hline & 1166 & 0.002 & 0.000 & 1986 & 34.7 & 232.7 \\
\hline & 1167 & 0.002 & 0.000 & 2243 & 31.7 & 52.6 \\
\hline & 1168 & 0.001 & 0.000 & 2217 & 4.4 & 8.9 \\
\hline & 1169 & 0.083 & 0.008 & 2981 & 35.9 & 59.8 \\
\hline & 1170 & 0.015 & 0.001 & 2249 & 14.6 & 74.0 \\
\hline & 1172 & 0.015 & 0.002 & 1738 & 25.4 & 56.9 \\
\hline
\end{tabular}




\begin{tabular}{|c|c|c|c|c|c|c|}
\hline Glacier Name & RECNO & $\begin{array}{r}\text { Area } \\
\left(\mathrm{km}^{2}\right)\end{array}$ & $\begin{array}{r}\text { Uncert } \\
\left(\mathbf{k m}^{2}\right)\end{array}$ & $\begin{array}{r}\text { Mean } \\
\text { Elevation }\end{array}$ & Slope & Aspect \\
\hline & 1174 & 0.002 & 0.000 & 2265 & 9.0 & 41.3 \\
\hline & 1176 & 0.135 & 0.013 & 2333 & 40.3 & 354.9 \\
\hline & 1179 & 0.496 & 0.050 & 2269 & 8.4 & 69.4 \\
\hline & 1180 & 0.008 & 0.000 & 2311 & 16.6 & 116.9 \\
\hline & 1183 & 0.003 & 0.000 & 2214 & 50.1 & 357.7 \\
\hline \multirow[t]{9}{*}{ Chaney Glacier } & 1185 & 0.003 & 0.000 & 2252 & 17.9 & 26.6 \\
\hline & 1186 & 0.003 & 0.000 & 2046 & 35.2 & 25.1 \\
\hline & 1187 & 0.028 & 0.003 & 2176 & 25.8 & 91.0 \\
\hline & 1188 & 0.327 & 0.013 & 2049 & 54.1 & 356.5 \\
\hline & 1189 & 0.016 & 0.002 & 2122 & 42.1 & 316.4 \\
\hline & 1191 & 0.071 & 0.007 & 2178 & 38.2 & 275.1 \\
\hline & 1192 & 0.360 & 0.036 & 2071 & 40.6 & 7.3 \\
\hline & 1193 & 0.560 & 0.022 & 2735 & 47.0 & 126.7 \\
\hline & 1194 & 0.010 & 0.001 & 2103 & 38.8 & 18.3 \\
\hline \multirow[t]{5}{*}{ Ipasha Glacier } & 1195 & 0.021 & 0.006 & 2288 & 20.8 & 26.8 \\
\hline & 1196 & 0.016 & 0.002 & 2038 & 30.3 & 30.0 \\
\hline & 1197 & 0.007 & 0.001 & 2021 & 38.5 & 332.5 \\
\hline & 1199 & 0.024 & 0.002 & 2492 & 29.8 & 297.0 \\
\hline & 1200 & 0.003 & 0.000 & 2111 & 45.9 & 354.7 \\
\hline \multirow[t]{20}{*}{ Two Ocean Glacier } & 1201 & 0.007 & 0.001 & 2585 & 15.1 & 92.1 \\
\hline & 1203 & 0.008 & 0.001 & 2197 & 38.6 & 142.0 \\
\hline & 1204 & 0.115 & 0.011 & 2684 & 43.3 & 103.1 \\
\hline & 1205 & 0.059 & 0.006 & 2403 & 36.0 & 308.4 \\
\hline & 1206 & 0.016 & 0.002 & 1983 & 21.7 & 131.8 \\
\hline & 1207 & 0.017 & 0.005 & 2300 & 12.5 & 40.4 \\
\hline & 1211 & 0.007 & 0.001 & 2644 & 34.8 & 143.1 \\
\hline & 1213 & 0.029 & 0.003 & 2405 & 20.1 & 55.8 \\
\hline & 1214 & 0.347 & 0.035 & 2485 & 17.5 & 206.6 \\
\hline & 1216 & 0.013 & 0.001 & 2644 & 31.0 & 125.4 \\
\hline & 1219 & 0.124 & 0.012 & 2475 & 18.6 & 4.8 \\
\hline & 1221 & 0.034 & 0.010 & 2431 & 26.9 & 86.3 \\
\hline & 1222 & 0.042 & 0.004 & 2502 & 22.7 & 186.4 \\
\hline & 1227 & 0.016 & 0.002 & 1785 & 31.5 & 74.5 \\
\hline & 1228 & 0.011 & 0.003 & 1971 & 44.0 & 6.8 \\
\hline & 1230 & 0.026 & 0.007 & 2214 & 26.7 & 61.6 \\
\hline & 1232 & 0.109 & 0.004 & 2059 & 15.5 & 93.0 \\
\hline & 1235 & 0.013 & 0.001 & 1763 & 37.2 & 351.4 \\
\hline & 1236 & 0.009 & 0.001 & 2269 & 30.2 & 142.9 \\
\hline & 1237 & 0.032 & 0.003 & 2284 & 30.1 & 30.0 \\
\hline
\end{tabular}




\begin{tabular}{|c|c|c|c|c|c|c|}
\hline Glacier Name & RECNO & $\begin{array}{r}\text { Area } \\
\left(\mathrm{km}^{2}\right)\end{array}$ & $\begin{array}{r}\text { Uncert } \\
\left(\mathbf{k m}^{2}\right)\end{array}$ & $\begin{array}{r}\text { Mean } \\
\text { Elevation }\end{array}$ & Slope & Aspect \\
\hline & 1240 & 0.062 & 0.006 & 1878 & 9.7 & 78.0 \\
\hline & 1243 & 0.064 & 0.006 & 2090 & 44.6 & 110.3 \\
\hline & 1244 & 0.008 & 0.001 & 1881 & 26.7 & 318.5 \\
\hline & 1246 & 0.052 & 0.005 & 2035 & 38.3 & 62.7 \\
\hline & 1247 & 0.013 & 0.001 & 2132 & 15.3 & 57.2 \\
\hline & 1248 & 0.024 & 0.002 & 2178 & 14.4 & 46.9 \\
\hline & 1249 & 0.030 & 0.003 & 2084 & 31.9 & 40.3 \\
\hline & 1250 & 0.035 & 0.003 & 2255 & 37.0 & 99.6 \\
\hline & 1251 & 0.226 & 0.009 & 2070 & 6.7 & 67.6 \\
\hline & 1252 & 0.011 & 0.001 & 2068 & 6.9 & 60.9 \\
\hline & 1253 & 0.066 & 0.007 & 2179 & 27.7 & 32.2 \\
\hline & 1263 & 0.217 & 0.009 & 2304 & 37.4 & 65.8 \\
\hline & 1268 & 0.740 & 0.030 & 2097 & 23.3 & 45.6 \\
\hline & 1274 & 0.019 & 0.002 & 2390 & 46.1 & 349.7 \\
\hline & 1276 & 0.024 & 0.002 & 2172 & 39.7 & 84.2 \\
\hline & 1278 & 0.053 & 0.005 & 2635 & 41.1 & 65.6 \\
\hline & 1279 & 0.013 & 0.001 & 2257 & 37.3 & 103.4 \\
\hline \multirow[t]{22}{*}{ Gem Glacier } & 1283 & 0.092 & 0.009 & 2511 & 38.6 & 36.0 \\
\hline & 1288 & 0.254 & 0.025 & 1730 & 25.6 & 92.8 \\
\hline & 1292 & 0.021 & 0.002 & 2144 & 26.0 & 98.4 \\
\hline & 1293 & 0.020 & 0.002 & 2252 & 38.9 & 356.7 \\
\hline & 1294 & 0.004 & 0.000 & 2117 & 49.4 & 30.1 \\
\hline & 1297 & 0.011 & 0.001 & 2162 & 42.2 & 7.3 \\
\hline & 1299 & 0.017 & 0.002 & 2270 & 48.6 & 4.6 \\
\hline & 1302 & 0.018 & 0.002 & 2325 & 35.6 & 97.1 \\
\hline & 1305 & 0.032 & 0.003 & 1974 & 20.4 & 27.3 \\
\hline & 1308 & 0.014 & 0.001 & 2118 & 24.6 & 35.0 \\
\hline & 1311 & 0.008 & 0.001 & 2222 & 16.8 & 144.9 \\
\hline & 1313 & 0.275 & 0.011 & 2323 & 30.9 & 117.4 \\
\hline & 1317 & 0.021 & 0.002 & 2207 & 35.7 & 356.3 \\
\hline & 1319 & 0.429 & 0.043 & 2315 & 27.5 & 10.4 \\
\hline & 1322 & 0.027 & 0.003 & 2340 & 24.4 & 151.5 \\
\hline & 1341 & 0.003 & 0.001 & 2123 & 26.7 & 49.5 \\
\hline & 1342 & 0.078 & 0.008 & 1941 & 31.2 & 105.0 \\
\hline & 1343 & 0.011 & 0.001 & 2240 & 26.9 & 113.0 \\
\hline & 1347 & 0.006 & 0.001 & 2357 & 34.2 & 358.4 \\
\hline & 1349 & 0.006 & 0.001 & 2062 & 48.3 & 359.1 \\
\hline & 1350 & 0.014 & 0.001 & 1769 & 38.9 & 52.7 \\
\hline & 1353 & 0.004 & 0.000 & 2275 & 25.7 & 76.2 \\
\hline
\end{tabular}




\begin{tabular}{|c|c|c|c|c|c|c|}
\hline Glacier Name & RECNO & $\begin{array}{r}\text { Area } \\
\left(\mathrm{km}^{2}\right)\end{array}$ & $\begin{array}{r}\text { Uncert } \\
\left(\mathbf{k m}^{2}\right)\end{array}$ & $\begin{array}{r}\text { Mean } \\
\text { Elevation }\end{array}$ & Slope & Aspect \\
\hline & 1356 & 0.015 & 0.001 & 2385 & 12.0 & 6.7 \\
\hline & 1357 & 0.008 & 0.001 & 2399 & 40.5 & 134.3 \\
\hline & 1361 & 0.014 & 0.001 & 2076 & 34.5 & 38.5 \\
\hline & 1370 & 0.003 & 0.000 & 2210 & 36.8 & 4.0 \\
\hline & 1372 & 0.001 & 0.000 & 2293 & 19.4 & 357.8 \\
\hline & 1383 & 0.017 & 0.002 & 2550 & 44.0 & 323.6 \\
\hline & 1385 & 0.018 & 0.002 & 2053 & 31.4 & 41.9 \\
\hline & 1386 & 0.011 & 0.003 & 2373 & 25.8 & 65.4 \\
\hline & 1387 & 0.008 & 0.001 & 2353 & 33.1 & 88.1 \\
\hline & 1389 & 0.019 & 0.002 & 2166 & 29.3 & 109.9 \\
\hline & 1391 & 0.004 & 0.000 & 2354 & 38.6 & 23.0 \\
\hline & 1394 & 0.017 & 0.002 & 2173 & 29.1 & 111.3 \\
\hline & 1406 & 0.374 & 0.037 & 2190 & 26.8 & 61.5 \\
\hline & 1410 & 0.501 & 0.050 & 2001 & 24.2 & 78.1 \\
\hline \multirow[t]{3}{*}{ Jackson Glacier } & 1414 & 0.167 & 0.048 & 2180 & 22.9 & 32.9 \\
\hline & 1417 & 1.689 & 0.068 & 2100 & 22.5 & 81.8 \\
\hline & 1421 & 0.002 & 0.000 & 2274 & 29.7 & 316.4 \\
\hline \multirow[t]{15}{*}{ Logan Glacier } & 1423 & 0.003 & 0.000 & 2213 & 23.4 & 38.3 \\
\hline & 1424 & 0.015 & 0.002 & 2498 & 30.4 & 323.3 \\
\hline & 1429 & 0.013 & 0.001 & 2771 & 30.8 & 85.6 \\
\hline & 1431 & 0.470 & 0.047 & 2418 & 36.6 & 286.4 \\
\hline & 1432 & 0.069 & 0.003 & 2789 & 45.5 & 165.1 \\
\hline & 1433 & 0.031 & 0.003 & 2572 & 43.4 & 107.3 \\
\hline & 1434 & 0.045 & 0.004 & 2221 & 26.3 & 298.2 \\
\hline & 1444 & 0.160 & 0.016 & 2502 & 40.6 & 15.0 \\
\hline & 1445 & 0.007 & 0.001 & 2336 & 35.5 & 319.3 \\
\hline & 1448 & 0.990 & 0.040 & 2429 & 38.5 & 312.8 \\
\hline & 1449 & 0.008 & 0.001 & 2523 & 32.3 & 350.1 \\
\hline & 1454 & 0.008 & 0.001 & 2245 & 30.5 & 120.0 \\
\hline & 1458 & 0.040 & 0.004 & 2280 & 25.8 & 133.4 \\
\hline & 1459 & 0.093 & 0.009 & 2513 & 34.0 & 92.9 \\
\hline & 1461 & 0.003 & 0.001 & 2267 & 22.2 & 135.5 \\
\hline \multirow[t]{7}{*}{ Pumpelly Glacier } & 1466 & 0.036 & 0.004 & 2527 & 24.8 & 78.2 \\
\hline & 1468 & 0.020 & 0.002 & 2165 & 23.6 & 64.2 \\
\hline & 1471 & 0.010 & 0.001 & 2663 & 28.2 & 346.2 \\
\hline & 1472 & 0.052 & 0.005 & 2527 & 29.6 & 333.7 \\
\hline & 1473 & 0.014 & 0.001 & 2157 & 24.4 & 128.2 \\
\hline & 1474 & 0.026 & 0.003 & 2168 & 6.1 & 95.7 \\
\hline & 1479 & 0.004 & 0.000 & 2112 & 37.3 & 287.9 \\
\hline
\end{tabular}




\begin{tabular}{|c|c|c|c|c|c|c|}
\hline Glacier Name & RECNO & $\begin{array}{l}\text { Area } \\
\left(\mathrm{km}^{2}\right)\end{array}$ & $\begin{array}{r}\text { Uncert } \\
\left(\mathrm{km}^{2}\right)\end{array}$ & $\begin{array}{r}\text { Mean } \\
\text { Elevation }\end{array}$ & Slope & Aspect \\
\hline & 1480 & 0.005 & 0.001 & 2181 & 30.4 & 358.8 \\
\hline & 1482 & 0.004 & 0.000 & 2031 & 17.1 & 14.6 \\
\hline & 1483 & 0.010 & 0.001 & 2330 & 44.1 & 354.9 \\
\hline & 1484 & 0.013 & 0.001 & 2248 & 15.0 & 64.5 \\
\hline & 1485 & 0.017 & 0.002 & 2813 & 42.2 & 103.4 \\
\hline & 1486 & 0.011 & 0.001 & 2386 & 38.2 & 332.9 \\
\hline & 1487 & 0.012 & 0.001 & 2481 & 34.8 & 175.3 \\
\hline & 1567 & 0.001 & 0.000 & 1972 & 12.5 & 116.7 \\
\hline & 1568 & 0.956 & 0.038 & 2270 & 28.9 & 73.8 \\
\hline & 1569 & 0.418 & 0.042 & 2084 & 30.5 & 127.1 \\
\hline & 1572 & 0.001 & 0.000 & 2446 & 21.4 & 10.9 \\
\hline & 1573 & 0.004 & 0.000 & 1944 & 22.3 & 16.4 \\
\hline & 1575 & 0.005 & 0.000 & 2183 & 24.6 & 2.7 \\
\hline & 1576 & 0.023 & 0.002 & 2172 & 2.1 & 359.8 \\
\hline & 1577 & 0.015 & 0.004 & 2191 & 19.5 & 346.3 \\
\hline & 1578 & 0.001 & 0.000 & 2089 & 33.1 & 9.0 \\
\hline & 1579 & 0.002 & 0.000 & 2334 & 26.8 & 351.0 \\
\hline & 1584 & 0.023 & 0.002 & 2188 & 26.9 & 164.7 \\
\hline & 1585 & 0.013 & 0.001 & 2258 & 43.4 & 74.5 \\
\hline & 1587 & 0.012 & 0.001 & 2063 & 26.7 & 322.3 \\
\hline & 1590 & 0.011 & 0.001 & 2719 & 26.8 & 121.8 \\
\hline \multirow[t]{5}{*}{ Grant Glacier } & 1593 & 0.047 & 0.005 & 2412 & 21.1 & 71.4 \\
\hline & 1594 & 0.013 & 0.001 & 2407 & 42.9 & 59.1 \\
\hline & 1595 & 0.068 & 0.007 & 2107 & 41.1 & 64.2 \\
\hline & 1598 & 0.015 & 0.001 & 2231 & 44.0 & 328.9 \\
\hline & 1600 & 0.129 & 0.013 & 1947 & 2.9 & 325.1 \\
\hline
\end{tabular}

\section{8}

\begin{tabular}{rrrrrrr}
\hline Glacier Name & RECNO & $\begin{array}{r}\text { Area } \\
\left(\mathbf{k m}^{\mathbf{2}}\right)\end{array}$ & $\begin{array}{r}\text { Uncert } \\
\left(\mathbf{k m}^{2}\right)\end{array}$ & $\begin{array}{r}\text { Mean } \\
\text { Elevation }\end{array}$ & Slope & Aspect \\
\hline & 1011 & 0.016 & 0.001 & 2214 & 40.7 & 4.5 \\
Herbst Glacier & 1012 & 0.017 & 0.001 & 2404 & 30.0 & 37.1 \\
& 1013 & 0.051 & 0.002 & 2245 & 32.2 & 59.4 \\
& 1015 & 0.009 & 0.001 & 2459 & 41.3 & 45.7 \\
& 1016 & 0.003 & 0.000 & 2559 & 38.0 & 41.9
\end{tabular}




\begin{tabular}{|c|c|c|c|c|c|c|}
\hline Glacier Name & RECNO & $\begin{array}{r}\text { Area } \\
\left(\mathrm{km}^{2}\right)\end{array}$ & $\begin{array}{r}\text { Uncert } \\
\left(\mathbf{k m}^{2}\right) \\
\end{array}$ & $\begin{array}{r}\text { Mean } \\
\text { Elevation }\end{array}$ & Slope & Aspect \\
\hline \multirow[t]{2}{*}{ Hudson Glacier } & 1029 & 0.046 & 0.002 & 2142 & 41.3 & 10.7 \\
\hline & 1036 & 0.005 & 0.000 & 2346 & 47.8 & 12.9 \\
\hline Boulder Glacier & 1041 & 0.060 & 0.002 & 2369 & 25.7 & 15.4 \\
\hline \multirow[t]{2}{*}{ Harris Glacier } & 1044 & 0.040 & 0.003 & 1922 & 17.3 & 5.2 \\
\hline & 1052 & 0.060 & 0.005 & 2101 & 24.4 & 44.1 \\
\hline \multirow[t]{6}{*}{ Agassiz Glacier } & 1055 & 1.174 & 0.047 & 2376 & 13.6 & 66.0 \\
\hline & 1061 & 0.001 & 0.000 & 2196 & 26.4 & 68.2 \\
\hline & 1067 & 0.005 & 0.000 & 2364 & 8.1 & 318.4 \\
\hline & 1068 & 0.065 & 0.003 & 2172 & 32.0 & 336.5 \\
\hline & 1069 & 0.015 & 0.001 & 2117 & 40.1 & 338.7 \\
\hline & 1071 & 0.042 & 0.003 & 2109 & 24.0 & 43.3 \\
\hline \multirow[t]{2}{*}{ Kintla Glacier } & 1072 & 1.014 & 0.041 & 2579 & 17.1 & 13.6 \\
\hline & 1073 & 0.165 & 0.007 & 2548 & 27.5 & 328.5 \\
\hline \multirow[t]{10}{*}{ Miche Waburn } & 1074 & 0.102 & 0.008 & 2208 & 31.0 & 12.1 \\
\hline & 1075 & 0.003 & 0.000 & 2215 & 31.5 & 31.3 \\
\hline & 1077 & 0.021 & 0.002 & 2259 & 39.9 & 321.0 \\
\hline & 1078 & 0.001 & 0.000 & 2415 & 9.2 & 0.5 \\
\hline & 1079 & 0.013 & 0.001 & 2365 & 34.1 & 22.4 \\
\hline & 1081 & 0.061 & 0.005 & 2378 & 31.2 & 327.1 \\
\hline & 1084 & 0.158 & 0.006 & 2643 & 31.8 & 56.5 \\
\hline & 1085 & 0.021 & 0.002 & 2207 & 28.0 & 62.5 \\
\hline & 1086 & 0.017 & 0.001 & 2669 & 35.3 & 97.7 \\
\hline & 1088 & 0.111 & 0.009 & 2120 & 18.3 & 13.4 \\
\hline \multirow[t]{4}{*}{ Thunderbird Glacier } & 1089 & 0.132 & 0.005 & 2288 & 22.1 & 44.4 \\
\hline & 1090 & 0.001 & 0.000 & 2430 & 43.7 & 91.1 \\
\hline & 1091 & 0.066 & 0.005 & 2421 & 38.1 & 86.7 \\
\hline & 1093 & 0.028 & 0.002 & 2411 & 38.5 & 352.6 \\
\hline \multirow[t]{8}{*}{ Dixon Glacier } & 1094 & 0.184 & 0.007 & 2263 & 24.3 & 20.2 \\
\hline & 1096 & 0.032 & 0.003 & 2334 & 23.0 & 327.9 \\
\hline & 1101 & 0.003 & 0.000 & 2765 & 38.6 & 152.4 \\
\hline & 1104 & 0.011 & 0.000 & 2875 & 47.8 & 95.6 \\
\hline & 1105 & 0.013 & 0.001 & 2572 & 37.8 & 96.2 \\
\hline & 1108 & 0.055 & 0.004 & 2133 & 32.0 & 128.1 \\
\hline & 1114 & 0.008 & 0.000 & 2292 & 41.1 & 108.1 \\
\hline & 1115 & 0.013 & 0.001 & 2073 & 33.9 & 106.7 \\
\hline Whitecrow Glacier & 1118 & 0.154 & 0.006 & 2004 & 19.9 & 93.1 \\
\hline Baby Glacier & 1120 & 0.080 & 0.006 & 2067 & 20.5 & 59.9 \\
\hline \multirow[t]{2}{*}{ Weasel Collar } & 1126 & 0.525 & 0.021 & 2185 & 8.8 & 15.5 \\
\hline & 1128 & 0.043 & 0.002 & 2590 & 37.7 & 42.5 \\
\hline
\end{tabular}




\begin{tabular}{|c|c|c|c|c|c|c|}
\hline Glacier Name & RECNO & $\begin{array}{r}\text { Area } \\
\left(\mathrm{km}^{2}\right)\end{array}$ & $\begin{array}{r}\text { Uncert } \\
\left(\mathbf{k m}^{2}\right)\end{array}$ & $\begin{array}{r}\text { Mean } \\
\text { Elevation }\end{array}$ & Slope & Aspect \\
\hline \multirow[t]{5}{*}{ Carter Glaciers } & 1132 & 0.270 & 0.022 & 2359 & 18.9 & 40.3 \\
\hline & 1135 & 0.009 & 0.001 & 2428 & 28.7 & 64.4 \\
\hline & 1137 & 0.004 & 0.000 & 2596 & 32.7 & 185.5 \\
\hline & 1138 & 0.008 & 0.001 & 2614 & 27.4 & 331.5 \\
\hline & 1140 & 0.032 & 0.003 & 2512 & 26.6 & 164.6 \\
\hline \multirow[t]{4}{*}{ Rainbow Glacier } & 1141 & 1.171 & 0.047 & 2495 & 11.2 & 96.4 \\
\hline & 1143 & 0.020 & 0.002 & 2268 & 22.4 & 54.5 \\
\hline & 1146 & 0.020 & 0.002 & 2479 & 37.2 & 38.5 \\
\hline & 1147 & 0.001 & 0.000 & 2362 & 43.9 & 32.8 \\
\hline \multirow[t]{2}{*}{ Old Sun Glacier } & 1156 & 0.378 & 0.015 & 2673 & 16.8 & 97.3 \\
\hline & 1160 & 0.027 & 0.002 & 2221 & 30.1 & 102.3 \\
\hline \multirow[t]{4}{*}{ Shepard Glacier } & 1164 & 0.113 & 0.009 & 2330 & 33.4 & 68.5 \\
\hline & 1169 & 0.001 & 0.000 & 2981 & 35.9 & 59.8 \\
\hline & 1178 & 0.002 & 0.000 & 2314 & 14.8 & 34.0 \\
\hline & 1181 & 0.000 & 0.000 & 2223 & 29.4 & 110.0 \\
\hline \multirow[t]{2}{*}{ Chaney Glacier } & 1185 & 0.428 & 0.017 & 2252 & 17.9 & 26.6 \\
\hline & 1186 & 0.002 & 0.000 & 2046 & 35.2 & 25.1 \\
\hline \multirow[t]{3}{*}{ Ipasha Glacier } & 1195 & 0.245 & 0.010 & 2288 & 20.8 & 26.8 \\
\hline & 1197 & 0.001 & 0.000 & 2021 & 38.5 & 332.5 \\
\hline & 1200 & 0.001 & 0.000 & 2111 & 45.9 & 354.7 \\
\hline Two Ocean Glacier & 1201 & 0.290 & 0.012 & 2585 & 15.1 & 92.1 \\
\hline \multirow[t]{9}{*}{ Ahern Glacier } & 1202 & 0.517 & 0.021 & 2489 & 12.0 & 85.2 \\
\hline & 1204 & 0.001 & 0.000 & 2684 & 43.3 & 103.1 \\
\hline & 1208 & 0.003 & 0.000 & 2410 & 31.7 & 306.8 \\
\hline & 1209 & 0.017 & 0.001 & 2528 & 19.5 & 63.1 \\
\hline & 1210 & 0.006 & 0.000 & 2666 & 35.0 & 72.8 \\
\hline & 1214 & 0.002 & 0.000 & 2485 & 17.5 & 206.6 \\
\hline & 1216 & 0.005 & 0.000 & 2644 & 31.0 & 125.4 \\
\hline & 1218 & 0.001 & 0.000 & 2526 & 25.7 & 195.5 \\
\hline & 1222 & 0.011 & 0.001 & 2502 & 22.7 & 186.4 \\
\hline \multirow[t]{7}{*}{ Vulture Glacier } & 1224 & 0.352 & 0.014 & 2565 & 32.0 & 81.9 \\
\hline & 1229 & 0.029 & 0.001 & 2703 & 33.3 & 142.8 \\
\hline & 1230 & 0.005 & 0.000 & 2214 & 26.7 & 61.6 \\
\hline & 1251 & 0.001 & 0.000 & 2070 & 6.7 & 67.6 \\
\hline & 1253 & 0.051 & 0.002 & 2179 & 27.7 & 32.2 \\
\hline & 1254 & 0.030 & 0.001 & 2115 & 43.9 & 14.5 \\
\hline & 1255 & 0.009 & 0.001 & 2385 & 48.4 & 51.5 \\
\hline \multirow[t]{2}{*}{ Swiftcurrent Glacier } & 1259 & 0.189 & 0.008 & 2231 & 40.6 & 28.1 \\
\hline & 1260 & 0.005 & 0.000 & 2243 & 17.2 & 6.8 \\
\hline
\end{tabular}




\begin{tabular}{|c|c|c|c|c|c|c|}
\hline Glacier Name & RECNO & $\begin{array}{r}\text { Area } \\
\left(\mathrm{km}^{2}\right)\end{array}$ & $\begin{array}{r}\text { Uncert } \\
\left(\mathbf{k m}^{2}\right)\end{array}$ & $\begin{array}{r}\text { Mean } \\
\text { Elevation }\end{array}$ & Slope & Aspect \\
\hline & 1261 & 0.046 & 0.002 & 2219 & 34.2 & 334.3 \\
\hline Salamander Glacier & 1271 & 0.187 & 0.007 & 2196 & 16.6 & 107.0 \\
\hline Grinnell Glacier & 1277 & 0.716 & 0.029 & 2025 & 7.4 & 14.2 \\
\hline \multirow[t]{5}{*}{ Gem Glacier } & 1283 & 0.023 & 0.001 & 2511 & 38.6 & 36.0 \\
\hline & 1284 & 0.059 & 0.002 & 2017 & 21.0 & 50.4 \\
\hline & 1287 & 0.020 & 0.002 & 2646 & 42.4 & 356.7 \\
\hline & 1288 & 0.026 & 0.002 & 1730 & 25.6 & 92.8 \\
\hline & 1291 & 0.075 & 0.003 & 2166 & 16.9 & 94.8 \\
\hline Siyeh Glacier & 1296 & 0.198 & 0.005 & 2106 & 18.5 & 17.0 \\
\hline \multirow[t]{2}{*}{ Piegan Glacier } & 1323 & 0.274 & 0.011 & 2512 & 16.4 & 54.3 \\
\hline & 1325 & 0.017 & 0.001 & 2471 & 45.2 & 128.1 \\
\hline \multirow[t]{4}{*}{ Sexton Glacier } & 1329 & 0.306 & 0.012 & 2225 & 24.2 & 76.3 \\
\hline & 1372 & 0.001 & 0.000 & 2293 & 19.4 & 357.8 \\
\hline & 1381 & 0.001 & 0.000 & 2494 & 36.6 & 3.0 \\
\hline & 1383 & 0.000 & 0.000 & 2550 & 44.0 & 323.6 \\
\hline \multirow[t]{4}{*}{ Jackson Glacier } & 1414 & 0.964 & 0.039 & 2180 & 22.9 & 32.9 \\
\hline & 1417 & 0.001 & 0.000 & 2100 & 22.5 & 81.8 \\
\hline & 1420 & 0.003 & 0.000 & 2075 & 15.9 & 76.1 \\
\hline & 1421 & 0.234 & 0.019 & 2274 & 29.7 & 316.4 \\
\hline \multirow[t]{3}{*}{ Logan Glacier } & 1423 & 0.349 & 0.014 & 2213 & 23.4 & 38.3 \\
\hline & 1428 & 0.016 & 0.001 & 2658 & 38.6 & 87.6 \\
\hline & 1429 & 0.030 & 0.005 & 2771 & 30.8 & 85.6 \\
\hline \multirow[t]{8}{*}{ Blackfoot Glacier } & 1430 & 1.548 & 0.062 & 2288 & 16.6 & 20.5 \\
\hline & 1432 & 0.049 & 0.002 & 2789 & 45.5 & 165.1 \\
\hline & 1433 & 0.007 & 0.001 & 2572 & 43.4 & 107.3 \\
\hline & 1439 & 0.003 & 0.000 & 2597 & 46.8 & 168.0 \\
\hline & 1441 & 0.117 & 0.005 & 2434 & 36.5 & 341.4 \\
\hline & 1442 & 0.007 & 0.001 & 2481 & 34.9 & 59.6 \\
\hline & 1443 & 0.335 & 0.027 & 2395 & 21.5 & 117.7 \\
\hline & 1444 & 0.025 & 0.001 & 2502 & 40.6 & 15.0 \\
\hline \multirow[t]{9}{*}{ Red Eagle Glacier } & 1447 & 0.094 & 0.008 & 2156 & 22.1 & 32.2 \\
\hline & 1448 & 0.054 & 0.002 & 2429 & 38.5 & 312.8 \\
\hline & 1449 & 0.009 & 0.001 & 2523 & 32.3 & 350.1 \\
\hline & 1450 & 0.022 & 0.002 & 2223 & 21.1 & 133.5 \\
\hline & 1452 & 0.002 & 0.000 & 2321 & 33.2 & 125.4 \\
\hline & 1453 & 0.006 & 0.001 & 2454 & 35.1 & 170.8 \\
\hline & 1454 & 0.001 & 0.000 & 2245 & 30.5 & 120.0 \\
\hline & 1455 & 0.029 & 0.002 & 2373 & 20.8 & 148.0 \\
\hline & 1456 & 0.004 & 0.000 & 2203 & 24.4 & 158.3 \\
\hline
\end{tabular}




\begin{tabular}{|c|c|c|c|c|c|c|}
\hline Glacier Name & RECNO & $\begin{array}{r}\text { Area } \\
\left(\mathrm{km}^{2}\right)\end{array}$ & $\begin{array}{r}\text { Uncert } \\
\left(\mathbf{k m}^{2}\right)\end{array}$ & $\begin{array}{r}\text { Mean } \\
\text { Elevation }\end{array}$ & Slope & Aspect \\
\hline & 1457 & 0.120 & 0.005 & 2418 & 9.6 & 70.9 \\
\hline & 1458 & 0.004 & 0.000 & 2280 & 25.8 & 133.4 \\
\hline & 1459 & 0.003 & 0.000 & 2513 & 34.0 & 92.9 \\
\hline & 1461 & 0.004 & 0.000 & 2267 & 22.2 & 135.5 \\
\hline & 1462 & 0.010 & 0.002 & 2494 & 15.7 & 226.9 \\
\hline & 1464 & 0.002 & 0.000 & 2157 & 24.1 & 148.3 \\
\hline & 1465 & 0.007 & 0.001 & 2459 & 14.4 & 218.1 \\
\hline \multirow[t]{13}{*}{ Pumpelly Glacier } & 1466 & 0.881 & 0.035 & 2527 & 24.8 & 78.2 \\
\hline & 1468 & 0.014 & 0.001 & 2165 & 23.6 & 64.2 \\
\hline & 1470 & 0.002 & 0.000 & 2055 & 18.0 & 163.3 \\
\hline & 1471 & 0.033 & 0.003 & 2663 & 28.2 & 346.2 \\
\hline & 1472 & 0.068 & 0.005 & 2527 & 29.6 & 333.7 \\
\hline & 1473 & 0.043 & 0.003 & 2157 & 24.4 & 128.2 \\
\hline & 1484 & 0.022 & 0.002 & 2248 & 15.0 & 64.5 \\
\hline & 1485 & 0.012 & 0.001 & 2813 & 42.2 & 103.4 \\
\hline & 1487 & 0.019 & 0.001 & 2481 & 34.8 & 175.3 \\
\hline & 1489 & 0.003 & 0.000 & 2758 & 40.4 & 142.3 \\
\hline & 1490 & 0.008 & 0.001 & 2349 & 33.7 & 48.6 \\
\hline & 1492 & 0.016 & 0.001 & 1905 & 13.8 & 67.4 \\
\hline & 1496 & 0.006 & 0.000 & 1852 & 14.1 & 57.1 \\
\hline \multirow[t]{2}{*}{ Lupfer Glacier } & 1555 & 0.069 & 0.003 & 1868 & 30.6 & 94.9 \\
\hline & 1588 & 0.268 & 0.011 & 2420 & 9.7 & 358.1 \\
\hline Sperry Glacier & 1589 & 0.934 & 0.037 & 2384 & 14.3 & 3.0 \\
\hline \multirow[t]{3}{*}{ Grant Glacier } & 1593 & 0.310 & 0.012 & 2412 & 21.1 & 71.4 \\
\hline & 1594 & 0.001 & 0.000 & 2407 & 42.9 & 59.1 \\
\hline & 1596 & 0.001 & 0.000 & 2424 & 10.3 & 353.7 \\
\hline \multirow[t]{3}{*}{ Harrison Glacier } & 1601 & 1.382 & 0.055 & 2492 & 9.5 & 94.7 \\
\hline & 1602 & 0.181 & 0.007 & 2203 & 15.7 & 92.9 \\
\hline & 9980 & 0.190 & 0.008 & 2212 & 12.7 & 97.3 \\
\hline
\end{tabular}

2003

\begin{tabular}{rrrrrrr}
\hline Glacier Name & RECNO & $\begin{array}{r}\text { Area } \\
\left.\mathbf{( k m}^{2}\right)\end{array}$ & $\begin{array}{r}\text { Uncert } \\
\left.\mathbf{( k m}^{2}\right)\end{array}$ & $\begin{array}{r}\text { Mean } \\
\text { Elevation }\end{array}$ & Slope & Aspect \\
\hline & 1004 & 0.023 & 0.003 & 2375 & 12.9 & 103.2 \\
& 1005 & 0.043 & 0.006 & 1994 & 27.6 & 34.2
\end{tabular}




\begin{tabular}{|c|c|c|c|c|c|c|}
\hline Glacier Name & RECNO & $\begin{array}{r}\text { Area } \\
\left(\mathrm{km}^{2}\right)\end{array}$ & $\begin{array}{r}\text { Uncert } \\
\left(\mathbf{k m}^{2}\right)\end{array}$ & $\begin{array}{r}\text { Mean } \\
\text { Elevation }\end{array}$ & Slope & Aspect \\
\hline & 1006 & 0.006 & 0.002 & 2096 & 27.5 & 327.1 \\
\hline & 1011 & 0.008 & 0.002 & 2214 & 40.7 & 4.5 \\
\hline & 1012 & 0.017 & 0.002 & 2404 & 30.0 & 37.1 \\
\hline \multirow[t]{9}{*}{ Herbst Glacier } & 1013 & 0.042 & 0.003 & 2245 & 32.2 & 59.4 \\
\hline & 1015 & 0.009 & 0.001 & 2459 & 41.3 & 45.7 \\
\hline & 1016 & 0.009 & 0.001 & 2559 & 38.0 & 41.9 \\
\hline & 1017 & 0.015 & 0.002 & 2311 & 40.9 & 332.2 \\
\hline & 1021 & 0.115 & 0.015 & 1713 & 19.8 & 49.6 \\
\hline & 1024 & 0.057 & 0.017 & 2293 & 25.3 & 352.5 \\
\hline & 1025 & 0.012 & 0.003 & 1647 & 35.2 & 344.2 \\
\hline & 1026 & 0.176 & 0.023 & 2443 & 42.2 & 356.2 \\
\hline & 1027 & 0.018 & 0.002 & 2352 & 42.2 & 342.1 \\
\hline \multirow[t]{6}{*}{ Hudson Glacier } & 1029 & 0.039 & 0.005 & 2142 & 41.3 & 10.7 \\
\hline & 1031 & 0.001 & 0.000 & 2139 & 28.5 & 354.9 \\
\hline & 1033 & 0.004 & 0.001 & 2301 & 46.0 & 1.5 \\
\hline & 1035 & 0.014 & 0.004 & 1943 & 30.4 & 75.3 \\
\hline & 1036 & 0.005 & 0.001 & 2346 & 47.8 & 12.9 \\
\hline & 1038 & 0.003 & 0.001 & 2137 & 45.1 & 64.2 \\
\hline \multirow[t]{2}{*}{ Boulder Glacier } & 1041 & 0.040 & 0.005 & 2369 & 25.7 & 15.4 \\
\hline & 1043 & 0.007 & 0.000 & 2438 & 32.4 & 27.0 \\
\hline \multirow[t]{3}{*}{ Harris Glacier } & 1044 & 0.040 & 0.005 & 1922 & 17.3 & 5.2 \\
\hline & 1052 & 0.013 & 0.004 & 2101 & 24.4 & 44.1 \\
\hline & 1054 & 0.002 & 0.000 & 2085 & 27.8 & 331.3 \\
\hline \multirow[t]{10}{*}{ Agassiz Glacier } & 1055 & 1.008 & 0.060 & 2376 & 13.6 & 66.0 \\
\hline & 1059 & 0.004 & 0.000 & 2084 & 28.2 & 350.3 \\
\hline & 1060 & 0.149 & 0.019 & 2127 & 31.8 & 32.5 \\
\hline & 1065 & 0.001 & 0.000 & 2195 & 40.1 & 6.1 \\
\hline & 1066 & 0.002 & 0.000 & 2246 & 39.8 & 336.6 \\
\hline & 1067 & 0.005 & 0.001 & 2364 & 8.1 & 318.4 \\
\hline & 1068 & 0.060 & 0.018 & 2172 & 32.0 & 336.5 \\
\hline & 1069 & 0.012 & 0.004 & 2117 & 40.1 & 338.7 \\
\hline & 1071 & 0.046 & 0.006 & 2109 & 24.0 & 43.3 \\
\hline & 1073 & 0.153 & 0.020 & 2548 & 27.5 & 328.5 \\
\hline \multirow[t]{6}{*}{ Miche Waburn } & 1074 & 0.114 & 0.007 & 2208 & 31.0 & 12.1 \\
\hline & 1075 & 0.003 & 0.000 & 2215 & 31.5 & 31.3 \\
\hline & 1077 & 0.015 & 0.002 & 2259 & 39.9 & 321.0 \\
\hline & 1079 & 0.018 & 0.002 & 2365 & 34.1 & 22.4 \\
\hline & 1081 & 0.040 & 0.005 & 2378 & 31.2 & 327.1 \\
\hline & 1082 & 0.003 & 0.000 & 2507 & 30.0 & 10.8 \\
\hline
\end{tabular}




\begin{tabular}{|c|c|c|c|c|c|c|}
\hline Glacier Name & RECNO & $\begin{array}{r}\text { Area } \\
\left(\mathrm{km}^{2}\right)\end{array}$ & $\begin{array}{r}\text { Uncert } \\
\left(\mathbf{k m}^{2}\right)\end{array}$ & $\begin{array}{r}\text { Mean } \\
\text { Elevation }\end{array}$ & Slope & Aspect \\
\hline & 1085 & 0.015 & 0.002 & 2207 & 28.0 & 62.5 \\
\hline & 1086 & 0.016 & 0.002 & 2669 & 35.3 & 97.7 \\
\hline & 1088 & 0.074 & 0.010 & 2120 & 18.3 & 13.4 \\
\hline \multirow[t]{4}{*}{ Thunderbird Glacier } & 1089 & 0.125 & 0.007 & 2288 & 22.1 & 44.4 \\
\hline & 1090 & 0.002 & 0.001 & 2430 & 43.7 & 91.1 \\
\hline & 1091 & 0.066 & 0.009 & 2421 & 38.1 & 86.7 \\
\hline & 1093 & 0.028 & 0.004 & 2411 & 38.5 & 352.6 \\
\hline \multirow[t]{12}{*}{ Dixon Glacier } & 1094 & 0.173 & 0.010 & 2263 & 24.3 & 20.2 \\
\hline & 1095 & 0.004 & 0.001 & 2239 & 34.3 & 309.9 \\
\hline & 1096 & 0.024 & 0.003 & 2334 & 23.0 & 327.9 \\
\hline & 1097 & 0.050 & 0.003 & 1890 & 24.5 & 102.9 \\
\hline & 1098 & 0.004 & 0.001 & 2053 & 38.8 & 350.0 \\
\hline & 1099 & 0.008 & 0.001 & 2033 & 33.1 & 278.8 \\
\hline & 1102 & 0.048 & 0.014 & 2022 & 41.4 & 354.2 \\
\hline & 1103 & 0.002 & 0.000 & 1997 & 60.9 & 274.6 \\
\hline & 1105 & 0.014 & 0.002 & 2572 & 37.8 & 96.2 \\
\hline & 1108 & 0.050 & 0.007 & 2133 & 32.0 & 128.1 \\
\hline & 1114 & 0.012 & 0.002 & 2292 & 41.1 & 108.1 \\
\hline & 1115 & 0.014 & 0.002 & 2073 & 33.9 & 106.7 \\
\hline Whitecrow Glacier & 1118 & 0.127 & 0.008 & 2004 & 19.9 & 93.1 \\
\hline \multirow[t]{4}{*}{ Baby Glacier } & 1120 & 0.078 & 0.005 & 2067 & 20.5 & 59.9 \\
\hline & 1122 & 0.002 & 0.000 & 2136 & 26.9 & 159.1 \\
\hline & 1123 & 0.002 & 0.000 & 2374 & 43.1 & 68.6 \\
\hline & 1125 & 0.004 & 0.001 & 2267 & 35.7 & 135.6 \\
\hline \multicolumn{7}{|l|}{ Weasel Collar } \\
\hline \multirow[t]{5}{*}{ Glacier } & 1126 & 0.507 & 0.030 & 2185 & 8.8 & 15.5 \\
\hline & 1128 & 0.048 & 0.003 & 2590 & 37.7 & 42.5 \\
\hline & 1129 & 0.005 & 0.002 & 1790 & 25.1 & 1.8 \\
\hline & 1130 & 0.012 & 0.002 & 2245 & 30.5 & 92.4 \\
\hline & 1131 & 0.037 & 0.005 & 1899 & 32.6 & 354.4 \\
\hline \multirow[t]{6}{*}{ Carter Glaciers } & 1132 & 0.224 & 0.013 & 2359 & 18.9 & 40.3 \\
\hline & 1133 & 0.012 & 0.002 & 2270 & 27.3 & 109.2 \\
\hline & 1135 & 0.012 & 0.002 & 2428 & 28.7 & 64.4 \\
\hline & 1137 & 0.003 & 0.000 & 2596 & 32.7 & 185.5 \\
\hline & 1138 & 0.012 & 0.004 & 2614 & 27.4 & 331.5 \\
\hline & 1140 & 0.017 & 0.002 & 2512 & 26.6 & 164.6 \\
\hline \multirow[t]{3}{*}{ Rainbow Glacier } & 1141 & 1.095 & 0.066 & 2495 & 11.2 & 96.4 \\
\hline & 1143 & 0.012 & 0.002 & 2268 & 22.4 & 54.5 \\
\hline & 1144 & 0.007 & 0.001 & 2238 & 28.1 & 85.7 \\
\hline
\end{tabular}




\begin{tabular}{|c|c|c|c|c|c|c|}
\hline Glacier Name & RECNO & $\begin{array}{r}\text { Area } \\
\left(\mathbf{k m}^{2}\right)\end{array}$ & $\begin{array}{r}\text { Uncert } \\
\left(\mathbf{k m}^{2}\right)\end{array}$ & $\begin{array}{r}\text { Mean } \\
\text { Elevation }\end{array}$ & Slope & Aspect \\
\hline & 1146 & 0.021 & 0.003 & 2479 & 37.2 & 38.5 \\
\hline & 1148 & 0.015 & 0.002 & 2185 & 20.2 & 18.7 \\
\hline Carter Glaciers & 1151 & 0.045 & 0.006 & 2198 & 17.7 & 94.7 \\
\hline \multirow[t]{3}{*}{ Old Sun Glacier } & 1156 & 0.367 & 0.022 & 2673 & 16.8 & 97.3 \\
\hline & 1157 & 0.038 & 0.005 & 2242 & 32.8 & 359.1 \\
\hline & 1160 & 0.010 & 0.001 & 2221 & 30.1 & 102.3 \\
\hline \multirow[t]{7}{*}{ Shepard Glacier } & 1164 & 0.107 & 0.006 & 2330 & 33.4 & 68.5 \\
\hline & 1168 & 0.007 & 0.001 & 2217 & 4.4 & 8.9 \\
\hline & 1169 & 0.003 & 0.000 & 2981 & 35.9 & 59.8 \\
\hline & 1171 & 0.003 & 0.000 & 2355 & 23.3 & 85.0 \\
\hline & 1172 & 0.190 & 0.025 & 1738 & 25.4 & 56.9 \\
\hline & 1176 & 0.061 & 0.008 & 2333 & 40.3 & 354.9 \\
\hline & 1178 & 0.003 & 0.000 & 2314 & 14.8 & 34.0 \\
\hline \multirow[t]{7}{*}{ Chaney Glacier } & 1185 & 0.410 & 0.025 & 2252 & 17.9 & 26.6 \\
\hline & 1186 & 0.004 & 0.001 & 2046 & 35.2 & 25.1 \\
\hline & 1189 & 0.009 & 0.001 & 2122 & 42.1 & 316.4 \\
\hline & 1190 & 0.090 & 0.005 & 2149 & 29.0 & 57.6 \\
\hline & 1191 & 0.002 & 0.000 & 2178 & 38.2 & 275.1 \\
\hline & 1193 & 0.012 & 0.002 & 2735 & 47.0 & 126.7 \\
\hline & 1194 & 0.001 & 0.000 & 2103 & 38.8 & 18.3 \\
\hline \multirow[t]{5}{*}{ Ipasha Glacier } & 1195 & 0.217 & 0.013 & 2288 & 20.8 & 26.8 \\
\hline & 1196 & 0.011 & 0.001 & 2038 & 30.3 & 30.0 \\
\hline & 1197 & 0.001 & 0.000 & 2021 & 38.5 & 332.5 \\
\hline & 1199 & 0.026 & 0.003 & 2492 & 29.8 & 297.0 \\
\hline & 1200 & 0.001 & 0.000 & 2111 & 45.9 & 354.7 \\
\hline Two Ocean Glacier & 1201 & 0.258 & 0.015 & 2585 & 15.1 & 92.1 \\
\hline \multirow[t]{10}{*}{ Ahern Glacier } & 1202 & 0.510 & 0.031 & 2489 & 12.0 & 85.2 \\
\hline & 1203 & 0.004 & 0.001 & 2197 & 38.6 & 142.0 \\
\hline & 1204 & 0.002 & 0.000 & 2684 & 43.3 & 103.1 \\
\hline & 1208 & 0.004 & 0.000 & 2410 & 31.7 & 306.8 \\
\hline & 1210 & 0.003 & 0.000 & 2666 & 35.0 & 72.8 \\
\hline & 1212 & 0.002 & 0.000 & 2267 & 25.0 & 68.3 \\
\hline & 1216 & 0.001 & 0.000 & 2644 & 31.0 & 125.4 \\
\hline & 1218 & 0.001 & 0.000 & 2526 & 25.7 & 195.5 \\
\hline & 1219 & 0.018 & 0.002 & 2475 & 18.6 & 4.8 \\
\hline & 1222 & 0.004 & 0.000 & 2502 & 22.7 & 186.4 \\
\hline \multirow[t]{3}{*}{ Vulture Glacier } & 1224 & 0.335 & 0.020 & 2565 & 32.0 & 81.9 \\
\hline & 1227 & 0.101 & 0.013 & 1785 & 31.5 & 74.5 \\
\hline & 1229 & 0.034 & 0.004 & 2703 & 33.3 & 142.8 \\
\hline
\end{tabular}




\begin{tabular}{|c|c|c|c|c|c|c|}
\hline Glacier Name & RECNO & $\begin{array}{r}\text { Area } \\
\left(\mathrm{km}^{2}\right)\end{array}$ & $\begin{array}{r}\text { Uncert } \\
\left(\mathbf{k m}^{2}\right)\end{array}$ & $\begin{array}{r}\text { Mean } \\
\text { Elevation }\end{array}$ & Slope & Aspect \\
\hline & 1230 & 0.002 & 0.000 & 2214 & 26.7 & 61.6 \\
\hline & 1231 & 0.032 & 0.004 & 1730 & 21.0 & 17.5 \\
\hline & 1236 & 0.001 & 0.000 & 2269 & 30.2 & 142.9 \\
\hline & 1238 & 0.020 & 0.003 & 2089 & 48.5 & 340.0 \\
\hline & 1243 & 0.004 & 0.001 & 2090 & 44.6 & 110.3 \\
\hline & 1250 & 0.013 & 0.002 & 2255 & 37.0 & 99.6 \\
\hline & 1253 & 0.057 & 0.007 & 2179 & 27.7 & 32.2 \\
\hline & 1254 & 0.029 & 0.004 & 2115 & 43.9 & 14.5 \\
\hline & 1255 & 0.011 & 0.003 & 2385 & 48.4 & 51.5 \\
\hline & 1256 & 0.019 & 0.002 & 1976 & 26.5 & 30.4 \\
\hline & 1257 & 0.014 & 0.001 & 2258 & 22.6 & 93.4 \\
\hline & 1258 & 0.009 & 0.001 & 2172 & 13.5 & 52.0 \\
\hline \multirow[t]{3}{*}{ Swiftcurrent Glacier } & 1259 & 0.190 & 0.011 & 2231 & 40.6 & 28.1 \\
\hline & 1260 & 0.007 & 0.001 & 2243 & 17.2 & 6.8 \\
\hline & 1261 & 0.048 & 0.003 & 2219 & 34.2 & 334.3 \\
\hline Salamander Glacier & 1271 & 0.173 & 0.010 & 2196 & 16.6 & 107.0 \\
\hline \multirow[t]{23}{*}{ Grinnell Glacier } & 1277 & 0.674 & 0.040 & 2025 & 7.4 & 14.2 \\
\hline & 1356 & 0.005 & 0.000 & 2385 & 12.0 & 6.7 \\
\hline & 1360 & 0.005 & 0.001 & 2343 & 39.3 & 11.5 \\
\hline & 1363 & 0.003 & 0.000 & 1921 & 57.6 & 28.4 \\
\hline & 1367 & 0.006 & 0.001 & 2392 & 26.9 & 359.9 \\
\hline & 1368 & 0.001 & 0.000 & 2520 & 37.5 & 60.2 \\
\hline & 1372 & 0.001 & 0.000 & 2293 & 19.4 & 357.8 \\
\hline & 1381 & 0.002 & 0.000 & 2494 & 36.6 & 3.0 \\
\hline & 1386 & 0.013 & 0.004 & 2373 & 25.8 & 65.4 \\
\hline & 1388 & 0.060 & 0.008 & 2403 & 32.0 & 104.8 \\
\hline & 1389 & 0.005 & 0.001 & 2166 & 29.3 & 109.9 \\
\hline & 1394 & 0.002 & 0.000 & 2173 & 29.1 & 111.3 \\
\hline & 1395 & 0.035 & 0.005 & 2284 & 28.6 & 89.6 \\
\hline & 1396 & 0.010 & 0.001 & 2463 & 39.3 & 266.4 \\
\hline & 1397 & 0.013 & 0.002 & 2498 & 31.5 & 64.6 \\
\hline & 1398 & 0.010 & 0.003 & 2192 & 41.5 & 10.2 \\
\hline & 1399 & 0.008 & 0.001 & 2129 & 30.2 & 28.6 \\
\hline & 1400 & 0.001 & 0.000 & 2392 & 36.9 & 140.8 \\
\hline & 1401 & 0.001 & 0.000 & 2488 & 29.9 & 52.5 \\
\hline & 1402 & 0.014 & 0.002 & 2276 & 28.7 & 157.3 \\
\hline & 1403 & 0.012 & 0.003 & 2284 & 22.3 & 297.5 \\
\hline & 1404 & 0.002 & 0.000 & 2010 & 28.8 & 51.0 \\
\hline & 1406 & 0.005 & 0.001 & 2190 & 26.8 & 61.5 \\
\hline
\end{tabular}




\begin{tabular}{|c|c|c|c|c|c|c|}
\hline Glacier Name & RECNO & $\begin{array}{r}\text { Area } \\
\left(\mathrm{km}^{2}\right)\end{array}$ & $\begin{array}{r}\text { Uncert } \\
\left(\mathbf{k m}^{2}\right)\end{array}$ & $\begin{array}{r}\text { Mean } \\
\text { Elevation }\end{array}$ & Slope & Aspect \\
\hline & 1407 & 0.002 & 0.000 & 2048 & 19.5 & 66.5 \\
\hline & 1409 & 0.007 & 0.001 & 2255 & 34.7 & 149.1 \\
\hline & 1411 & 0.001 & 0.000 & 2219 & 29.5 & 64.4 \\
\hline & 1413 & 0.068 & 0.009 & 2479 & 45.5 & 6.8 \\
\hline \multirow[t]{5}{*}{ Jackson Glacier } & 1414 & 0.960 & 0.058 & 2180 & 22.9 & 32.9 \\
\hline & 1417 & 0.002 & 0.000 & 2100 & 22.5 & 81.8 \\
\hline & 1419 & 0.067 & 0.004 & 2399 & 31.0 & 322.6 \\
\hline & 1420 & 0.003 & 0.000 & 2075 & 15.9 & 76.1 \\
\hline & 1421 & 0.239 & 0.031 & 2274 & 29.7 & 316.4 \\
\hline \multirow[t]{5}{*}{ Logan Glacier } & 1423 & 0.309 & 0.040 & 2213 & 23.4 & 38.3 \\
\hline & 1424 & 0.159 & 0.021 & 2498 & 30.4 & 323.3 \\
\hline & 1426 & 0.002 & 0.000 & 2337 & 42.2 & 351.0 \\
\hline & 1428 & 0.016 & 0.002 & 2658 & 38.6 & 87.6 \\
\hline & 1429 & 0.024 & 0.007 & 2771 & 30.8 & 85.6 \\
\hline \multirow[t]{13}{*}{ Blackfoot Glacier } & 1430 & 1.525 & 0.091 & 2288 & 16.6 & 20.5 \\
\hline & 1431 & 0.022 & 0.001 & 2418 & 36.6 & 286.4 \\
\hline & 1432 & 0.050 & 0.007 & 2789 & 45.5 & 165.1 \\
\hline & 1433 & 0.011 & 0.001 & 2572 & 43.4 & 107.3 \\
\hline & 1436 & 0.002 & 0.000 & 2286 & 35.0 & 280.3 \\
\hline & 1437 & 0.007 & 0.001 & 2023 & 38.3 & 300.9 \\
\hline & 1439 & 0.005 & 0.001 & 2597 & 46.8 & 168.0 \\
\hline & 1441 & 0.112 & 0.014 & 2434 & 36.5 & 341.4 \\
\hline & 1442 & 0.011 & 0.001 & 2481 & 34.9 & 59.6 \\
\hline & 1443 & 0.285 & 0.037 & 2395 & 21.5 & 117.7 \\
\hline & 1444 & 0.023 & 0.003 & 2502 & 40.6 & 15.0 \\
\hline & 1445 & 0.040 & 0.005 & 2336 & 35.5 & 319.3 \\
\hline & 1446 & 0.002 & 0.000 & 2289 & 26.6 & 227.5 \\
\hline \multirow[t]{12}{*}{ Red Eagle Glacier } & 1447 & 0.076 & 0.010 & 2156 & 22.1 & 32.2 \\
\hline & 1448 & 0.057 & 0.007 & 2429 & 38.5 & 312.8 \\
\hline & 1449 & 0.010 & 0.001 & 2523 & 32.3 & 350.1 \\
\hline & 1450 & 0.005 & 0.001 & 2223 & 21.1 & 133.5 \\
\hline & 1452 & 0.002 & 0.000 & 2321 & 33.2 & 125.4 \\
\hline & 1453 & 0.004 & 0.001 & 2454 & 35.1 & 170.8 \\
\hline & 1454 & 0.000 & 0.000 & 2245 & 30.5 & 120.0 \\
\hline & 1455 & 0.022 & 0.003 & 2373 & 20.8 & 148.0 \\
\hline & 1456 & 0.002 & 0.000 & 2203 & 24.4 & 158.3 \\
\hline & 1457 & 0.093 & 0.012 & 2418 & 9.6 & 70.9 \\
\hline & 1458 & 0.003 & 0.000 & 2280 & 25.8 & 133.4 \\
\hline & 1459 & 0.003 & 0.000 & 2513 & 34.0 & 92.9 \\
\hline
\end{tabular}




\begin{tabular}{|c|c|c|c|c|c|c|}
\hline Glacier Name & RECNO & $\begin{array}{l}\text { Area } \\
\left(\mathrm{km}^{2}\right)\end{array}$ & $\begin{array}{r}\text { Uncert } \\
\left(\mathrm{km}^{2}\right)\end{array}$ & $\begin{array}{r}\text { Mean } \\
\text { Elevation }\end{array}$ & Slope & Aspect \\
\hline & 1460 & 0.003 & 0.000 & 2312 & 13.5 & 113.8 \\
\hline & 1461 & 0.002 & 0.000 & 2267 & 22.2 & 135.5 \\
\hline & 1462 & 0.003 & 0.000 & 2494 & 15.7 & 226.9 \\
\hline & 1463 & 0.002 & 0.000 & 2260 & 34.6 & 209.9 \\
\hline & 1464 & 0.001 & 0.000 & 2157 & 24.1 & 148.3 \\
\hline \multirow[t]{21}{*}{ Pumpelly Glacier } & 1466 & 0.865 & 0.052 & 2527 & 24.8 & 78.2 \\
\hline & 1468 & 0.013 & 0.002 & 2165 & 23.6 & 64.2 \\
\hline & 1470 & 0.005 & 0.001 & 2055 & 18.0 & 163.3 \\
\hline & 1472 & 0.076 & 0.010 & 2527 & 29.6 & 333.7 \\
\hline & 1473 & 0.028 & 0.004 & 2157 & 24.4 & 128.2 \\
\hline & 1484 & 0.008 & 0.001 & 2248 & 15.0 & 64.5 \\
\hline & 1487 & 0.026 & 0.003 & 2481 & 34.8 & 175.3 \\
\hline & 1489 & 0.009 & 0.001 & 2758 & 40.4 & 142.3 \\
\hline & 1490 & 0.007 & 0.001 & 2349 & 33.7 & 48.6 \\
\hline & 1492 & 0.012 & 0.002 & 1905 & 13.8 & 67.4 \\
\hline & 1493 & 0.017 & 0.002 & 2337 & 34.2 & 131.8 \\
\hline & 1494 & 0.020 & 0.003 & 2076 & 23.6 & 150.8 \\
\hline & 1495 & 0.014 & 0.002 & 2173 & 35.4 & 138.3 \\
\hline & 1496 & 0.009 & 0.001 & 1852 & 14.1 & 57.1 \\
\hline & 1498 & 0.001 & 0.000 & 2182 & 26.8 & 108.7 \\
\hline & 1500 & 0.002 & 0.000 & 2171 & 21.3 & 90.4 \\
\hline & 1502 & 0.006 & 0.001 & 2251 & 32.2 & 63.9 \\
\hline & 1503 & 0.008 & 0.001 & 2514 & 30.0 & 86.8 \\
\hline & 1504 & 0.007 & 0.000 & 2398 & 26.2 & 64.1 \\
\hline & 1505 & 0.007 & 0.001 & 2649 & 18.9 & 77.3 \\
\hline & 1588 & 0.220 & 0.013 & 2420 & 9.7 & 358.1 \\
\hline Sperry Glacier & 1589 & 0.864 & 0.052 & 2384 & 14.3 & 3.0 \\
\hline Stanton Glacier & 1592 & 0.301 & 0.039 & 2505 & 19.3 & 42.5 \\
\hline \multirow[t]{3}{*}{ Grant Glacier } & 1593 & 0.281 & 0.036 & 2412 & 21.1 & 71.4 \\
\hline & 1594 & 0.001 & 0.000 & 2407 & 42.9 & 59.1 \\
\hline & 1596 & 0.001 & 0.000 & 2424 & 10.3 & 353.7 \\
\hline \multirow[t]{3}{*}{ Harrison Glacier } & 1601 & 1.335 & 0.080 & 2492 & 9.5 & 94.7 \\
\hline & 1602 & 0.181 & 0.011 & 2203 & 15.7 & 92.9 \\
\hline & 9980 & 0.180 & 0.011 & 2212 & 12.7 & 97.3 \\
\hline
\end{tabular}




\begin{tabular}{|c|c|c|c|c|c|c|}
\hline Glacier Name & RECNO & $\begin{array}{r}\text { Area } \\
\left(\mathrm{km}^{2}\right)\end{array}$ & $\begin{array}{r}\text { Uncert } \\
\left(\mathbf{k m}^{2}\right)\end{array}$ & $\begin{array}{r}\text { Mean } \\
\text { Elevation }\end{array}$ & Slope & Aspect \\
\hline & 1004 & 0.046 & 0.004 & 2375 & 12.9 & 103.2 \\
\hline & 1005 & 0.042 & 0.004 & 1994 & 27.6 & 34.2 \\
\hline & 1006 & 0.000 & 0.000 & 2096 & 27.5 & 327.1 \\
\hline & 1011 & 0.007 & 0.001 & 2214 & 40.7 & 4.5 \\
\hline & 1012 & 0.021 & 0.002 & 2404 & 30.0 & 37.1 \\
\hline \multirow[t]{11}{*}{ Herbst Glacier } & 1013 & 0.040 & 0.004 & 2245 & 32.2 & 59.4 \\
\hline & 1015 & 0.025 & 0.002 & 2459 & 41.3 & 45.7 \\
\hline & 1016 & 0.022 & 0.002 & 2559 & 38.0 & 41.9 \\
\hline & 1017 & 0.021 & 0.002 & 2311 & 40.9 & 332.2 \\
\hline & 1021 & 0.101 & 0.009 & 1713 & 19.8 & 49.6 \\
\hline & 1023 & 0.021 & 0.002 & 2173 & 20.9 & 63.7 \\
\hline & 1024 & 0.059 & 0.005 & 2293 & 25.3 & 352.5 \\
\hline & 1025 & 0.004 & 0.000 & 1647 & 35.2 & 344.2 \\
\hline & 1026 & 0.179 & 0.016 & 2443 & 42.2 & 356.2 \\
\hline & 1027 & 0.020 & 0.002 & 2352 & 42.2 & 342.1 \\
\hline & 1028 & 0.005 & 0.000 & 1905 & 45.9 & 15.6 \\
\hline \multirow[t]{7}{*}{ Hudson Glacier } & 1029 & 0.057 & 0.005 & 2142 & 41.3 & 10.7 \\
\hline & 1031 & 0.014 & 0.001 & 2139 & 28.5 & 354.9 \\
\hline & 1033 & 0.015 & 0.001 & 2301 & 46.0 & 1.5 \\
\hline & 1035 & 0.005 & 0.000 & 1943 & 30.4 & 75.3 \\
\hline & 1036 & 0.006 & 0.001 & 2346 & 47.8 & 12.9 \\
\hline & 1038 & 0.003 & 0.000 & 2137 & 45.1 & 64.2 \\
\hline & 1040 & 0.014 & 0.001 & 2076 & 38.2 & 80.2 \\
\hline \multirow[t]{3}{*}{ Boulder Glacier } & 1041 & 0.060 & 0.005 & 2369 & 25.7 & 15.4 \\
\hline & 1042 & 0.018 & 0.002 & 2470 & 21.5 & 318.4 \\
\hline & 1043 & 0.006 & 0.001 & 2438 & 32.4 & 27.0 \\
\hline \multirow[t]{6}{*}{ Harris Glacier } & 1044 & 0.033 & 0.003 & 1922 & 17.3 & 5.2 \\
\hline & 1045 & 0.100 & 0.009 & 2257 & 29.0 & 48.3 \\
\hline & 1049 & 0.056 & 0.005 & 2172 & 9.9 & 44.5 \\
\hline & 1050 & 0.018 & 0.002 & 2766 & 34.2 & 21.8 \\
\hline & 1052 & 0.062 & 0.006 & 2101 & 24.4 & 44.1 \\
\hline & 1054 & 0.002 & 0.000 & 2085 & 27.8 & 331.3 \\
\hline \multirow[t]{7}{*}{ Agassiz Glacier } & 1055 & 1.101 & 0.099 & 2376 & 13.6 & 66.0 \\
\hline & 1059 & 0.006 & 0.001 & 2084 & 28.2 & 350.3 \\
\hline & 1060 & 0.152 & 0.014 & 2127 & 31.8 & 32.5 \\
\hline & 1065 & 0.008 & 0.001 & 2195 & 40.1 & 6.1 \\
\hline & 1066 & 0.006 & 0.001 & 2246 & 39.8 & 336.6 \\
\hline & 1067 & 0.003 & 0.000 & 2364 & 8.1 & 318.4 \\
\hline & 1068 & 0.063 & 0.006 & 2172 & 32.0 & 336.5 \\
\hline
\end{tabular}




\begin{tabular}{|c|c|c|c|c|c|c|}
\hline Glacier Name & RECNO & $\begin{array}{r}\text { Area } \\
\left(\mathrm{km}^{2}\right)\end{array}$ & $\begin{array}{r}\text { Uncert } \\
\left(\mathbf{k m}^{2}\right)\end{array}$ & $\begin{array}{r}\text { Mean } \\
\text { Elevation }\end{array}$ & Slope & Aspect \\
\hline \multirow{4}{*}{ Kintla Glacier } & 1069 & 0.010 & 0.001 & 2117 & 40.1 & 338.7 \\
\hline & 1071 & 0.022 & 0.002 & 2109 & 24.0 & 43.3 \\
\hline & 1072 & 1.021 & 0.092 & 2579 & 17.1 & 13.6 \\
\hline & 1073 & 0.175 & 0.016 & 2548 & 27.5 & 328.5 \\
\hline \multirow[t]{12}{*}{ Miche Waburn } & 1074 & 0.113 & 0.010 & 2208 & 31.0 & 12.1 \\
\hline & 1075 & 0.004 & 0.000 & 2215 & 31.5 & 31.3 \\
\hline & 1076 & 0.007 & 0.001 & 2304 & 49.2 & 14.5 \\
\hline & 1077 & 0.019 & 0.002 & 2259 & 39.9 & 321.0 \\
\hline & 1079 & 0.020 & 0.002 & 2365 & 34.1 & 22.4 \\
\hline & 1081 & 0.048 & 0.004 & 2378 & 31.2 & 327.1 \\
\hline & 1082 & 0.003 & 0.000 & 2507 & 30.0 & 10.8 \\
\hline & 1084 & 0.137 & 0.012 & 2643 & 31.8 & 56.5 \\
\hline & 1085 & 0.027 & 0.002 & 2207 & 28.0 & 62.5 \\
\hline & 1086 & 0.019 & 0.002 & 2669 & 35.3 & 97.7 \\
\hline & 1087 & 0.021 & 0.002 & 2264 & 36.9 & 1.4 \\
\hline & 1088 & 0.127 & 0.011 & 2120 & 18.3 & 13.4 \\
\hline \multirow[t]{4}{*}{ Thunderbird Glacier } & 1089 & 0.127 & 0.011 & 2288 & 22.1 & 44.4 \\
\hline & 1090 & 0.003 & 0.000 & 2430 & 43.7 & 91.1 \\
\hline & 1091 & 0.076 & 0.007 & 2421 & 38.1 & 86.7 \\
\hline & 1093 & 0.029 & 0.003 & 2411 & 38.5 & 352.6 \\
\hline \multirow[t]{19}{*}{ Dixon Glacier } & 1094 & 0.186 & 0.017 & 2263 & 24.3 & 20.2 \\
\hline & 1095 & 0.008 & 0.001 & 2239 & 34.3 & 309.9 \\
\hline & 1096 & 0.027 & 0.002 & 2334 & 23.0 & 327.9 \\
\hline & 1097 & 0.057 & 0.005 & 1890 & 24.5 & 102.9 \\
\hline & 1098 & 0.007 & 0.001 & 2053 & 38.8 & 350.0 \\
\hline & 1099 & 0.010 & 0.001 & 2033 & 33.1 & 278.8 \\
\hline & 1102 & 0.036 & 0.003 & 2022 & 41.4 & 354.2 \\
\hline & 1103 & 0.002 & 0.000 & 1997 & 60.9 & 274.6 \\
\hline & 1104 & 0.014 & 0.001 & 2875 & 47.8 & 95.6 \\
\hline & 1105 & 0.018 & 0.002 & 2572 & 37.8 & 96.2 \\
\hline & 1106 & 0.013 & 0.001 & 3109 & 50.8 & 110.6 \\
\hline & 1108 & 0.045 & 0.004 & 2133 & 32.0 & 128.1 \\
\hline & 1109 & 0.045 & 0.004 & 2030 & 25.9 & 24.0 \\
\hline & 1110 & 0.146 & 0.013 & 2400 & 31.7 & 6.9 \\
\hline & 1112 & 0.006 & 0.001 & 2129 & 42.2 & 343.3 \\
\hline & 1113 & 0.011 & 0.001 & 2270 & 36.3 & 18.8 \\
\hline & 1114 & 0.012 & 0.001 & 2292 & 41.1 & 108.1 \\
\hline & 1115 & 0.017 & 0.002 & 2073 & 33.9 & 106.7 \\
\hline & 1117 & 0.007 & 0.001 & 2477 & 47.6 & 41.2 \\
\hline
\end{tabular}




\begin{tabular}{|c|c|c|c|c|c|c|}
\hline Glacier Name & RECNO & $\begin{array}{r}\text { Area } \\
\left(\mathrm{km}^{2}\right)\end{array}$ & $\begin{array}{r}\text { Uncert } \\
\left(\mathbf{k m}^{2}\right)\end{array}$ & $\begin{array}{r}\text { Mean } \\
\text { Elevation }\end{array}$ & Slope & Aspect \\
\hline \multirow[t]{2}{*}{ Whitecrow Glacier } & 1118 & 0.157 & 0.014 & 2004 & 19.9 & 93.1 \\
\hline & 1119 & 0.013 & 0.001 & 2518 & 52.2 & 1.7 \\
\hline \multirow[t]{4}{*}{ Baby Glacier } & 1120 & 0.078 & 0.007 & 2067 & 20.5 & 59.9 \\
\hline & 1122 & 0.002 & 0.000 & 2136 & 26.9 & 159.1 \\
\hline & 1123 & 0.004 & 0.000 & 2374 & 43.1 & 68.6 \\
\hline & 1125 & 0.004 & 0.000 & 2267 & 35.7 & 135.6 \\
\hline \multicolumn{7}{|l|}{ Weasel Collar } \\
\hline \multirow[t]{6}{*}{ Glacier } & 1126 & 0.506 & 0.046 & 2185 & 8.8 & 15.5 \\
\hline & 1127 & 0.028 & 0.002 & 2296 & 20.8 & 346.7 \\
\hline & 1128 & 0.048 & 0.004 & 2590 & 37.7 & 42.5 \\
\hline & 1129 & 0.016 & 0.001 & 1790 & 25.1 & 1.8 \\
\hline & 1130 & 0.020 & 0.002 & 2245 & 30.5 & 92.4 \\
\hline & 1131 & 0.037 & 0.003 & 1899 & 32.6 & 354.4 \\
\hline \multirow[t]{7}{*}{ Carter Glaciers } & 1132 & 0.245 & 0.022 & 2359 & 18.9 & 40.3 \\
\hline & 1133 & 0.022 & 0.002 & 2270 & 27.3 & 109.2 \\
\hline & 1134 & 0.032 & 0.003 & 1970 & 26.2 & 342.3 \\
\hline & 1135 & 0.016 & 0.001 & 2428 & 28.7 & 64.4 \\
\hline & 1137 & 0.004 & 0.000 & 2596 & 32.7 & 185.5 \\
\hline & 1138 & 0.009 & 0.001 & 2614 & 27.4 & 331.5 \\
\hline & 1140 & 0.040 & 0.004 & 2512 & 26.6 & 164.6 \\
\hline \multirow[t]{7}{*}{ Rainbow Glacier } & 1141 & 1.144 & 0.103 & 2495 & 11.2 & 96.4 \\
\hline & 1143 & 0.022 & 0.002 & 2268 & 22.4 & 54.5 \\
\hline & 1144 & 0.026 & 0.002 & 2238 & 28.1 & 85.7 \\
\hline & 1146 & 0.030 & 0.003 & 2479 & 37.2 & 38.5 \\
\hline & 1148 & 0.017 & 0.001 & 2185 & 20.2 & 18.7 \\
\hline & 1149 & 0.007 & 0.001 & 2198 & 34.2 & 16.6 \\
\hline & 1150 & 0.213 & 0.019 & 2316 & 20.8 & 70.2 \\
\hline \multirow[t]{4}{*}{ Carter Glaciers } & 1151 & 0.062 & 0.006 & 2198 & 17.7 & 94.7 \\
\hline & 1152 & 0.015 & 0.001 & 2164 & 23.6 & 33.1 \\
\hline & 1154 & 0.006 & 0.001 & 2128 & 44.7 & 357.2 \\
\hline & 1155 & 0.064 & 0.006 & 2345 & 28.8 & 346.1 \\
\hline \multirow[t]{4}{*}{ Old Sun Glacier } & 1156 & 0.383 & 0.034 & 2673 & 16.8 & 97.3 \\
\hline & 1157 & 0.041 & 0.004 & 2242 & 32.8 & 359.1 \\
\hline & 1160 & 0.022 & 0.002 & 2221 & 30.1 & 102.3 \\
\hline & 1163 & 0.002 & 0.000 & 2908 & 43.6 & 12.5 \\
\hline \multirow[t]{4}{*}{ Shepard Glacier } & 1164 & 0.107 & 0.010 & 2330 & 33.4 & 68.5 \\
\hline & 1168 & 0.008 & 0.001 & 2217 & 4.4 & 8.9 \\
\hline & 1169 & 0.003 & 0.000 & 2981 & 35.9 & 59.8 \\
\hline & 1171 & 0.003 & 0.000 & 2355 & 23.3 & 85.0 \\
\hline
\end{tabular}




\begin{tabular}{|c|c|c|c|c|c|c|}
\hline Glacier Name & RECNO & $\begin{array}{r}\text { Area } \\
\left(\mathrm{km}^{2}\right)\end{array}$ & $\begin{array}{r}\text { Uncert } \\
\left(\mathbf{k m}^{2}\right)\end{array}$ & $\begin{array}{r}\text { Mean } \\
\text { Elevation }\end{array}$ & Slope & Aspect \\
\hline & 1172 & 0.179 & 0.016 & 1738 & 25.4 & 56.9 \\
\hline & 1176 & 0.068 & 0.006 & 2333 & 40.3 & 354.9 \\
\hline & 1178 & 0.005 & 0.000 & 2314 & 14.8 & 34.0 \\
\hline & 1183 & 0.003 & 0.000 & 2214 & 50.1 & 357.7 \\
\hline \multirow[t]{8}{*}{ Chaney Glacier } & 1185 & 0.392 & 0.035 & 2252 & 17.9 & 26.6 \\
\hline & 1186 & 0.003 & 0.000 & 2046 & 35.2 & 25.1 \\
\hline & 1189 & 0.011 & 0.001 & 2122 & 42.1 & 316.4 \\
\hline & 1190 & 0.078 & 0.007 & 2149 & 29.0 & 57.6 \\
\hline & 1191 & 0.002 & 0.000 & 2178 & 38.2 & 275.1 \\
\hline & 1192 & 0.005 & 0.000 & 2071 & 40.6 & 7.3 \\
\hline & 1193 & 0.013 & 0.001 & 2735 & 47.0 & 126.7 \\
\hline & 1194 & 0.001 & 0.000 & 2103 & 38.8 & 18.3 \\
\hline \multirow[t]{5}{*}{ Ipasha Glacier } & 1195 & 0.227 & 0.020 & 2288 & 20.8 & 26.8 \\
\hline & 1196 & 0.015 & 0.001 & 2038 & 30.3 & 30.0 \\
\hline & 1197 & 0.003 & 0.000 & 2021 & 38.5 & 332.5 \\
\hline & 1199 & 0.038 & 0.003 & 2492 & 29.8 & 297.0 \\
\hline & 1200 & 0.002 & 0.000 & 2111 & 45.9 & 354.7 \\
\hline Two Ocean Glacier & 1201 & 0.278 & 0.025 & 2585 & 15.1 & 92.1 \\
\hline \multirow[t]{10}{*}{ Ahern Glacier } & 1202 & 0.512 & 0.046 & 2489 & 12.0 & 85.2 \\
\hline & 1203 & 0.003 & 0.000 & 2197 & 38.6 & 142.0 \\
\hline & 1204 & 0.003 & 0.000 & 2684 & 43.3 & 103.1 \\
\hline & 1208 & 0.005 & 0.000 & 2410 & 31.7 & 306.8 \\
\hline & 1210 & 0.007 & 0.001 & 2666 & 35.0 & 72.8 \\
\hline & 1212 & 0.009 & 0.001 & 2267 & 25.0 & 68.3 \\
\hline & 1216 & 0.013 & 0.001 & 2644 & 31.0 & 125.4 \\
\hline & 1218 & 0.003 & 0.000 & 2526 & 25.7 & 195.5 \\
\hline & 1219 & 0.024 & 0.002 & 2475 & 18.6 & 4.8 \\
\hline & 1222 & 0.010 & 0.001 & 2502 & 22.7 & 186.4 \\
\hline \multirow[t]{11}{*}{ Vulture Glacier } & 1224 & 0.331 & 0.030 & 2565 & 32.0 & 81.9 \\
\hline & 1227 & 0.098 & 0.009 & 1785 & 31.5 & 74.5 \\
\hline & 1228 & 0.016 & 0.001 & 1971 & 44.0 & 6.8 \\
\hline & 1229 & 0.034 & 0.003 & 2703 & 33.3 & 142.8 \\
\hline & 1230 & 0.007 & 0.001 & 2214 & 26.7 & 61.6 \\
\hline & 1231 & 0.039 & 0.003 & 1730 & 21.0 & 17.5 \\
\hline & 1236 & 0.005 & 0.000 & 2269 & 30.2 & 142.9 \\
\hline & 1237 & 0.010 & 0.001 & 2284 & 30.1 & 30.0 \\
\hline & 1238 & 0.018 & 0.002 & 2089 & 48.5 & 340.0 \\
\hline & 1239 & 0.007 & 0.001 & 1975 & 33.3 & 136.7 \\
\hline & 1240 & 0.033 & 0.003 & 1878 & 9.7 & 78.0 \\
\hline
\end{tabular}




\begin{tabular}{|c|c|c|c|c|c|c|}
\hline Glacier Name & RECNO & $\begin{array}{r}\text { Area } \\
\left(\mathrm{km}^{2}\right)\end{array}$ & $\begin{array}{r}\text { Uncert } \\
\left(\mathbf{k m}^{2}\right)\end{array}$ & $\begin{array}{r}\text { Mean } \\
\text { Elevation }\end{array}$ & Slope & Aspect \\
\hline & 1242 & 0.005 & 0.000 & 2191 & 19.4 & 19.0 \\
\hline & 1243 & 0.004 & 0.000 & 2090 & 44.6 & 110.3 \\
\hline & 1246 & 0.021 & 0.002 & 2035 & 38.3 & 62.7 \\
\hline & 1248 & 0.012 & 0.001 & 2178 & 14.4 & 46.9 \\
\hline & 1249 & 0.099 & 0.009 & 2084 & 31.9 & 40.3 \\
\hline & 1250 & 0.019 & 0.002 & 2255 & 37.0 & 99.6 \\
\hline & 1253 & 0.057 & 0.005 & 2179 & 27.7 & 32.2 \\
\hline & 1254 & 0.031 & 0.003 & 2115 & 43.9 & 14.5 \\
\hline & 1255 & 0.013 & 0.001 & 2385 & 48.4 & 51.5 \\
\hline & 1256 & 0.016 & 0.001 & 1976 & 26.5 & 30.4 \\
\hline & 1257 & 0.024 & 0.002 & 2258 & 22.6 & 93.4 \\
\hline & 1258 & 0.024 & 0.002 & 2172 & 13.5 & 52.0 \\
\hline \multirow[t]{10}{*}{ Swiftcurrent Glacier } & 1259 & 0.178 & 0.016 & 2231 & 40.6 & 28.1 \\
\hline & 1260 & 0.007 & 0.001 & 2243 & 17.2 & 6.8 \\
\hline & 1261 & 0.046 & 0.004 & 2219 & 34.2 & 334.3 \\
\hline & 1262 & 0.001 & 0.000 & 2048 & 6.2 & 335.8 \\
\hline & 1263 & 0.003 & 0.000 & 2304 & 37.4 & 65.8 \\
\hline & 1264 & 0.010 & 0.001 & 2120 & 28.5 & 338.3 \\
\hline & 1266 & 0.040 & 0.004 & 2294 & 18.9 & 6.5 \\
\hline & 1268 & 0.023 & 0.002 & 2097 & 23.3 & 45.6 \\
\hline & 1269 & 0.001 & 0.000 & 2243 & 30.3 & 154.5 \\
\hline & 1270 & 0.004 & 0.000 & 2211 & 20.9 & 39.9 \\
\hline \multirow[t]{4}{*}{ Salamander Glacier } & 1271 & 0.183 & 0.016 & 2196 & 16.6 & 107.0 \\
\hline & 1272 & 0.004 & 0.000 & 2471 & 41.2 & 34.7 \\
\hline & 1274 & 0.010 & 0.001 & 2390 & 46.1 & 349.7 \\
\hline & 1276 & 0.001 & 0.000 & 2172 & 39.7 & 84.2 \\
\hline \multirow[t]{5}{*}{ Grinnell Glacier } & 1277 & 0.616 & 0.055 & 2025 & 7.4 & 14.2 \\
\hline & 1278 & 0.011 & 0.001 & 2635 & 41.1 & 65.6 \\
\hline & 1280 & 0.017 & 0.002 & 2220 & 34.8 & 359.8 \\
\hline & 1281 & 0.003 & 0.000 & 2058 & 39.4 & 276.3 \\
\hline & 1282 & 0.013 & 0.001 & 2379 & 36.6 & 144.7 \\
\hline \multirow[t]{8}{*}{ Gem Glacier } & 1283 & 0.027 & 0.002 & 2511 & 38.6 & 36.0 \\
\hline & 1284 & 0.060 & 0.005 & 2017 & 21.0 & 50.4 \\
\hline & 1285 & 0.045 & 0.004 & 1977 & 43.7 & 329.5 \\
\hline & 1286 & 0.006 & 0.001 & 2146 & 35.2 & 92.3 \\
\hline & 1287 & 0.022 & 0.002 & 2646 & 42.4 & 356.7 \\
\hline & 1288 & 0.044 & 0.004 & 1730 & 25.6 & 92.8 \\
\hline & 1289 & 0.008 & 0.001 & 1837 & 33.7 & 341.1 \\
\hline & 1290 & 0.010 & 0.001 & 2110 & 25.6 & 341.7 \\
\hline
\end{tabular}




\begin{tabular}{|c|c|c|c|c|c|c|}
\hline Glacier Name & RECNO & $\begin{array}{r}\text { Area } \\
\left(\mathrm{km}^{2}\right)\end{array}$ & $\begin{array}{r}\text { Uncert } \\
\left(\mathbf{k m}^{2}\right)\end{array}$ & $\begin{array}{r}\text { Mean } \\
\text { Elevation }\end{array}$ & Slope & Aspect \\
\hline & 1291 & 0.074 & 0.007 & 2166 & 16.9 & 94.8 \\
\hline & 1292 & 0.002 & 0.000 & 2144 & 26.0 & 98.4 \\
\hline & 1293 & 0.008 & 0.001 & 2252 & 38.9 & 356.7 \\
\hline & 1294 & 0.001 & 0.000 & 2117 & 49.4 & 30.1 \\
\hline \multirow[t]{25}{*}{ Siyeh Glacier } & 1296 & 0.211 & 0.019 & 2106 & 18.5 & 17.0 \\
\hline & 1297 & 0.002 & 0.000 & 2162 & 42.2 & 7.3 \\
\hline & 1298 & 0.003 & 0.000 & 2205 & 37.9 & 8.3 \\
\hline & 1299 & 0.002 & 0.000 & 2270 & 48.6 & 4.6 \\
\hline & 1300 & 0.004 & 0.000 & 2639 & 39.0 & 99.5 \\
\hline & 1301 & 0.002 & 0.000 & 2420 & 39.3 & 133.9 \\
\hline & 1302 & 0.012 & 0.001 & 2325 & 35.6 & 97.1 \\
\hline & 1303 & 0.015 & 0.001 & 2039 & 42.7 & 64.3 \\
\hline & 1304 & 0.005 & 0.000 & 2036 & 26.1 & 71.0 \\
\hline & 1305 & 0.069 & 0.006 & 1974 & 20.4 & 27.3 \\
\hline & 1306 & 0.012 & 0.001 & 2021 & 20.4 & 327.5 \\
\hline & 1307 & 0.003 & 0.000 & 2326 & 33.0 & 107.8 \\
\hline & 1308 & 0.113 & 0.010 & 2118 & 24.6 & 35.0 \\
\hline & 1310 & 0.015 & 0.001 & 2307 & 27.3 & 40.4 \\
\hline & 1311 & 0.001 & 0.000 & 2222 & 16.8 & 144.9 \\
\hline & 1312 & 0.013 & 0.001 & 2272 & 30.0 & 353.4 \\
\hline & 1313 & 0.033 & 0.003 & 2323 & 30.9 & 117.4 \\
\hline & 1314 & 0.002 & 0.000 & 2511 & 39.7 & 64.0 \\
\hline & 1315 & 0.025 & 0.002 & 2214 & 21.3 & 93.1 \\
\hline & 1317 & 0.014 & 0.001 & 2207 & 35.7 & 356.3 \\
\hline & 1318 & 0.032 & 0.003 & 2618 & 23.1 & 37.0 \\
\hline & 1319 & 0.018 & 0.002 & 2315 & 27.5 & 10.4 \\
\hline & 1320 & 0.007 & 0.001 & 2466 & 23.6 & 93.1 \\
\hline & 1321 & 0.015 & 0.001 & 2181 & 35.7 & 78.0 \\
\hline & 1322 & 0.011 & 0.001 & 2340 & 24.4 & 151.5 \\
\hline \multirow[t]{4}{*}{ Piegan Glacier } & 1323 & 0.261 & 0.024 & 2512 & 16.4 & 54.3 \\
\hline & 1324 & 0.002 & 0.000 & 2205 & 11.7 & 146.5 \\
\hline & 1325 & 0.018 & 0.002 & 2471 & 45.2 & 128.1 \\
\hline & 1326 & 0.079 & 0.007 & 2071 & 21.0 & 94.6 \\
\hline \multirow[t]{6}{*}{ Sexton Glacier } & 1329 & 0.370 & 0.033 & 2225 & 24.2 & 76.3 \\
\hline & 1330 & 0.024 & 0.002 & 2171 & 27.1 & 64.7 \\
\hline & 1332 & 0.025 & 0.002 & 2348 & 39.3 & 113.4 \\
\hline & 1333 & 0.008 & 0.001 & 2142 & 40.5 & 123.4 \\
\hline & 1334 & 0.007 & 0.001 & 2089 & 41.1 & 359.0 \\
\hline & 1335 & 0.014 & 0.001 & 2414 & 30.2 & 51.6 \\
\hline
\end{tabular}




\begin{tabular}{|c|c|c|c|c|c|c|}
\hline Glacier Name & RECNO & $\begin{array}{r}\text { Area } \\
\left(\mathrm{km}^{2}\right)\end{array}$ & $\begin{array}{r}\text { Uncert } \\
\left(\mathbf{k m}^{2}\right)\end{array}$ & $\begin{array}{r}\text { Mean } \\
\text { Elevation }\end{array}$ & Slope & Aspect \\
\hline & 1336 & 0.006 & 0.001 & 1728 & 28.2 & 357.5 \\
\hline & 1337 & 0.012 & 0.001 & 2547 & 43.5 & 9.0 \\
\hline & 1338 & 0.019 & 0.002 & 2189 & 24.5 & 58.1 \\
\hline & 1339 & 0.057 & 0.005 & 2013 & 31.1 & 8.7 \\
\hline & 1340 & 0.049 & 0.004 & 2096 & 23.7 & 345.6 \\
\hline & 1341 & 0.009 & 0.001 & 2123 & 26.7 & 49.5 \\
\hline & 1343 & 0.048 & 0.004 & 2240 & 26.9 & 113.0 \\
\hline & 1344 & 0.002 & 0.000 & 2257 & 36.5 & 47.4 \\
\hline & 1345 & 0.003 & 0.000 & 2204 & 23.7 & 28.9 \\
\hline & 1346 & 0.006 & 0.001 & 2058 & 26.8 & 4.4 \\
\hline & 1347 & 0.039 & 0.004 & 2357 & 34.2 & 358.4 \\
\hline & 1349 & 0.002 & 0.000 & 2062 & 48.3 & 359.1 \\
\hline & 1352 & 0.079 & 0.007 & 2624 & 41.4 & 36.3 \\
\hline & 1353 & 0.052 & 0.005 & 2275 & 25.7 & 76.2 \\
\hline & 1354 & 0.002 & 0.000 & 2234 & 27.3 & 96.4 \\
\hline & 1355 & 0.003 & 0.000 & 2556 & 17.4 & 86.1 \\
\hline & 1356 & 0.005 & 0.000 & 2385 & 12.0 & 6.7 \\
\hline & 1357 & 0.014 & 0.001 & 2399 & 40.5 & 134.3 \\
\hline & 1360 & 0.010 & 0.001 & 2343 & 39.3 & 11.5 \\
\hline & 1361 & 0.085 & 0.008 & 2076 & 34.5 & 38.5 \\
\hline & 1362 & 0.105 & 0.009 & 2132 & 23.5 & 56.5 \\
\hline & 1363 & 0.003 & 0.000 & 1921 & 57.6 & 28.4 \\
\hline & 1367 & 0.010 & 0.001 & 2392 & 26.9 & 359.9 \\
\hline & 1368 & 0.003 & 0.000 & 2520 & 37.5 & 60.2 \\
\hline & 1370 & 0.004 & 0.000 & 2210 & 36.8 & 4.0 \\
\hline & 1372 & 0.008 & 0.001 & 2293 & 19.4 & 357.8 \\
\hline & 1373 & 0.008 & 0.001 & 2362 & 27.4 & 94.9 \\
\hline & 1374 & 0.003 & 0.000 & 2333 & 22.9 & 152.4 \\
\hline & 1375 & 0.061 & 0.005 & 2460 & 26.1 & 109.8 \\
\hline & 1376 & 0.009 & 0.001 & 2198 & 36.9 & 24.2 \\
\hline & 1378 & 0.024 & 0.002 & 2370 & 49.9 & 24.2 \\
\hline & 1379 & 0.227 & 0.020 & 2340 & 8.0 & 72.4 \\
\hline & 1380 & 0.032 & 0.003 & 2510 & 38.0 & 118.0 \\
\hline & 1381 & 0.002 & 0.000 & 2494 & 36.6 & 3.0 \\
\hline & 1384 & 0.109 & 0.010 & 2414 & 23.1 & 35.6 \\
\hline & 1385 & 0.006 & 0.001 & 2053 & 31.4 & 41.9 \\
\hline & 1386 & 0.021 & 0.002 & 2373 & 25.8 & 65.4 \\
\hline & 1387 & 0.003 & 0.000 & 2353 & 33.1 & 88.1 \\
\hline & 1388 & 0.067 & 0.006 & 2403 & 32.0 & 104.8 \\
\hline
\end{tabular}




\begin{tabular}{|c|c|c|c|c|c|c|}
\hline Glacier Name & RECNO & $\begin{array}{r}\text { Area } \\
\left(\mathrm{km}^{2}\right)\end{array}$ & $\begin{array}{r}\text { Uncert } \\
\left(\mathbf{k m}^{2}\right) \\
\end{array}$ & $\begin{array}{r}\text { Mean } \\
\text { Elevation }\end{array}$ & Slope & Aspect \\
\hline & 1389 & 0.009 & 0.001 & 2166 & 29.3 & 109.9 \\
\hline & 1390 & 0.008 & 0.001 & 2354 & 37.4 & 46.5 \\
\hline & 1391 & 0.017 & 0.002 & 2354 & 38.6 & 23.0 \\
\hline & 1392 & 0.024 & 0.002 & 2246 & 36.5 & 12.0 \\
\hline & 1393 & 0.019 & 0.002 & 2463 & 31.2 & 7.4 \\
\hline & 1394 & 0.003 & 0.000 & 2173 & 29.1 & 111.3 \\
\hline & 1395 & 0.039 & 0.004 & 2284 & 28.6 & 89.6 \\
\hline & 1396 & 0.012 & 0.001 & 2463 & 39.3 & 266.4 \\
\hline & 1397 & 0.009 & 0.001 & 2498 & 31.5 & 64.6 \\
\hline & 1398 & 0.024 & 0.002 & 2192 & 41.5 & 10.2 \\
\hline & 1399 & 0.008 & 0.001 & 2129 & 30.2 & 28.6 \\
\hline & 1400 & 0.006 & 0.001 & 2392 & 36.9 & 140.8 \\
\hline & 1401 & 0.003 & 0.000 & 2488 & 29.9 & 52.5 \\
\hline & 1402 & 0.017 & 0.002 & 2276 & 28.7 & 157.3 \\
\hline & 1403 & 0.022 & 0.002 & 2284 & 22.3 & 297.5 \\
\hline & 1404 & 0.003 & 0.000 & 2010 & 28.8 & 51.0 \\
\hline & 1406 & 0.006 & 0.001 & 2190 & 26.8 & 61.5 \\
\hline & 1407 & 0.005 & 0.000 & 2048 & 19.5 & 66.5 \\
\hline & 1409 & 0.009 & 0.001 & 2255 & 34.7 & 149.1 \\
\hline & 1411 & 0.004 & 0.000 & 2219 & 29.5 & 64.4 \\
\hline & 1413 & 0.070 & 0.006 & 2479 & 45.5 & 6.8 \\
\hline \multirow[t]{5}{*}{ Jackson Glacier } & 1414 & 0.999 & 0.090 & 2180 & 22.9 & 32.9 \\
\hline & 1417 & 0.002 & 0.000 & 2100 & 22.5 & 81.8 \\
\hline & 1419 & 0.082 & 0.007 & 2399 & 31.0 & 322.6 \\
\hline & 1420 & 0.008 & 0.001 & 2075 & 15.9 & 76.1 \\
\hline & 1421 & 0.231 & 0.021 & 2274 & 29.7 & 316.4 \\
\hline \multirow[t]{5}{*}{ Logan Glacier } & 1423 & 0.317 & 0.029 & 2213 & 23.4 & 38.3 \\
\hline & 1424 & 0.166 & 0.015 & 2498 & 30.4 & 323.3 \\
\hline & 1426 & 0.002 & 0.000 & 2337 & 42.2 & 351.0 \\
\hline & 1428 & 0.014 & 0.001 & 2658 & 38.6 & 87.6 \\
\hline & 1429 & 0.026 & 0.002 & 2771 & 30.8 & 85.6 \\
\hline \multirow[t]{8}{*}{ Blackfoot Glacier } & 1430 & 1.559 & 0.140 & 2288 & 16.6 & 20.5 \\
\hline & 1431 & 0.021 & 0.002 & 2418 & 36.6 & 286.4 \\
\hline & 1432 & 0.050 & 0.005 & 2789 & 45.5 & 165.1 \\
\hline & 1433 & 0.010 & 0.001 & 2572 & 43.4 & 107.3 \\
\hline & 1435 & 0.099 & 0.009 & 2136 & 22.4 & 12.1 \\
\hline & 1436 & 0.003 & 0.000 & 2286 & 35.0 & 280.3 \\
\hline & 1437 & 0.005 & 0.000 & 2023 & 38.3 & 300.9 \\
\hline & 1439 & 0.004 & 0.000 & 2597 & 46.8 & 168.0 \\
\hline
\end{tabular}




\begin{tabular}{|c|c|c|c|c|c|c|}
\hline Glacier Name & RECNO & $\begin{array}{r}\text { Area } \\
\left(\mathrm{km}^{2}\right)\end{array}$ & $\begin{array}{r}\text { Uncert } \\
\left(\mathbf{k m}^{2}\right)\end{array}$ & $\begin{array}{r}\text { Mean } \\
\text { Elevation }\end{array}$ & Slope & Aspect \\
\hline & 1441 & 0.106 & 0.010 & 2434 & 36.5 & 341.4 \\
\hline & 1442 & 0.012 & 0.001 & 2481 & 34.9 & 59.6 \\
\hline & 1443 & 0.302 & 0.027 & 2395 & 21.5 & 117.7 \\
\hline & 1444 & 0.025 & 0.002 & 2502 & 40.6 & 15.0 \\
\hline & 1445 & 0.039 & 0.003 & 2336 & 35.5 & 319.3 \\
\hline & 1446 & 0.002 & 0.000 & 2289 & 26.6 & 227.5 \\
\hline \multirow[t]{17}{*}{ Red Eagle Glacier } & 1447 & 0.117 & 0.011 & 2156 & 22.1 & 32.2 \\
\hline & 1448 & 0.057 & 0.005 & 2429 & 38.5 & 312.8 \\
\hline & 1449 & 0.010 & 0.001 & 2523 & 32.3 & 350.1 \\
\hline & 1450 & 0.011 & 0.001 & 2223 & 21.1 & 133.5 \\
\hline & 1452 & 0.001 & 0.000 & 2321 & 33.2 & 125.4 \\
\hline & 1453 & 0.006 & 0.001 & 2454 & 35.1 & 170.8 \\
\hline & 1454 & 0.001 & 0.000 & 2245 & 30.5 & 120.0 \\
\hline & 1455 & 0.028 & 0.002 & 2373 & 20.8 & 148.0 \\
\hline & 1456 & 0.004 & 0.000 & 2203 & 24.4 & 158.3 \\
\hline & 1457 & 0.096 & 0.009 & 2418 & 9.6 & 70.9 \\
\hline & 1458 & 0.004 & 0.000 & 2280 & 25.8 & 133.4 \\
\hline & 1459 & 0.005 & 0.000 & 2513 & 34.0 & 92.9 \\
\hline & 1460 & 0.005 & 0.000 & 2312 & 13.5 & 113.8 \\
\hline & 1461 & 0.003 & 0.000 & 2267 & 22.2 & 135.5 \\
\hline & 1462 & 0.008 & 0.001 & 2494 & 15.7 & 226.9 \\
\hline & 1463 & 0.001 & 0.000 & 2260 & 34.6 & 209.9 \\
\hline & 1464 & 0.004 & 0.000 & 2157 & 24.1 & 148.3 \\
\hline \multirow[t]{16}{*}{ Pumpelly Glacier } & 1466 & 0.893 & 0.080 & 2527 & 24.8 & 78.2 \\
\hline & 1468 & 0.017 & 0.002 & 2165 & 23.6 & 64.2 \\
\hline & 1469 & 0.002 & 0.000 & 2209 & 9.4 & 122.9 \\
\hline & 1470 & 0.004 & 0.000 & 2055 & 18.0 & 163.3 \\
\hline & 1472 & 0.070 & 0.006 & 2527 & 29.6 & 333.7 \\
\hline & 1473 & 0.026 & 0.002 & 2157 & 24.4 & 128.2 \\
\hline & 1474 & 0.002 & 0.000 & 2168 & 6.1 & 95.7 \\
\hline & 1476 & 0.110 & 0.010 & 2212 & 20.2 & 31.1 \\
\hline & 1477 & 0.030 & 0.003 & 2140 & 16.6 & 31.3 \\
\hline & 1478 & 0.006 & 0.001 & 1839 & 48.7 & 350.2 \\
\hline & 1479 & 0.029 & 0.003 & 2112 & 37.3 & 287.9 \\
\hline & 1480 & 0.075 & 0.007 & 2181 & 30.4 & 358.8 \\
\hline & 1481 & 0.005 & 0.000 & 2059 & 33.9 & 72.3 \\
\hline & 1482 & 0.069 & 0.006 & 2031 & 17.1 & 14.6 \\
\hline & 1483 & 0.003 & 0.000 & 2330 & 44.1 & 354.9 \\
\hline & 1484 & 0.008 & 0.001 & 2248 & 15.0 & 64.5 \\
\hline
\end{tabular}




\begin{tabular}{|c|c|c|c|c|c|c|}
\hline Glacier Name & RECNO & $\begin{array}{r}\text { Area } \\
\left(\mathrm{km}^{2}\right)\end{array}$ & $\begin{array}{r}\text { Uncert } \\
\left(\mathbf{k m}^{2}\right)\end{array}$ & $\begin{array}{r}\text { Mean } \\
\text { Elevation }\end{array}$ & Slope & Aspect \\
\hline & 1485 & 0.015 & 0.001 & 2813 & 42.2 & 103.4 \\
\hline & 1486 & 0.006 & 0.001 & 2386 & 38.2 & 332.9 \\
\hline & 1487 & 0.021 & 0.002 & 2481 & 34.8 & 175.3 \\
\hline & 1488 & 0.025 & 0.002 & 2256 & 36.9 & 66.6 \\
\hline & 1489 & 0.006 & 0.001 & 2758 & 40.4 & 142.3 \\
\hline & 1490 & 0.007 & 0.001 & 2349 & 33.7 & 48.6 \\
\hline & 1491 & 0.075 & 0.007 & 2089 & 9.6 & 1.0 \\
\hline & 1492 & 0.011 & 0.001 & 1905 & 13.8 & 67.4 \\
\hline & 1493 & 0.017 & 0.001 & 2337 & 34.2 & 131.8 \\
\hline & 1494 & 0.024 & 0.002 & 2076 & 23.6 & 150.8 \\
\hline & 1495 & 0.014 & 0.001 & 2173 & 35.4 & 138.3 \\
\hline & 1496 & 0.007 & 0.001 & 1852 & 14.1 & 57.1 \\
\hline & 1498 & 0.002 & 0.000 & 2182 & 26.8 & 108.7 \\
\hline & 1500 & 0.003 & 0.000 & 2171 & 21.3 & 90.4 \\
\hline & 1502 & 0.006 & 0.001 & 2251 & 32.2 & 63.9 \\
\hline & 1503 & 0.012 & 0.001 & 2514 & 30.0 & 86.8 \\
\hline & 1504 & 0.009 & 0.001 & 2398 & 26.2 & 64.1 \\
\hline & 1505 & 0.010 & 0.001 & 2649 & 18.9 & 77.3 \\
\hline & 1506 & 0.086 & 0.008 & 2222 & 24.9 & 18.3 \\
\hline & 1507 & 0.007 & 0.001 & 2555 & 28.3 & 117.6 \\
\hline & 1508 & 0.008 & 0.001 & 2472 & 30.9 & 122.5 \\
\hline & 1509 & 0.008 & 0.001 & 2260 & 8.2 & 138.1 \\
\hline & 1510 & 0.025 & 0.002 & 1986 & 28.2 & 16.6 \\
\hline & 1511 & 0.003 & 0.000 & 2393 & 30.0 & 112.6 \\
\hline & 1512 & 0.004 & 0.000 & 2000 & 40.1 & 329.5 \\
\hline & 1513 & 0.068 & 0.006 & 2262 & 25.6 & 79.5 \\
\hline & 1514 & 0.033 & 0.003 & 2388 & 18.2 & 81.8 \\
\hline & 1515 & 0.099 & 0.009 & 2211 & 16.9 & 30.8 \\
\hline & 1516 & 0.032 & 0.003 & 2356 & 9.3 & 66.3 \\
\hline & 1517 & 0.015 & 0.001 & 2170 & 47.9 & 354.7 \\
\hline & 1518 & 0.073 & 0.007 & 2117 & 14.8 & 61.3 \\
\hline & 1519 & 0.003 & 0.000 & 2332 & 25.7 & 333.3 \\
\hline & 1520 & 0.006 & 0.001 & 2285 & 28.7 & 122.4 \\
\hline & 1521 & 0.003 & 0.000 & 2339 & 42.1 & 342.0 \\
\hline & 1522 & 0.005 & 0.000 & 1846 & 36.3 & 128.3 \\
\hline & 1523 & 0.015 & 0.001 & 2294 & 29.4 & 75.5 \\
\hline & 1524 & 0.006 & 0.001 & 2291 & 28.1 & 44.3 \\
\hline & 1525 & 0.032 & 0.003 & 2269 & 16.8 & 26.6 \\
\hline & 1526 & 0.032 & 0.003 & 1860 & 23.9 & 23.9 \\
\hline
\end{tabular}




\begin{tabular}{|c|c|c|c|c|c|c|}
\hline Glacier Name & RECNO & $\begin{array}{r}\text { Area } \\
\left(\mathrm{km}^{2}\right)\end{array}$ & $\begin{array}{r}\text { Uncert } \\
\left(\mathbf{k m}^{2}\right)\end{array}$ & $\begin{array}{r}\text { Mean } \\
\text { Elevation }\end{array}$ & Slope & Aspect \\
\hline & 1527 & 0.006 & 0.000 & 2341 & 47.9 & 7.5 \\
\hline & 1528 & 0.011 & 0.001 & 2210 & 30.1 & 79.0 \\
\hline & 1529 & 0.008 & 0.001 & 2428 & 49.0 & 4.0 \\
\hline & 1530 & 0.007 & 0.001 & 2484 & 42.6 & 5.2 \\
\hline & 1531 & 0.016 & 0.001 & 1900 & 22.1 & 67.3 \\
\hline & 1532 & 0.009 & 0.001 & 2312 & 26.7 & 60.5 \\
\hline & 1533 & 0.011 & 0.001 & 2717 & 40.1 & 45.2 \\
\hline & 1534 & 0.222 & 0.020 & 2022 & 8.0 & 51.5 \\
\hline & 1535 & 0.030 & 0.003 & 1992 & 45.6 & 325.0 \\
\hline & 1536 & 0.034 & 0.003 & 2073 & 14.5 & 37.6 \\
\hline & 1537 & 0.002 & 0.000 & 1993 & 12.7 & 56.9 \\
\hline & 1538 & 0.017 & 0.002 & 2019 & 34.8 & 61.3 \\
\hline & 1539 & 0.012 & 0.001 & 1757 & 25.7 & 66.1 \\
\hline & 1540 & 0.039 & 0.003 & 1927 & 28.0 & 51.2 \\
\hline & 1541 & 0.015 & 0.001 & 1760 & 30.8 & 354.9 \\
\hline & 1542 & 0.001 & 0.000 & 2034 & 49.3 & 26.4 \\
\hline & 1543 & 0.113 & 0.010 & 2016 & 44.9 & 21.2 \\
\hline & 1544 & 0.022 & 0.002 & 2340 & 63.5 & 33.8 \\
\hline & 1545 & 0.009 & 0.001 & 2197 & 38.4 & 332.4 \\
\hline & 1546 & 0.006 & 0.001 & 2309 & 42.7 & 342.9 \\
\hline & 1547 & 0.013 & 0.001 & 2040 & 16.6 & 1.1 \\
\hline & 1548 & 0.008 & 0.001 & 2417 & 44.8 & 76.4 \\
\hline & 1550 & 0.004 & 0.000 & 2291 & 39.8 & 65.7 \\
\hline & 1551 & 0.004 & 0.000 & 2221 & 29.8 & 18.7 \\
\hline & 1552 & 0.001 & 0.000 & 2092 & 29.9 & 29.1 \\
\hline & 1553 & 0.000 & 0.000 & 2294 & 30.1 & 32.3 \\
\hline & 1554 & 0.011 & 0.001 & 2386 & 42.2 & 94.9 \\
\hline \multirow[t]{12}{*}{ Lupfer Glacier } & 1555 & 0.101 & 0.009 & 1868 & 30.6 & 94.9 \\
\hline & 1556 & 0.014 & 0.001 & 1895 & 27.2 & 70.2 \\
\hline & 1557 & 0.037 & 0.003 & 2107 & 20.3 & 43.8 \\
\hline & 1559 & 0.006 & 0.001 & 2052 & 56.5 & 40.5 \\
\hline & 1560 & 0.033 & 0.003 & 2097 & 19.7 & 11.5 \\
\hline & 1561 & 0.032 & 0.003 & 2262 & 19.8 & 48.6 \\
\hline & 1562 & 0.007 & 0.001 & 2102 & 34.4 & 357.8 \\
\hline & 1563 & 0.018 & 0.002 & 2333 & 28.7 & 43.8 \\
\hline & 1564 & 0.008 & 0.001 & 2112 & 35.7 & 105.4 \\
\hline & 1565 & 0.011 & 0.001 & 2638 & 42.7 & 47.3 \\
\hline & 1566 & 0.022 & 0.002 & 2539 & 36.1 & 23.7 \\
\hline & 1567 & 0.013 & 0.001 & 1972 & 12.5 & 116.7 \\
\hline
\end{tabular}




\begin{tabular}{|c|c|c|c|c|c|c|}
\hline Glacier Name & RECNO & $\begin{array}{r}\text { Area } \\
\left(\mathrm{km}^{2}\right)\end{array}$ & $\begin{array}{r}\text { Uncert } \\
\left(\mathbf{k m}^{2}\right) \\
\end{array}$ & $\begin{array}{r}\text { Mean } \\
\text { Elevation }\end{array}$ & Slope & Aspect \\
\hline & 1568 & 0.101 & 0.009 & 2270 & 28.9 & 73.8 \\
\hline & 1569 & 0.017 & 0.002 & 2084 & 30.5 & 127.1 \\
\hline & 1570 & 0.006 & 0.001 & 2170 & 20.0 & 12.0 \\
\hline & 1571 & 0.005 & 0.000 & 2361 & 25.7 & 96.7 \\
\hline & 1572 & 0.035 & 0.003 & 2446 & 21.4 & 10.9 \\
\hline & 1573 & 0.038 & 0.003 & 1944 & 22.3 & 16.4 \\
\hline & 1574 & 0.002 & 0.000 & 2567 & 35.4 & 351.0 \\
\hline & 1575 & 0.009 & 0.001 & 2183 & 24.6 & 2.7 \\
\hline & 1576 & 0.003 & 0.000 & 2172 & 2.1 & 359.8 \\
\hline & 1578 & 0.026 & 0.002 & 2089 & 33.1 & 9.0 \\
\hline & 1579 & 0.010 & 0.001 & 2334 & 26.8 & 351.0 \\
\hline & 1580 & 0.020 & 0.002 & 2556 & 32.2 & 5.7 \\
\hline & 1581 & 0.023 & 0.002 & 2219 & 18.4 & 55.8 \\
\hline & 1582 & 0.055 & 0.005 & 2079 & 27.7 & 30.8 \\
\hline & 1583 & 0.021 & 0.002 & 2198 & 39.4 & 50.1 \\
\hline & 1584 & 0.005 & 0.000 & 2188 & 26.9 & 164.7 \\
\hline & 1588 & 0.274 & 0.025 & 2420 & 9.7 & 358.1 \\
\hline Sperry Glacier & 1589 & 0.886 & 0.080 & 2384 & 14.3 & 3.0 \\
\hline Stanton Glacier & 1592 & 0.306 & 0.028 & 2505 & 19.3 & 42.5 \\
\hline \multirow[t]{5}{*}{ Grant Glacier } & 1593 & 0.295 & 0.027 & 2412 & 21.1 & 71.4 \\
\hline & 1594 & 0.002 & 0.000 & 2407 & 42.9 & 59.1 \\
\hline & 1596 & 0.002 & 0.000 & 2424 & 10.3 & 353.7 \\
\hline & 1597 & 0.008 & 0.001 & 2163 & 17.8 & 9.3 \\
\hline & 1598 & 0.007 & 0.001 & 2231 & 44.0 & 328.9 \\
\hline \multirow[t]{3}{*}{ Harrison Glacier } & 1601 & 1.370 & 0.123 & 2492 & 9.5 & 94.7 \\
\hline & 1602 & 0.180 & 0.016 & 2203 & 15.7 & 92.9 \\
\hline & 9980 & 0.178 & 0.016 & 2212 & 12.7 & 97.3 \\
\hline
\end{tabular}

2013

\begin{tabular}{rrrrrrr}
\hline Glacier Name & RECNO & $\begin{array}{r}\text { Area } \\
\left.\mathbf{( k m}^{2}\right)\end{array}$ & $\begin{array}{r}\text { Uncert } \\
\left.\mathbf{( k m}^{2}\right)\end{array}$ & $\begin{array}{r}\text { Mean } \\
\text { Elevation }\end{array}$ & Slope & Aspect \\
\hline & 1005 & 0.058 & 0.005 & 1994 & 27.6 & 34.2 \\
& 1006 & 0.008 & 0.002 & 2096 & 27.5 & 327.1
\end{tabular}




\begin{tabular}{|c|c|c|c|c|c|c|}
\hline Glacier Name & RECNO & $\begin{array}{r}\text { Area } \\
\left(\mathrm{km}^{2}\right)\end{array}$ & $\begin{array}{r}\text { Uncert } \\
\left(\mathbf{k m}^{2}\right)\end{array}$ & $\begin{array}{r}\text { Mean } \\
\text { Elevation }\end{array}$ & Slope & Aspect \\
\hline & 1011 & 0.007 & 0.001 & 2214 & 40.7 & 4.5 \\
\hline & 1012 & 0.021 & 0.002 & 2404 & 30.0 & 37.1 \\
\hline \multirow[t]{9}{*}{ Herbst Glacier } & 1013 & 0.085 & 0.008 & 2245 & 32.2 & 59.4 \\
\hline & 1015 & 0.012 & 0.001 & 2459 & 41.3 & 45.7 \\
\hline & 1016 & 0.009 & 0.001 & 2559 & 38.0 & 41.9 \\
\hline & 1017 & 0.027 & 0.002 & 2311 & 40.9 & 332.2 \\
\hline & 1021 & 0.123 & 0.011 & 1713 & 19.8 & 49.6 \\
\hline & 1024 & 0.074 & 0.007 & 2293 & 25.3 & 352.5 \\
\hline & 1025 & 0.024 & 0.002 & 1647 & 35.2 & 344.2 \\
\hline & 1026 & 0.236 & 0.009 & 2443 & 42.2 & 356.2 \\
\hline & 1027 & 0.022 & 0.002 & 2352 & 42.2 & 342.1 \\
\hline \multirow[t]{6}{*}{ Hudson Glacier } & 1029 & 0.065 & 0.006 & 2142 & 41.3 & 10.7 \\
\hline & 1031 & 0.001 & 0.000 & 2139 & 28.5 & 354.9 \\
\hline & 1033 & 0.005 & 0.001 & 2301 & 46.0 & 1.5 \\
\hline & 1035 & 0.035 & 0.003 & 1943 & 30.4 & 75.3 \\
\hline & 1036 & 0.006 & 0.001 & 2346 & 47.8 & 12.9 \\
\hline & 1038 & 0.009 & 0.001 & 2137 & 45.1 & 64.2 \\
\hline \multirow[t]{7}{*}{ Boulder Glacier } & 1041 & 0.065 & 0.006 & 2369 & 25.7 & 15.4 \\
\hline & 1042 & 0.041 & 0.004 & 2470 & 21.5 & 318.4 \\
\hline & 1043 & 0.005 & 0.002 & 2438 & 32.4 & 27.0 \\
\hline & 1059 & 0.015 & 0.004 & 2084 & 28.2 & 350.3 \\
\hline & 1065 & 0.005 & 0.002 & 2195 & 40.1 & 6.1 \\
\hline & 1066 & 0.006 & 0.002 & 2246 & 39.8 & 336.6 \\
\hline & 1071 & 0.045 & 0.004 & 2109 & 24.0 & 43.3 \\
\hline \multirow[t]{4}{*}{ Miche Waburn } & 1074 & 0.115 & 0.005 & 2208 & 31.0 & 12.1 \\
\hline & 1075 & 0.003 & 0.001 & 2215 & 31.5 & 31.3 \\
\hline & 1079 & 0.035 & 0.003 & 2365 & 34.1 & 22.4 \\
\hline & 1088 & 0.109 & 0.010 & 2120 & 18.3 & 13.4 \\
\hline \multirow[t]{4}{*}{ Thunderbird Glacier } & 1089 & 0.139 & 0.013 & 2288 & 22.1 & 44.4 \\
\hline & 1090 & 0.004 & 0.000 & 2430 & 43.7 & 91.1 \\
\hline & 1091 & 0.085 & 0.008 & 2421 & 38.1 & 86.7 \\
\hline & 1093 & 0.027 & 0.002 & 2411 & 38.5 & 352.6 \\
\hline \multirow[t]{7}{*}{ Dixon Glacier } & 1094 & 0.185 & 0.017 & 2263 & 24.3 & 20.2 \\
\hline & 1095 & 0.013 & 0.004 & 2239 & 34.3 & 309.9 \\
\hline & 1096 & 0.036 & 0.003 & 2334 & 23.0 & 327.9 \\
\hline & 1098 & 0.009 & 0.003 & 2053 & 38.8 & 350.0 \\
\hline & 1102 & 0.044 & 0.013 & 2022 & 41.4 & 354.2 \\
\hline & 1104 & 0.015 & 0.001 & 2875 & 47.8 & 95.6 \\
\hline & 1105 & 0.015 & 0.001 & 2572 & 37.8 & 96.2 \\
\hline
\end{tabular}




\begin{tabular}{|c|c|c|c|c|c|c|}
\hline Glacier Name & RECNO & $\begin{array}{r}\text { Area } \\
\left(\mathrm{km}^{2}\right)\end{array}$ & $\begin{array}{r}\text { Uncert } \\
\left(\mathbf{k m}^{2}\right)\end{array}$ & $\begin{array}{r}\text { Mean } \\
\text { Elevation }\end{array}$ & Slope & Aspect \\
\hline & 1106 & 0.016 & 0.001 & 3109 & 50.8 & 110.6 \\
\hline & 1108 & 0.066 & 0.006 & 2133 & 32.0 & 128.1 \\
\hline & 1114 & 0.010 & 0.001 & 2292 & 41.1 & 108.1 \\
\hline & 1115 & 0.021 & 0.002 & 2073 & 33.9 & 106.7 \\
\hline \multirow[t]{3}{*}{ Whitecrow Glacier } & 1118 & 0.187 & 0.007 & 2004 & 19.9 & 93.1 \\
\hline & 1122 & 0.005 & 0.000 & 2136 & 26.9 & 159.1 \\
\hline & 1125 & 0.007 & 0.001 & 2267 & 35.7 & 135.6 \\
\hline \multicolumn{7}{|l|}{ Weasel Collar } \\
\hline \multirow[t]{3}{*}{ Glacier } & 1126 & 0.519 & 0.021 & 2185 & 8.8 & 15.5 \\
\hline & 1130 & 0.020 & 0.002 & 2245 & 30.5 & 92.4 \\
\hline & 1131 & 0.039 & 0.012 & 1899 & 32.6 & 354.4 \\
\hline \multirow[t]{8}{*}{ Carter Glaciers } & 1132 & 0.239 & 0.022 & 2359 & 18.9 & 40.3 \\
\hline & 1133 & 0.029 & 0.003 & 2270 & 27.3 & 109.2 \\
\hline & 1135 & 0.014 & 0.001 & 2428 & 28.7 & 64.4 \\
\hline & 1138 & 0.011 & 0.001 & 2614 & 27.4 & 331.5 \\
\hline & 1143 & 0.039 & 0.004 & 2268 & 22.4 & 54.5 \\
\hline & 1144 & 0.024 & 0.002 & 2238 & 28.1 & 85.7 \\
\hline & 1146 & 0.048 & 0.004 & 2479 & 37.2 & 38.5 \\
\hline & 1148 & 0.034 & 0.003 & 2185 & 20.2 & 18.7 \\
\hline \multirow[t]{2}{*}{ Carter Glaciers } & 1151 & 0.092 & 0.008 & 2198 & 17.7 & 94.7 \\
\hline & 1155 & 0.068 & 0.003 & 2345 & 28.8 & 346.1 \\
\hline \multirow[t]{4}{*}{ Old Sun Glacier } & 1156 & 0.380 & 0.015 & 2673 & 16.8 & 97.3 \\
\hline & 1157 & 0.048 & 0.004 & 2242 & 32.8 & 359.1 \\
\hline & 1160 & 0.036 & 0.003 & 2221 & 30.1 & 102.3 \\
\hline & 1163 & 0.001 & 0.000 & 2908 & 43.6 & 12.5 \\
\hline \multirow[t]{7}{*}{ Shepard Glacier } & 1164 & 0.108 & 0.010 & 2330 & 33.4 & 68.5 \\
\hline & 1168 & 0.012 & 0.001 & 2217 & 4.4 & 8.9 \\
\hline & 1169 & 0.002 & 0.000 & 2981 & 35.9 & 59.8 \\
\hline & 1171 & 0.004 & 0.001 & 2355 & 23.3 & 85.0 \\
\hline & 1172 & 0.214 & 0.019 & 1738 & 25.4 & 56.9 \\
\hline & 1176 & 0.070 & 0.021 & 2333 & 40.3 & 354.9 \\
\hline & 1178 & 0.008 & 0.001 & 2314 & 14.8 & 34.0 \\
\hline \multirow[t]{7}{*}{ Chaney Glacier } & 1185 & 0.382 & 0.015 & 2252 & 17.9 & 26.6 \\
\hline & 1186 & 0.006 & 0.001 & 2046 & 35.2 & 25.1 \\
\hline & 1189 & 0.011 & 0.003 & 2122 & 42.1 & 316.4 \\
\hline & 1190 & 0.130 & 0.005 & 2149 & 29.0 & 57.6 \\
\hline & 1191 & 0.002 & 0.001 & 2178 & 38.2 & 275.1 \\
\hline & 1193 & 0.017 & 0.002 & 2735 & 47.0 & 126.7 \\
\hline & 1194 & 0.002 & 0.000 & 2103 & 38.8 & 18.3 \\
\hline
\end{tabular}




\begin{tabular}{|c|c|c|c|c|c|c|}
\hline Glacier Name & RECNO & $\begin{array}{r}\text { Area } \\
\left(\mathrm{km}^{2}\right)\end{array}$ & $\begin{array}{r}\text { Uncert } \\
\left(\mathbf{k m}^{2}\right) \\
\end{array}$ & $\begin{array}{r}\text { Mean } \\
\text { Elevation }\end{array}$ & Slope & Aspect \\
\hline \multirow[t]{5}{*}{ Ipasha Glacier } & 1195 & 0.210 & 0.019 & 2288 & 20.8 & 26.8 \\
\hline & 1196 & 0.014 & 0.001 & 2038 & 30.3 & 30.0 \\
\hline & 1197 & 0.003 & 0.000 & 2021 & 38.5 & 332.5 \\
\hline & 1199 & 0.044 & 0.004 & 2492 & 29.8 & 297.0 \\
\hline & 1200 & 0.003 & 0.001 & 2111 & 45.9 & 354.7 \\
\hline Two Ocean Glacier & 1201 & 0.297 & 0.027 & 2585 & 15.1 & 92.1 \\
\hline \multirow[t]{10}{*}{ Ahern Glacier } & 1202 & 0.504 & 0.020 & 2489 & 12.0 & 85.2 \\
\hline & 1203 & 0.013 & 0.001 & 2197 & 38.6 & 142.0 \\
\hline & 1204 & 0.003 & 0.000 & 2684 & 43.3 & 103.1 \\
\hline & 1208 & 0.005 & 0.000 & 2410 & 31.7 & 306.8 \\
\hline & 1210 & 0.008 & 0.001 & 2666 & 35.0 & 72.8 \\
\hline & 1212 & 0.035 & 0.003 & 2267 & 25.0 & 68.3 \\
\hline & 1216 & 0.019 & 0.002 & 2644 & 31.0 & 125.4 \\
\hline & 1218 & 0.003 & 0.000 & 2526 & 25.7 & 195.5 \\
\hline & 1219 & 0.027 & 0.002 & 2475 & 18.6 & 4.8 \\
\hline & 1222 & 0.024 & 0.002 & 2502 & 22.7 & 186.4 \\
\hline \multirow[t]{18}{*}{ Vulture Glacier } & 1224 & 0.354 & 0.014 & 2565 & 32.0 & 81.9 \\
\hline & 1227 & 0.118 & 0.011 & 1785 & 31.5 & 74.5 \\
\hline & 1229 & 0.033 & 0.003 & 2703 & 33.3 & 142.8 \\
\hline & 1230 & 0.008 & 0.001 & 2214 & 26.7 & 61.6 \\
\hline & 1231 & 0.042 & 0.004 & 1730 & 21.0 & 17.5 \\
\hline & 1236 & 0.012 & 0.001 & 2269 & 30.2 & 142.9 \\
\hline & 1238 & 0.019 & 0.002 & 2089 & 48.5 & 340.0 \\
\hline & 1239 & 0.013 & 0.001 & 1975 & 33.3 & 136.7 \\
\hline & 1240 & 0.060 & 0.005 & 1878 & 9.7 & 78.0 \\
\hline & 1243 & 0.007 & 0.002 & 2090 & 44.6 & 110.3 \\
\hline & 1246 & 0.011 & 0.001 & 2035 & 38.3 & 62.7 \\
\hline & 1250 & 0.046 & 0.004 & 2255 & 37.0 & 99.6 \\
\hline & 1253 & 0.054 & 0.005 & 2179 & 27.7 & 32.2 \\
\hline & 1254 & 0.032 & 0.003 & 2115 & 43.9 & 14.5 \\
\hline & 1255 & 0.012 & 0.001 & 2385 & 48.4 & 51.5 \\
\hline & 1256 & 0.023 & 0.002 & 1976 & 26.5 & 30.4 \\
\hline & 1257 & 0.028 & 0.003 & 2258 & 22.6 & 93.4 \\
\hline & 1258 & 0.028 & 0.003 & 2172 & 13.5 & 52.0 \\
\hline \multirow[t]{3}{*}{ Swiftcurrent Glacier } & 1259 & 0.185 & 0.007 & 2231 & 40.6 & 28.1 \\
\hline & 1260 & 0.008 & 0.001 & 2243 & 17.2 & 6.8 \\
\hline & 1261 & 0.043 & 0.002 & 2219 & 34.2 & 334.3 \\
\hline Salamander Glacier & 1271 & 0.175 & 0.016 & 2196 & 16.6 & 107.0 \\
\hline Grinnell Glacier & 1277 & 0.608 & 0.024 & 2025 & 7.4 & 14.2 \\
\hline
\end{tabular}




\begin{tabular}{|c|c|c|c|c|c|c|}
\hline Glacier Name & RECNO & $\begin{array}{r}\text { Area } \\
\left(\mathrm{km}^{2}\right)\end{array}$ & $\begin{array}{r}\text { Uncert } \\
\left(\mathbf{k m}^{2}\right)\end{array}$ & $\begin{array}{r}\text { Mean } \\
\text { Elevation }\end{array}$ & Slope & Aspect \\
\hline & 1281 & 0.012 & 0.004 & 2058 & 39.4 & 276.3 \\
\hline \multirow[t]{7}{*}{ Gem Glacier } & 1283 & 0.024 & 0.001 & 2511 & 38.6 & 36.0 \\
\hline & 1284 & 0.068 & 0.006 & 2017 & 21.0 & 50.4 \\
\hline & 1285 & 0.047 & 0.014 & 1977 & 43.7 & 329.5 \\
\hline & 1286 & 0.011 & 0.001 & 2146 & 35.2 & 92.3 \\
\hline & 1287 & 0.020 & 0.002 & 2646 & 42.4 & 356.7 \\
\hline & 1288 & 0.046 & 0.004 & 1730 & 25.6 & 92.8 \\
\hline & 1291 & 0.073 & 0.007 & 2166 & 16.9 & 94.8 \\
\hline \multirow[t]{13}{*}{ Siyeh Glacier } & 1296 & 0.212 & 0.008 & 2106 & 18.5 & 17.0 \\
\hline & 1300 & 0.008 & 0.001 & 2639 & 39.0 & 99.5 \\
\hline & 1301 & 0.002 & 0.000 & 2420 & 39.3 & 133.9 \\
\hline & 1302 & 0.018 & 0.002 & 2325 & 35.6 & 97.1 \\
\hline & 1304 & 0.004 & 0.001 & 2036 & 26.1 & 71.0 \\
\hline & 1307 & 0.010 & 0.001 & 2326 & 33.0 & 107.8 \\
\hline & 1310 & 0.020 & 0.002 & 2307 & 27.3 & 40.4 \\
\hline & 1311 & 0.001 & 0.000 & 2222 & 16.8 & 144.9 \\
\hline & 1312 & 0.017 & 0.002 & 2272 & 30.0 & 353.4 \\
\hline & 1313 & 0.033 & 0.003 & 2323 & 30.9 & 117.4 \\
\hline & 1317 & 0.014 & 0.001 & 2207 & 35.7 & 356.3 \\
\hline & 1319 & 0.013 & 0.001 & 2315 & 27.5 & 10.4 \\
\hline & 1320 & 0.007 & 0.001 & 2466 & 23.6 & 93.1 \\
\hline \multirow[t]{2}{*}{ Piegan Glacier } & 1323 & 0.260 & 0.023 & 2512 & 16.4 & 54.3 \\
\hline & 1325 & 0.018 & 0.002 & 2471 & 45.2 & 128.1 \\
\hline \multirow[t]{16}{*}{ Sexton Glacier } & 1329 & 0.352 & 0.032 & 2225 & 24.2 & 76.3 \\
\hline & 1332 & 0.031 & 0.003 & 2348 & 39.3 & 113.4 \\
\hline & 1343 & 0.101 & 0.009 & 2240 & 26.9 & 113.0 \\
\hline & 1352 & 0.073 & 0.007 & 2624 & 41.4 & 36.3 \\
\hline & 1357 & 0.016 & 0.001 & 2399 & 40.5 & 134.3 \\
\hline & 1360 & 0.014 & 0.001 & 2343 & 39.3 & 11.5 \\
\hline & 1362 & 0.119 & 0.011 & 2132 & 23.5 & 56.5 \\
\hline & 1370 & 0.008 & 0.003 & 2210 & 36.8 & 4.0 \\
\hline & 1372 & 0.007 & 0.001 & 2293 & 19.4 & 357.8 \\
\hline & 1374 & 0.009 & 0.001 & 2333 & 22.9 & 152.4 \\
\hline & 1379 & 0.248 & 0.022 & 2340 & 8.0 & 72.4 \\
\hline & 1380 & 0.038 & 0.003 & 2510 & 38.0 & 118.0 \\
\hline & 1381 & 0.002 & 0.001 & 2494 & 36.6 & 3.0 \\
\hline & 1386 & 0.031 & 0.003 & 2373 & 25.8 & 65.4 \\
\hline & 1388 & 0.070 & 0.006 & 2403 & 32.0 & 104.8 \\
\hline & 1389 & 0.009 & 0.001 & 2166 & 29.3 & 109.9 \\
\hline
\end{tabular}




\begin{tabular}{|c|c|c|c|c|c|c|}
\hline Glacier Name & RECNO & $\begin{array}{r}\text { Area } \\
\left(\mathrm{km}^{2}\right)\end{array}$ & $\begin{array}{r}\text { Uncert } \\
\left(\mathbf{k m}^{2}\right)\end{array}$ & $\begin{array}{r}\text { Mean } \\
\text { Elevation }\end{array}$ & Slope & Aspect \\
\hline & 1393 & 0.022 & 0.002 & 2463 & 31.2 & 7.4 \\
\hline & 1394 & 0.005 & 0.000 & 2173 & 29.1 & 111.3 \\
\hline & 1395 & 0.076 & 0.007 & 2284 & 28.6 & 89.6 \\
\hline & 1396 & 0.014 & 0.001 & 2463 & 39.3 & 266.4 \\
\hline & 1397 & 0.017 & 0.002 & 2498 & 31.5 & 64.6 \\
\hline & 1398 & 0.035 & 0.003 & 2192 & 41.5 & 10.2 \\
\hline & 1399 & 0.012 & 0.001 & 2129 & 30.2 & 28.6 \\
\hline & 1400 & 0.006 & 0.001 & 2392 & 36.9 & 140.8 \\
\hline & 1401 & 0.003 & 0.000 & 2488 & 29.9 & 52.5 \\
\hline & 1402 & 0.019 & 0.002 & 2276 & 28.7 & 157.3 \\
\hline & 1403 & 0.027 & 0.008 & 2284 & 22.3 & 297.5 \\
\hline & 1404 & 0.007 & 0.001 & 2010 & 28.8 & 51.0 \\
\hline & 1406 & 0.008 & 0.001 & 2190 & 26.8 & 61.5 \\
\hline & 1407 & 0.010 & 0.001 & 2048 & 19.5 & 66.5 \\
\hline & 1409 & 0.011 & 0.001 & 2255 & 34.7 & 149.1 \\
\hline & 1411 & 0.007 & 0.001 & 2219 & 29.5 & 64.4 \\
\hline & 1413 & 0.075 & 0.003 & 2479 & 45.5 & 6.8 \\
\hline \multirow[t]{5}{*}{ Jackson Glacier } & 1414 & 1.039 & 0.042 & 2180 & 22.9 & 32.9 \\
\hline & 1417 & 0.003 & 0.000 & 2100 & 22.5 & 81.8 \\
\hline & 1419 & 0.081 & 0.003 & 2399 & 31.0 & 322.6 \\
\hline & 1420 & 0.010 & 0.001 & 2075 & 15.9 & 76.1 \\
\hline & 1421 & 0.254 & 0.023 & 2274 & 29.7 & 316.4 \\
\hline \multirow[t]{5}{*}{ Logan Glacier } & 1423 & 0.326 & 0.029 & 2213 & 23.4 & 38.3 \\
\hline & 1424 & 0.185 & 0.007 & 2498 & 30.4 & 323.3 \\
\hline & 1426 & 0.005 & 0.000 & 2337 & 42.2 & 351.0 \\
\hline & 1428 & 0.015 & 0.001 & 2658 & 38.6 & 87.6 \\
\hline & 1429 & 0.021 & 0.002 & 2771 & 30.8 & 85.6 \\
\hline \multirow[t]{12}{*}{ Blackfoot Glacier } & 1430 & 1.567 & 0.063 & 2288 & 16.6 & 20.5 \\
\hline & 1431 & 0.030 & 0.009 & 2418 & 36.6 & 286.4 \\
\hline & 1432 & 0.054 & 0.005 & 2789 & 45.5 & 165.1 \\
\hline & 1433 & 0.008 & 0.001 & 2572 & 43.4 & 107.3 \\
\hline & 1436 & 0.003 & 0.001 & 2286 & 35.0 & 280.3 \\
\hline & 1437 & 0.015 & 0.004 & 2023 & 38.3 & 300.9 \\
\hline & 1439 & 0.008 & 0.001 & 2597 & 46.8 & 168.0 \\
\hline & 1441 & 0.103 & 0.009 & 2434 & 36.5 & 341.4 \\
\hline & 1442 & 0.017 & 0.002 & 2481 & 34.9 & 59.6 \\
\hline & 1443 & 0.359 & 0.032 & 2395 & 21.5 & 117.7 \\
\hline & 1444 & 0.026 & 0.001 & 2502 & 40.6 & 15.0 \\
\hline & 1445 & 0.041 & 0.004 & 2336 & 35.5 & 319.3 \\
\hline
\end{tabular}




\begin{tabular}{|c|c|c|c|c|c|c|}
\hline Glacier Name & RECNO & $\begin{array}{l}\text { Area } \\
\left(\mathrm{km}^{2}\right)\end{array}$ & $\begin{array}{r}\text { Uncert } \\
\left(\mathbf{k m}^{2}\right)\end{array}$ & $\begin{array}{r}\text { Mean } \\
\text { Elevation }\end{array}$ & Slope & Aspect \\
\hline & 1446 & 0.003 & 0.001 & 2289 & 26.6 & 227.5 \\
\hline \multirow[t]{17}{*}{ Red Eagle Glacier } & 1447 & 0.100 & 0.009 & 2156 & 22.1 & 32.2 \\
\hline & 1448 & 0.061 & 0.002 & 2429 & 38.5 & 312.8 \\
\hline & 1449 & 0.009 & 0.001 & 2523 & 32.3 & 350.1 \\
\hline & 1450 & 0.037 & 0.003 & 2223 & 21.1 & 133.5 \\
\hline & 1452 & 0.004 & 0.001 & 2321 & 33.2 & 125.4 \\
\hline & 1453 & 0.009 & 0.001 & 2454 & 35.1 & 170.8 \\
\hline & 1454 & 0.005 & 0.000 & 2245 & 30.5 & 120.0 \\
\hline & 1455 & 0.033 & 0.003 & 2373 & 20.8 & 148.0 \\
\hline & 1456 & 0.005 & 0.000 & 2203 & 24.4 & 158.3 \\
\hline & 1457 & 0.121 & 0.011 & 2418 & 9.6 & 70.9 \\
\hline & 1458 & 0.006 & 0.002 & 2280 & 25.8 & 133.4 \\
\hline & 1459 & 0.007 & 0.001 & 2513 & 34.0 & 92.9 \\
\hline & 1460 & 0.007 & 0.001 & 2312 & 13.5 & 113.8 \\
\hline & 1461 & 0.011 & 0.001 & 2267 & 22.2 & 135.5 \\
\hline & 1462 & 0.016 & 0.001 & 2494 & 15.7 & 226.9 \\
\hline & 1463 & 0.003 & 0.000 & 2260 & 34.6 & 209.9 \\
\hline & 1464 & 0.004 & 0.000 & 2157 & 24.1 & 148.3 \\
\hline \multirow[t]{21}{*}{ Pumpelly Glacier } & 1466 & 0.877 & 0.035 & 2527 & 24.8 & 78.2 \\
\hline & 1468 & 0.017 & 0.002 & 2165 & 23.6 & 64.2 \\
\hline & 1470 & 0.010 & 0.001 & 2055 & 18.0 & 163.3 \\
\hline & 1471 & 0.037 & 0.003 & 2663 & 28.2 & 346.2 \\
\hline & 1472 & 0.079 & 0.007 & 2527 & 29.6 & 333.7 \\
\hline & 1473 & 0.053 & 0.005 & 2157 & 24.4 & 128.2 \\
\hline & 1484 & 0.028 & 0.003 & 2248 & 15.0 & 64.5 \\
\hline & 1485 & 0.015 & 0.001 & 2813 & 42.2 & 103.4 \\
\hline & 1487 & 0.027 & 0.001 & 2481 & 34.8 & 175.3 \\
\hline & 1489 & 0.005 & 0.000 & 2758 & 40.4 & 142.3 \\
\hline & 1490 & 0.015 & 0.001 & 2349 & 33.7 & 48.6 \\
\hline & 1492 & 0.016 & 0.001 & 1905 & 13.8 & 67.4 \\
\hline & 1493 & 0.031 & 0.003 & 2337 & 34.2 & 131.8 \\
\hline & 1494 & 0.031 & 0.003 & 2076 & 23.6 & 150.8 \\
\hline & 1495 & 0.048 & 0.004 & 2173 & 35.4 & 138.3 \\
\hline & 1496 & 0.009 & 0.003 & 1852 & 14.1 & 57.1 \\
\hline & 1498 & 0.003 & 0.000 & 2182 & 26.8 & 108.7 \\
\hline & 1500 & 0.005 & 0.000 & 2171 & 21.3 & 90.4 \\
\hline & 1502 & 0.011 & 0.001 & 2251 & 32.2 & 63.9 \\
\hline & 1503 & 0.014 & 0.001 & 2514 & 30.0 & 86.8 \\
\hline & 1504 & 0.009 & 0.001 & 2398 & 26.2 & 64.1 \\
\hline
\end{tabular}




\begin{tabular}{rrrrrrr}
\hline Glacier Name & RECNO & $\begin{array}{r}\text { Area } \\
\mathbf{( k m}^{\mathbf{2}}\end{array}$ & $\begin{array}{r}\text { Uncert } \\
\mathbf{( k m}^{\mathbf{2}}\end{array}$ & $\begin{array}{r}\text { Mean } \\
\text { Elevation }\end{array}$ & Slope & Aspect \\
\hline \multirow{5}{*}{ Sperry Glacier } & 1505 & 0.009 & 0.001 & 2649 & 18.9 & 77.3 \\
& 1588 & 0.249 & 0.022 & 2420 & 9.7 & 358.1 \\
& 1589 & 0.782 & 0.031 & 2384 & 14.3 & 3.0 \\
& 1590 & 0.025 & 0.007 & 2719 & 26.8 & 121.8 \\
& 1594 & 0.001 & 0.000 & 2407 & 42.9 & 59.1 \\
Harrison Glacier & 1596 & 0.002 & 0.000 & 2424 & 10.3 & 353.7 \\
& 1597 & 0.009 & 0.003 & 2163 & 17.8 & 9.3 \\
& 1598 & 0.008 & 0.002 & 2231 & 44.0 & 328.9 \\
& 1601 & 1.399 & 0.056 & 2492 & 9.5 & 94.7 \\
& 9980 & 0.186 & 0.007 & 2203 & 15.7 & 92.9 \\
& 0.212 & 0.008 & 2212 & 12.7 & 97.3 \\
\hline
\end{tabular}

2015

\begin{tabular}{|c|c|c|c|c|c|c|}
\hline Glacier Name & RECNO & $\begin{array}{l}\text { Area } \\
\left(\mathrm{km}^{2}\right)\end{array}$ & $\begin{array}{l}\text { Uncert } \\
\left(\mathbf{k m}^{2}\right)\end{array}$ & $\begin{array}{l}\text { Mean } \\
\text { Elevation }\end{array}$ & Slope & Aspect \\
\hline & 1004 & 0.029 & 0.002 & 2525 & 32.4 & 115.4 \\
\hline & 1005 & 0.042 & 0.003 & 1993 & 27.9 & 38.5 \\
\hline & 1011 & 0.005 & 0.000 & 2204 & 43.4 & 0.8 \\
\hline & 1012 & 0.016 & 0.001 & 2411 & 30.5 & 38.7 \\
\hline \multirow[t]{6}{*}{ Herbst Glacier } & 1013 & 0.032 & 0.002 & 2214 & 31.7 & 57.2 \\
\hline & 1015 & 0.013 & 0.001 & 2432 & 35.7 & 39.9 \\
\hline & 1016 & 0.006 & 0.000 & 2555 & 37.2 & 38.4 \\
\hline & 1017 & 0.023 & 0.002 & 2292 & 57.2 & 339.4 \\
\hline & 1021 & 0.108 & 0.008 & 1724 & 20.7 & 45.9 \\
\hline & 1024 & 0.052 & 0.004 & 2285 & 31.9 & 0.3 \\
\hline \multirow[t]{2}{*}{ Hudson Glacier } & 1029 & 0.052 & 0.004 & 2175 & 38.9 & 4.6 \\
\hline & 1036 & 0.006 & 0.000 & 2343 & 47.1 & 12.0 \\
\hline \multirow[t]{8}{*}{ Boulder Glacier } & 1041 & 0.043 & 0.003 & 2422 & 34.8 & 19.9 \\
\hline & 1042 & 0.015 & 0.001 & 2524 & 29.8 & 340.7 \\
\hline & 1044 & 0.034 & 0.002 & 1973 & 25.2 & 46.2 \\
\hline & 1052 & 0.015 & 0.001 & 2078 & 23.2 & 68.8 \\
\hline & 1054 & 0.002 & 0.000 & 2147 & 42.1 & 352.2 \\
\hline & 1055 & 0.991 & 0.069 & 2380 & 17.7 & 83.0 \\
\hline & 1059 & 0.010 & 0.001 & 2083 & 24.6 & 355.8 \\
\hline & 1060 & 0.139 & 0.010 & 2148 & 28.4 & 35.5 \\
\hline
\end{tabular}




\begin{tabular}{|c|c|c|c|c|c|c|}
\hline Glacier Name & RECNO & $\begin{array}{l}\text { Area } \\
\left(\mathbf{k m}^{2}\right)\end{array}$ & $\begin{array}{l}\text { Uncert } \\
\left(\mathbf{k m}^{2}\right)\end{array}$ & $\begin{array}{l}\text { Mean } \\
\text { Elevation }\end{array}$ & Slope & Aspect \\
\hline & 1065 & 0.003 & 0.000 & 2221 & 44.8 & 13.0 \\
\hline & 1066 & 0.004 & 0.000 & 2230 & 38.5 & 325.2 \\
\hline & 1067 & 0.002 & 0.000 & 2362 & 17.2 & 300.9 \\
\hline & 1068 & 0.069 & 0.005 & 2193 & 29.1 & 344.0 \\
\hline & 1069 & 0.011 & 0.001 & 2128 & 46.0 & 335.4 \\
\hline & 1072 & 0.878 & 0.061 & 2541 & 11.5 & 14.8 \\
\hline & 1073 & 0.136 & 0.010 & 2598 & 32.5 & 338.8 \\
\hline \multirow[t]{10}{*}{ Miche Waburn } & 1074 & 0.104 & 0.007 & 2229 & 23.7 & 15.5 \\
\hline & 1075 & 0.003 & 0.000 & 2216 & 43.0 & 22.9 \\
\hline & 1077 & 0.021 & 0.001 & 2267 & 42.7 & 324.5 \\
\hline & 1079 & 0.018 & 0.001 & 2387 & 30.9 & 15.9 \\
\hline & 1081 & 0.045 & 0.003 & 2282 & 31.0 & 323.9 \\
\hline & 1082 & 0.002 & 0.000 & 2513 & 34.7 & 8.8 \\
\hline & 1084 & 0.117 & 0.008 & 2644 & 33.7 & 56.2 \\
\hline & 1085 & 0.022 & 0.002 & 2204 & 26.8 & 70.7 \\
\hline & 1086 & 0.017 & 0.001 & 2683 & 38.0 & 98.4 \\
\hline & 1088 & 0.058 & 0.004 & 2233 & 53.9 & 332.9 \\
\hline \multirow[t]{4}{*}{ Thunderbird Glacier } & 1089 & 0.118 & 0.008 & 2295 & 22.5 & 42.7 \\
\hline & 1090 & 0.001 & 0.000 & 2440 & 50.0 & 85.2 \\
\hline & 1091 & 0.069 & 0.005 & 2419 & 35.3 & 76.1 \\
\hline & 1093 & 0.023 & 0.002 & 2416 & 41.4 & 352.5 \\
\hline \multirow[t]{14}{*}{ Dixon Glacier } & 1094 & 0.132 & 0.009 & 2302 & 21.8 & 18.3 \\
\hline & 1095 & 0.021 & 0.001 & 2232 & 33.6 & 308.5 \\
\hline & 1096 & 0.014 & 0.001 & 2394 & 38.6 & 335.8 \\
\hline & 1097 & 0.046 & 0.003 & 1902 & 34.9 & 98.9 \\
\hline & 1098 & 0.009 & 0.001 & 2060 & 42.8 & 353.3 \\
\hline & 1099 & 0.005 & 0.000 & 2026 & 33.7 & 270.1 \\
\hline & 1102 & 0.034 & 0.002 & 1966 & 35.2 & 304.9 \\
\hline & 1103 & 0.003 & 0.000 & 2055 & 49.1 & 310.9 \\
\hline & 1104 & 0.013 & 0.001 & 2902 & 44.5 & 107.1 \\
\hline & 1105 & 0.014 & 0.001 & 2563 & 32.7 & 120.4 \\
\hline & 1106 & 0.008 & 0.001 & 3116 & 51.3 & 110.6 \\
\hline & 1108 & 0.048 & 0.003 & 2115 & 25.9 & 136.3 \\
\hline & 1114 & 0.007 & 0.000 & 2262 & 35.5 & 114.5 \\
\hline & 1115 & 0.017 & 0.001 & 2067 & 34.8 & 106.5 \\
\hline \multirow[t]{4}{*}{ Whitecrow Glacier } & 1118 & 0.107 & 0.007 & 2159 & 41.8 & 93.2 \\
\hline & 1120 & 0.076 & 0.005 & 2075 & 20.1 & 59.1 \\
\hline & 1122 & 0.012 & 0.001 & 2139 & 28.2 & 161.4 \\
\hline & 1123 & 0.002 & 0.000 & 2358 & 25.8 & 84.4 \\
\hline
\end{tabular}




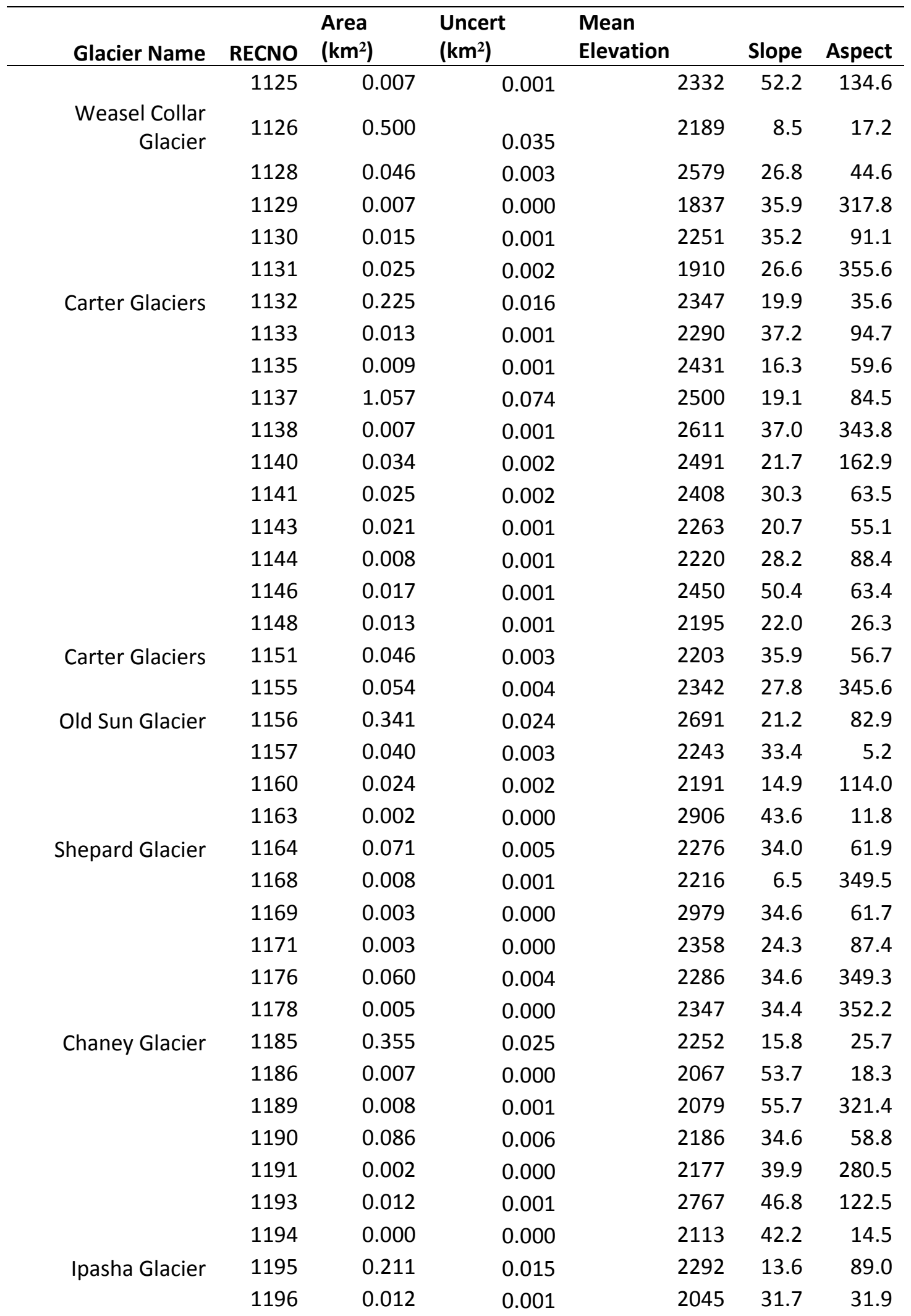




\begin{tabular}{|c|c|c|c|c|c|c|}
\hline Glacier Name & RECNO & $\begin{array}{l}\text { Area } \\
\left(\mathbf{k m}^{2}\right)\end{array}$ & $\begin{array}{l}\text { Uncert } \\
\left(\mathbf{k m}^{2}\right)\end{array}$ & $\begin{array}{l}\text { Mean } \\
\text { Elevation }\end{array}$ & Slope & Aspect \\
\hline & 1197 & 0.002 & 0.000 & 2018 & 36.8 & 331.3 \\
\hline & 1199 & 0.023 & 0.002 & 2579 & 46.0 & 308.4 \\
\hline & 1200 & 0.000 & 0.000 & 2106 & 42.5 & 343.2 \\
\hline Two Ocean Glacier & 1201 & 0.250 & 0.017 & 2617 & 25.4 & 77.0 \\
\hline \multirow[t]{10}{*}{ Ahern Glacier } & 1202 & 0.512 & 0.036 & 2490 & 12.0 & 84.9 \\
\hline & 1203 & 0.008 & 0.001 & 2201 & 38.8 & 143.1 \\
\hline & 1204 & 0.002 & 0.000 & 2681 & 41.2 & 108.0 \\
\hline & 1208 & 0.003 & 0.000 & 2397 & 40.3 & 314.2 \\
\hline & 1210 & 0.006 & 0.000 & 2659 & 35.4 & 72.7 \\
\hline & 1212 & 0.002 & 0.000 & 2352 & 25.6 & 58.8 \\
\hline & 1216 & 0.003 & 0.000 & 2564 & 30.5 & 134.3 \\
\hline & 1218 & 0.003 & 0.000 & 2545 & 32.4 & 185.4 \\
\hline & 1219 & 0.019 & 0.001 & 2484 & 20.6 & 45.6 \\
\hline & 1222 & 0.006 & 0.000 & 2461 & 17.0 & 106.1 \\
\hline \multirow[t]{18}{*}{ Vulture Glacier } & 1224 & 0.297 & 0.021 & 2594 & 26.6 & 60.9 \\
\hline & 1227 & 0.078 & 0.005 & 1788 & 32.0 & 58.1 \\
\hline & 1229 & 0.032 & 0.002 & 2707 & 34.0 & 150.5 \\
\hline & 1230 & 0.002 & 0.000 & 2222 & 28.2 & 125.2 \\
\hline & 1231 & 0.037 & 0.003 & 1727 & 19.9 & 19.8 \\
\hline & 1236 & 0.002 & 0.000 & 2282 & 32.5 & 147.3 \\
\hline & 1238 & 0.017 & 0.001 & 2088 & 48.4 & 335.9 \\
\hline & 1239 & 0.005 & 0.000 & 2020 & 32.9 & 138.3 \\
\hline & 1240 & 0.025 & 0.002 & 1859 & 0.0 & 249.2 \\
\hline & 1243 & 0.006 & 0.000 & 2092 & 44.9 & 125.7 \\
\hline & 1246 & 0.019 & 0.001 & 2024 & 48.2 & 72.6 \\
\hline & 1250 & 0.018 & 0.001 & 2205 & 21.0 & 96.4 \\
\hline & 1253 & 0.053 & 0.004 & 2183 & 28.8 & 31.1 \\
\hline & 1254 & 0.032 & 0.002 & 2101 & 37.4 & 18.7 \\
\hline & 1255 & 0.010 & 0.001 & 2390 & 43.2 & 50.2 \\
\hline & 1256 & 0.017 & 0.001 & 1978 & 27.8 & 16.0 \\
\hline & 1257 & 0.020 & 0.001 & 2254 & 22.4 & 91.4 \\
\hline & 1258 & 0.016 & 0.001 & 2173 & 15.5 & 45.4 \\
\hline \multirow[t]{3}{*}{ Swiftcurrent Glacier } & 1259 & 0.172 & 0.012 & 2214 & 18.8 & 11.2 \\
\hline & 1260 & 0.006 & 0.000 & 2250 & 26.9 & 7.7 \\
\hline & 1261 & 0.045 & 0.003 & 2202 & 28.2 & 343.3 \\
\hline Salamander Glacier & 1271 & 0.176 & 0.012 & 2200 & 22.5 & 100.9 \\
\hline \multirow[t]{2}{*}{ Grinnell Glacier } & 1277 & 0.564 & 0.039 & 2054 & 7.9 & 7.0 \\
\hline & 1281 & 0.007 & 0.001 & 2021 & 22.4 & 277.0 \\
\hline Gem Glacier & 1283 & 0.022 & 0.002 & 2509 & 42.8 & 36.1 \\
\hline
\end{tabular}




\begin{tabular}{|c|c|c|c|c|c|c|}
\hline Glacier Name & RECNO & $\begin{array}{l}\text { Area } \\
\left(\mathbf{k m}^{2}\right)\end{array}$ & $\begin{array}{l}\text { Uncert } \\
\left(\mathbf{k m}^{2}\right)\end{array}$ & $\begin{array}{l}\text { Mean } \\
\text { Elevation }\end{array}$ & Slope & Aspect \\
\hline & 1284 & 0.066 & 0.005 & 2016 & 15.7 & 85.8 \\
\hline & 1285 & 0.043 & 0.003 & 1975 & 34.1 & 322.6 \\
\hline & 1286 & 0.011 & 0.001 & 2145 & 33.7 & 91.7 \\
\hline & 1287 & 0.020 & 0.001 & 2646 & 42.4 & 356.7 \\
\hline & 1288 & 0.042 & 0.003 & 1737 & 34.8 & 97.8 \\
\hline & 1291 & 0.071 & 0.005 & 2166 & 19.4 & 90.9 \\
\hline \multirow[t]{13}{*}{ Siyeh Glacier } & 1296 & 0.232 & 0.016 & 2060 & 20.7 & 13.3 \\
\hline & 1300 & 0.004 & 0.000 & 2624 & 36.2 & 91.0 \\
\hline & 1301 & 0.002 & 0.000 & 2420 & 39.3 & 133.9 \\
\hline & 1302 & 0.012 & 0.001 & 2299 & 33.2 & 96.9 \\
\hline & 1304 & 0.006 & 0.000 & 2034 & 26.0 & 66.4 \\
\hline & 1307 & 0.003 & 0.000 & 2353 & 43.3 & 102.6 \\
\hline & 1310 & 0.014 & 0.001 & 2320 & 36.1 & 37.4 \\
\hline & 1311 & 0.001 & 0.000 & 2224 & 21.2 & 128.9 \\
\hline & 1312 & 0.018 & 0.001 & 2260 & 19.4 & 354.3 \\
\hline & 1313 & 0.032 & 0.002 & 2358 & 5.8 & 91.6 \\
\hline & 1317 & 0.014 & 0.001 & 2201 & 32.4 & 357.7 \\
\hline & 1319 & 0.016 & 0.001 & 2320 & 30.1 & 12.8 \\
\hline & 1320 & 0.008 & 0.001 & 2466 & 24.8 & 92.6 \\
\hline \multirow[t]{2}{*}{ Piegan Glacier } & 1323 & 0.246 & 0.017 & 2519 & 17.0 & 57.1 \\
\hline & 1325 & 0.015 & 0.001 & 2502 & 53.8 & 124.9 \\
\hline \multirow[t]{18}{*}{ Sexton Glacier } & 1329 & 0.299 & 0.021 & 2209 & 23.7 & 64.5 \\
\hline & 1332 & 0.028 & 0.002 & 2347 & 40.8 & 110.5 \\
\hline & 1343 & 0.066 & 0.005 & 2264 & 26.7 & 103.1 \\
\hline & 1347 & 0.034 & 0.002 & 2322 & 52.5 & 344.8 \\
\hline & 1352 & 0.071 & 0.005 & 2714 & 31.1 & 73.4 \\
\hline & 1356 & 0.006 & 0.000 & 2406 & 30.7 & 16.5 \\
\hline & 1357 & 0.016 & 0.001 & 2416 & 48.8 & 132.1 \\
\hline & 1360 & 0.010 & 0.001 & 2358 & 45.0 & 10.9 \\
\hline & 1362 & 0.082 & 0.006 & 2121 & 24.5 & 74.6 \\
\hline & 1363 & 0.003 & 0.000 & 1887 & 42.4 & 7.6 \\
\hline & 1367 & 0.007 & 0.000 & 2393 & 27.7 & 7.5 \\
\hline & 1368 & 0.003 & 0.000 & 2516 & 35.2 & 54.1 \\
\hline & 1370 & 0.003 & 0.000 & 2210 & 36.8 & 4.0 \\
\hline & 1372 & 0.007 & 0.001 & 2309 & 20.6 & 351.2 \\
\hline & 1374 & 0.002 & 0.000 & 2324 & 18.2 & 142.0 \\
\hline & 1379 & 0.219 & 0.015 & 2350 & 14.5 & 89.5 \\
\hline & 1380 & 0.022 & 0.002 & 2495 & 31.1 & 153.7 \\
\hline & 1381 & 0.002 & 0.000 & 2488 & 38.8 & 12.9 \\
\hline
\end{tabular}




\begin{tabular}{|c|c|c|c|c|c|c|}
\hline Glacier Name & RECNO & $\begin{array}{l}\text { Area } \\
\left(\mathbf{k m}^{2}\right)\end{array}$ & $\begin{array}{l}\text { Uncert } \\
\left(\mathbf{k m}^{2}\right)\end{array}$ & $\begin{array}{l}\text { Mean } \\
\text { Elevation }\end{array}$ & Slope & Aspect \\
\hline & 1386 & 0.021 & 0.001 & 2377 & 25.1 & 62.8 \\
\hline & 1388 & 0.054 & 0.004 & 2412 & 33.3 & 110.1 \\
\hline & 1389 & 0.007 & 0.001 & 2172 & 31.4 & 113.7 \\
\hline & 1393 & 0.022 & 0.002 & 2499 & 34.7 & 11.2 \\
\hline & 1394 & 0.001 & 0.000 & 2173 & 29.1 & 111.3 \\
\hline & 1395 & 0.039 & 0.003 & 2293 & 23.0 & 90.3 \\
\hline & 1396 & 0.010 & 0.001 & 2463 & 39.3 & 266.4 \\
\hline & 1397 & 0.009 & 0.001 & 2503 & 29.3 & 63.1 \\
\hline & 1398 & 0.024 & 0.002 & 2278 & 32.4 & 24.9 \\
\hline & 1399 & 0.008 & 0.001 & 2129 & 30.2 & 28.6 \\
\hline & 1400 & 0.005 & 0.000 & 2392 & 36.9 & 140.8 \\
\hline & 1401 & 0.005 & 0.000 & 2498 & 16.4 & 59.4 \\
\hline & 1402 & 0.018 & 0.001 & 2282 & 29.1 & 153.2 \\
\hline & 1403 & 0.019 & 0.001 & 2291 & 25.2 & 288.4 \\
\hline & 1404 & 0.001 & 0.000 & 2007 & 28.4 & 51.7 \\
\hline & 1406 & 0.005 & 0.000 & 2194 & 26.7 & 62.0 \\
\hline & 1407 & 0.004 & 0.000 & 2054 & 28.1 & 74.8 \\
\hline & 1409 & 0.009 & 0.001 & 2258 & 32.2 & 144.6 \\
\hline & 1411 & 0.001 & 0.000 & 2213 & 32.7 & 69.1 \\
\hline & 1413 & 0.061 & 0.004 & 2512 & 43.2 & 0.4 \\
\hline \multirow[t]{5}{*}{ Jackson Glacier } & 1414 & 0.935 & 0.065 & 2227 & 15.3 & 80.4 \\
\hline & 1417 & 0.002 & 0.000 & 2101 & 25.9 & 78.7 \\
\hline & 1419 & 0.079 & 0.006 & 2394 & 30.1 & 325.0 \\
\hline & 1420 & 0.003 & 0.000 & 2057 & 18.7 & 85.0 \\
\hline & 1421 & 0.210 & 0.015 & 2459 & 38.2 & 309.3 \\
\hline \multirow[t]{5}{*}{ Logan Glacier } & 1423 & 0.219 & 0.015 & 2208 & 14.2 & 74.4 \\
\hline & 1424 & 0.149 & 0.010 & 2546 & 46.6 & 340.0 \\
\hline & 1426 & 0.000 & 0.000 & 2359 & 40.0 & 353.8 \\
\hline & 1428 & 0.013 & 0.001 & 2651 & 43.2 & 90.7 \\
\hline & 1429 & 0.024 & 0.002 & 2778 & 37.6 & 86.7 \\
\hline \multirow[t]{9}{*}{ Blackfoot Glacier } & 1430 & 1.522 & 0.107 & 2298 & 18.1 & 19.1 \\
\hline & 1431 & 0.024 & 0.002 & 2417 & 35.5 & 286.1 \\
\hline & 1432 & 0.049 & 0.003 & 2774 & 39.8 & 162.3 \\
\hline & 1433 & 0.013 & 0.001 & 2565 & 41.0 & 103.5 \\
\hline & 1436 & 0.002 & 0.000 & 2280 & 33.9 & 279.7 \\
\hline & 1437 & 0.005 & 0.000 & 2041 & 38.2 & 299.6 \\
\hline & 1439 & 0.007 & 0.000 & 2613 & 46.2 & 169.5 \\
\hline & 1441 & 0.092 & 0.006 & 2461 & 35.4 & 341.2 \\
\hline & 1442 & 0.013 & 0.001 & 2474 & 31.7 & 64.8 \\
\hline
\end{tabular}




\begin{tabular}{|c|c|c|c|c|c|c|}
\hline Glacier Name & RECNO & $\begin{array}{l}\text { Area } \\
\left(\mathbf{k m}^{2}\right)\end{array}$ & $\begin{array}{l}\text { Uncert } \\
\left(\mathbf{k m}^{2}\right)\end{array}$ & $\begin{array}{l}\text { Mean } \\
\text { Elevation }\end{array}$ & Slope & Aspect \\
\hline & 1443 & 0.323 & 0.023 & 2440 & 30.7 & 136.2 \\
\hline & 1444 & 0.022 & 0.002 & 2549 & 27.0 & 2.0 \\
\hline & 1445 & 0.034 & 0.002 & 2345 & 38.7 & 320.0 \\
\hline & 1446 & 0.002 & 0.000 & 2297 & 26.8 & 203.7 \\
\hline \multirow[t]{17}{*}{ Red Eagle Glacier } & 1447 & 0.080 & 0.006 & 2177 & 29.7 & 33.1 \\
\hline & 1448 & 0.051 & 0.004 & 2428 & 37.7 & 313.3 \\
\hline & 1449 & 0.009 & 0.001 & 2527 & 30.7 & 349.8 \\
\hline & 1450 & 0.017 & 0.001 & 2230 & 19.8 & 161.2 \\
\hline & 1452 & 0.001 & 0.000 & 2330 & 31.2 & 120.7 \\
\hline & 1453 & 0.005 & 0.000 & 2449 & 41.8 & 169.9 \\
\hline & 1454 & 0.001 & 0.000 & 2272 & 33.8 & 113.6 \\
\hline & 1455 & 0.025 & 0.002 & 2392 & 27.6 & 146.1 \\
\hline & 1456 & 0.003 & 0.000 & 2202 & 21.3 & 162.4 \\
\hline & 1457 & 0.103 & 0.007 & 2408 & 13.7 & 162.0 \\
\hline & 1458 & 0.004 & 0.000 & 2292 & 23.4 & 142.7 \\
\hline & 1459 & 0.002 & 0.000 & 2526 & 35.3 & 98.7 \\
\hline & 1460 & 0.005 & 0.000 & 2312 & 13.5 & 108.6 \\
\hline & 1461 & 0.002 & 0.000 & 2272 & 19.1 & 137.9 \\
\hline & 1462 & 0.005 & 0.000 & 2502 & 20.2 & 186.7 \\
\hline & 1463 & 0.001 & 0.000 & 2276 & 35.2 & 196.5 \\
\hline & 1464 & 0.000 & 0.000 & 2159 & 25.2 & 137.3 \\
\hline \multirow[t]{18}{*}{ Pumpelly Glacier } & 1466 & 0.913 & 0.064 & 2568 & 18.5 & 79.2 \\
\hline & 1468 & 0.018 & 0.001 & 2167 & 19.7 & 62.0 \\
\hline & 1470 & 0.005 & 0.000 & 2062 & 18.7 & 167.0 \\
\hline & 1472 & 0.044 & 0.003 & 2571 & 36.8 & 322.8 \\
\hline & 1473 & 0.038 & 0.003 & 2170 & 25.1 & 127.4 \\
\hline & 1484 & 0.013 & 0.001 & 2257 & 18.1 & 71.1 \\
\hline & 1485 & 0.012 & 0.001 & 2833 & 39.4 & 98.7 \\
\hline & 1487 & 0.028 & 0.002 & 2558 & 45.3 & 118.2 \\
\hline & 1489 & 0.007 & 0.000 & 2769 & 50.1 & 156.8 \\
\hline & 1490 & 0.008 & 0.001 & 2346 & 31.2 & 49.6 \\
\hline & 1492 & 0.010 & 0.001 & 1917 & 16.4 & 91.1 \\
\hline & 1493 & 0.024 & 0.002 & 2345 & 30.1 & 137.8 \\
\hline & 1494 & 0.030 & 0.002 & 2092 & 26.5 & 153.5 \\
\hline & 1495 & 0.026 & 0.002 & 2186 & 34.6 & 136.5 \\
\hline & 1496 & 0.005 & 0.000 & 1852 & 10.7 & 67.3 \\
\hline & 1498 & 0.002 & 0.000 & 2185 & 25.1 & 114.6 \\
\hline & 1500 & 0.002 & 0.000 & 2162 & 19.2 & 84.4 \\
\hline & 1502 & 0.008 & 0.001 & 2257 & 33.5 & 66.5 \\
\hline
\end{tabular}




\begin{tabular}{|c|c|c|c|c|c|c|}
\hline Glacier Name & RECNO & $\begin{array}{l}\text { Area } \\
\left(\mathrm{km}^{2}\right)\end{array}$ & $\begin{array}{l}\text { Uncert } \\
\left(\mathrm{km}^{2}\right)\end{array}$ & $\begin{array}{l}\text { Mean } \\
\text { Elevation }\end{array}$ & Slope & Aspect \\
\hline \multirow{10}{*}{ Sperry Glacier } & 1503 & 0.009 & 0.001 & 2519 & 32.1 & 91.4 \\
\hline & 1504 & 0.008 & 0.001 & 2402 & 26.4 & 66.4 \\
\hline & 1505 & 0.009 & 0.001 & 2655 & 19.5 & 81.9 \\
\hline & 1584 & 0.002 & 0.000 & 2189 & 26.1 & 156.6 \\
\hline & 1588 & 0.257 & 0.018 & 2443 & 14.9 & 345.5 \\
\hline & 1589 & 0.813 & 0.057 & 2441 & 15.5 & 355.4 \\
\hline & 1592 & 0.286 & 0.020 & 2486 & 30.9 & 58.4 \\
\hline & 1593 & 0.279 & 0.020 & 2402 & 20.9 & 78.6 \\
\hline & 1594 & 0.000 & 0.000 & 2401 & 43.4 & 45.2 \\
\hline & 1596 & 0.001 & 0.000 & 2426 & 9.4 & 6.3 \\
\hline \multirow{5}{*}{ Harrison Glacier } & 1597 & 0.007 & 0.001 & 2155 & 17.0 & 0.7 \\
\hline & 1598 & 0.008 & 0.001 & 2194 & 29.2 & 344.9 \\
\hline & 1601 & 1.344 & 0.094 & 2526 & 17.5 & 162.7 \\
\hline & 1602 & 0.179 & 0.013 & 2208 & 15.7 & 97.6 \\
\hline & 9980 & 0.168 & 0.012 & 2214 & 12.7 & 97.3 \\
\hline
\end{tabular}

